Portland State University

PDXScholar

$5-14-1968$

\title{
Children's Drama Available for the Elementary School Children of Portland, Oregon
}

Margaret Othus Gender

Portland State University

Follow this and additional works at: https://pdxscholar.library.pdx.edu/open_access_etds

Part of the Art Education Commons, and the Theatre and Performance Studies Commons Let us know how access to this document benefits you.

Recommended Citation

Gender, Margaret Othus, "Children's Drama Available for the Elementary School Children of Portland, Oregon" (1968). Dissertations and Theses. Paper 483.

https://doi.org/10.15760/etd.483

This Thesis is brought to you for free and open access. It has been accepted for inclusion in Dissertations and Theses by an authorized administrator of PDXScholar. Please contact us if we can make this document more accessible: pdxscholar@pdx.edu. 
Margaret O Gender

(knate of oident)
Nox the Master of Science in Teaching (togrea)
11...... Theater. Arts (Major)
Sept. 7,1967

(bate)

rth 1e $5 . . . .$. Children's. Drama Available For the Elementary School Children

...of Portland, Oregon $\ldots \ldots \ldots \ldots \ldots \ldots \ldots \ldots \ldots \ldots \ldots \ldots \ldots \ldots \ldots \ldots \ldots \ldots$ Abstract approved: .

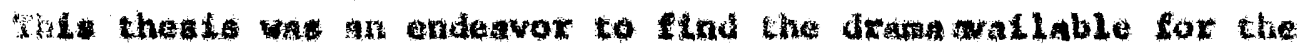
elcmentary children of Porcland, Oregoa. In dectulng whe drama was

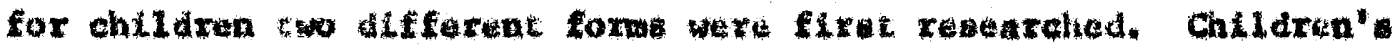

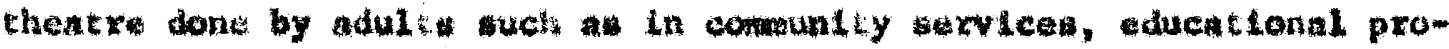

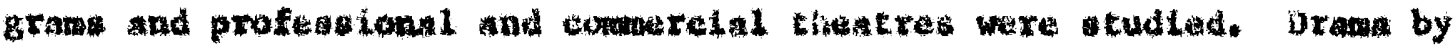
chlidren, raferred to wo the lom forrallized drime, creakive dramatice

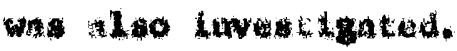

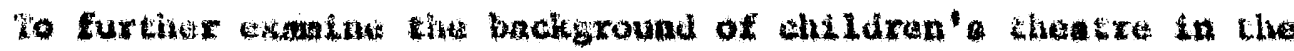
Waitud states, varlodis ehllaren' heacres around the councry were

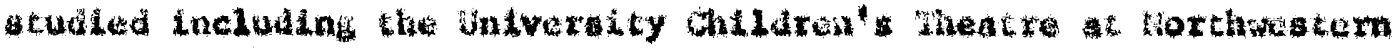

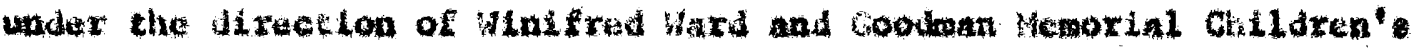

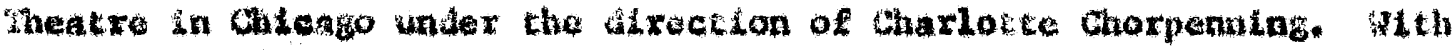
the advent of the oducational field into ohildren's theatre culminating 
wh the chlldren' Theatre Conference the movement became wide spread throughout the Untted States. A great deal has been done to spark chlldren's drama not only in the viewing of children's plays in production but affording children actual participation in creative drama workhops and children's productions. More and more community theatres, commercial groups and univeratties are doing children"s drame throughout the nation.

In an effort to flnd wat was being offered to the Portland chlldren in dxama, the Portland Public Grade Schools were first approached. Whth the help of the Language Arts supervisor five areas of drame for chlldren were researched through reading and interviews. Although the Portland Public Grade Schools have no drame course inetrueted by speciflc drama teachers they do encourage drame to be correlated into the classroom program and taught in "in service" courses for thelr teachers. The "model school program" has drawa as a definite course and the Portland schools offer a sumer school which has a creative drama course avallable to the elementary school chlldren.

The Untversity of Portland, Catholic univerifing In Portland, has achieved the most definite progres in the Portland area in children's theatre. They not only produce children's plays during the school year but offer creative drama and playwriting in their course of study. Under the instruction and production of Mra. Catherine Roberts for the last six years they are striving to bring children's theatre to the Portiand children and their teachere.

Portland does offer some excellent theatre for children in the communtty. The Portland Juntor League, a service group, has nationally 
been imolved throughout the years with thatr chlldren's play productions" by their groups for the achool children of thelr communites. Now, after turning their productions over to Portland Univeraity they still malntain a very worthwile progran of puppetry for the achool chlldren of Portland. Portland Jualor Civle theatre, one of the oldest chlldren's thatre groups in Portland, not only produce chlldren's productions by children but conduets chl1dxan's drane school throughout the year. The Portland Park Bureau also takes an active part particularly during the ougan in children's drame and training. The neweet to Portland to the Playmakex's Growp, relatively young but eagar in its endeavor for the ehildren of the area. Their efforta include both productions and shooling on creative

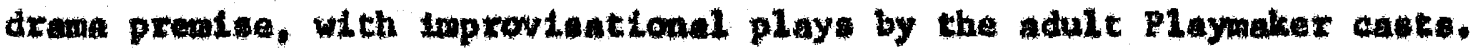
Children"s theatre in Portland is developtng but has faced many problems and has many more to mumount. The progreas of the active workers in this movenent show hope for the future for the children of Doxtland.

The appandix of the thesis is devoted to several programs involved with the tanching of drans. Fint is a courat in creative drame offered to college students in the colloge and ualvarelthas having such coursea in thatr currlculum. A creative drama course correlated with the ragular classroos subjects in the Portland Grade school curriculum is also Included. Last, aumer gehool plan for commulty theatre ia shown.

A11 the arts combine in the theatre, decor, the dance, impereonation, effective opeech, the uong, pantomime, the projection of peraonality, the art of aupressing nelf and even 111 will, for the untty of effort. 
Hundreds of other arte could be listed Including the art of living together and the art of creartve Inegimation. That to why the play can never be onitted from child ducation. 


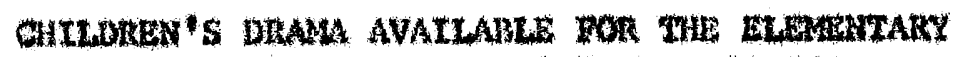

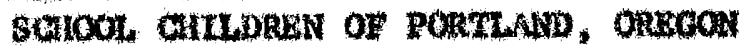

\author{
A THESIS

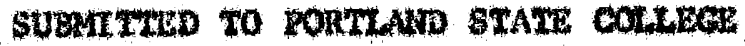

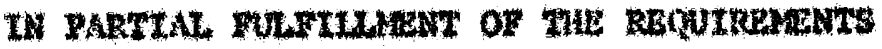 \\ TOR THe Drenere on \\ WATER OF SCTENCE TN TEACHuE
}

iy

Margance Othus Gendor

Juty 1967

PORTLAND STATE COLLEGE

LIBRARY 


\section{APRROVED:}

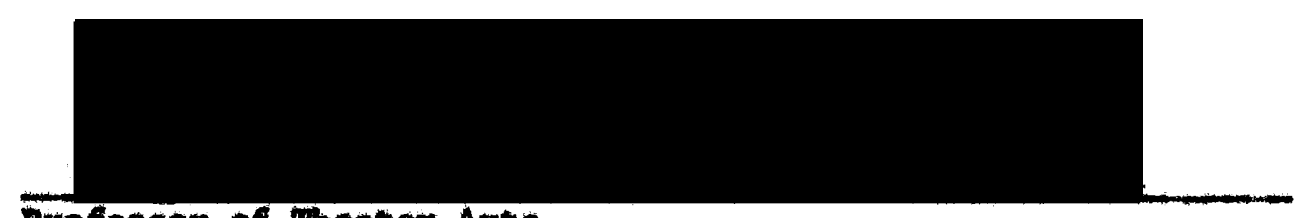

Profeseor of Theater Axte
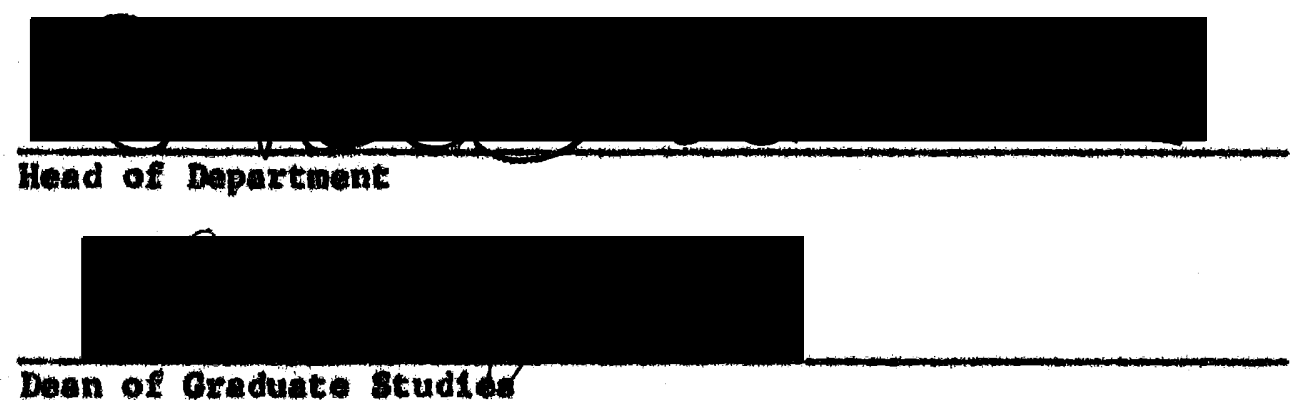

Deen of Greduite Studid

Date thesl is Presented May 14, 1968

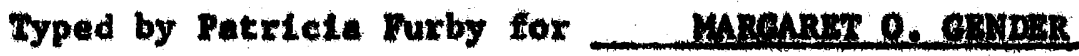


Tame of cowrants

chapkex

Page

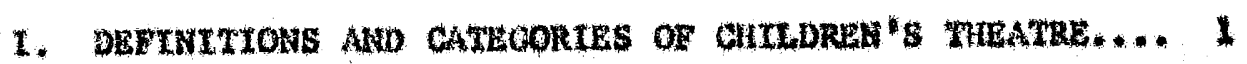

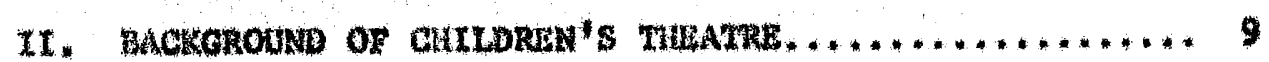

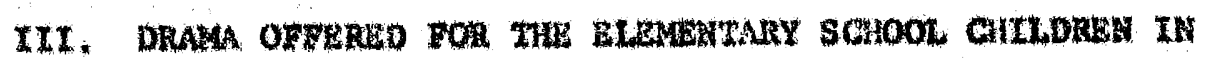

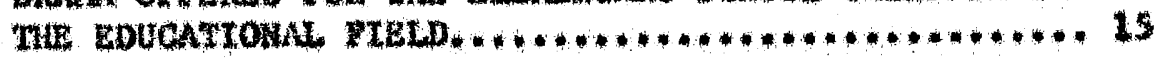

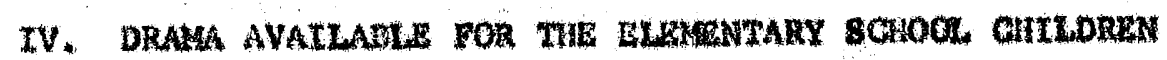

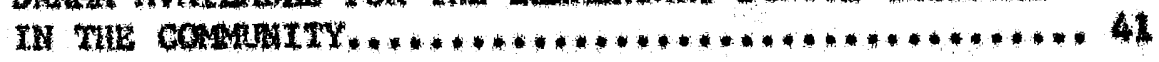
BTHETORARU 60 Appanorx 


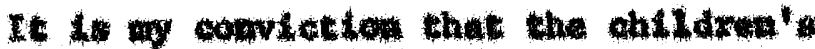
nhedtro is ane of the visy, very great Hwontions of the 20th wontury, and that 16. 4 of vant adweationd value.....

It It mud the moot afoctive tmach of worall and pxomoter of qoed sonduet thet

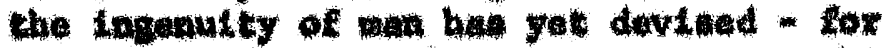

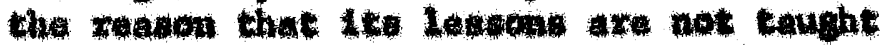
wondly by the book and draxy howily, but by HLLble and enthudur action and they

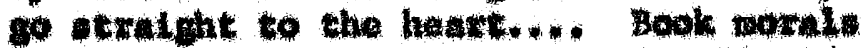
ofted get no further than the tritellatet but when hey travel trow ohlldrank theatre - they do not stop permenently at

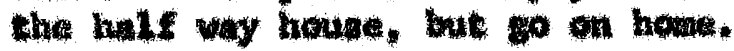

Maxtc Twain 


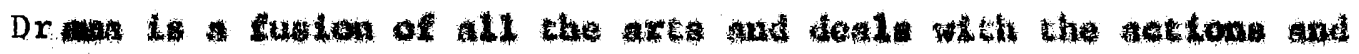

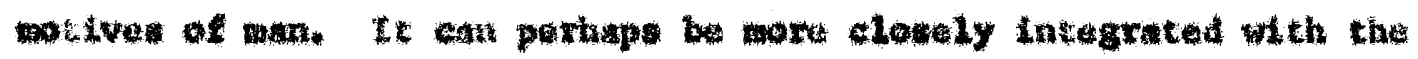

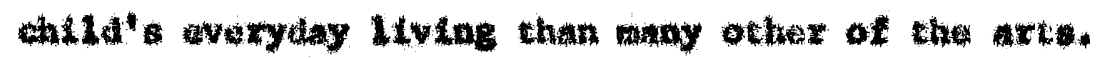

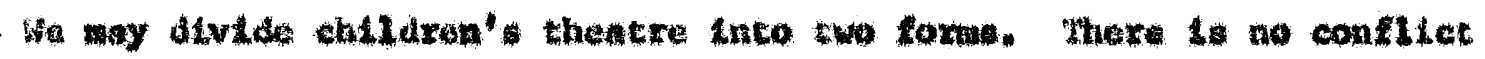

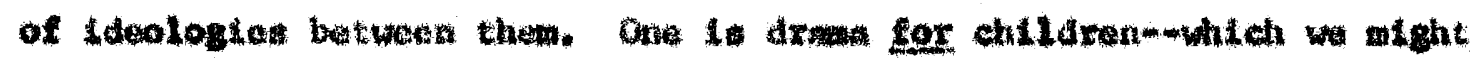

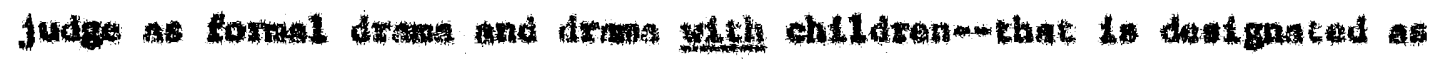

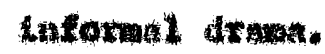

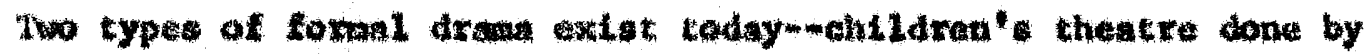
adules and chlldre thentre sone by chlldron. Chlidren's heatro

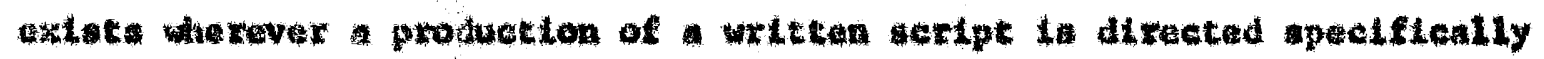
for the chlla adfenes. Ang activity hich does not prowlde the child

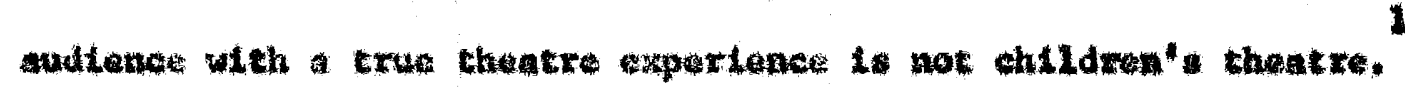
The value of both forme for tho actor Involved must be acondary

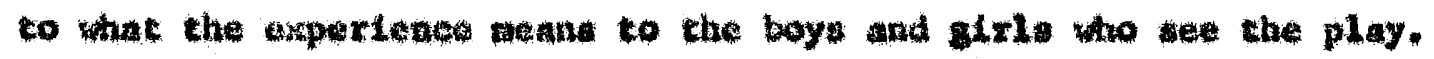
The aveces of tho production ts judged by the foy and the culcural

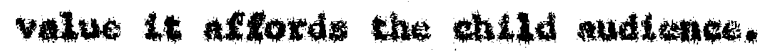

\section{1}

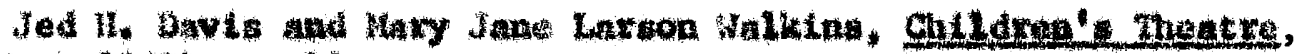
(tives tork 1960), 12 . 
Dollefs and objectives of present day ehllaran' thatre wet forth by the chlldren"e thentre conterence are:

1. Theatre giver boy and girls the joy of ceotng good atortas cand Rilve on the strige.

2. Higher tandaxds of taste: can be developed in children alinee taste always improves with true art exportence.

3. Huan expartance child sed on the atage wil holp him grow In the underatandigg and apprestathon of ILfo valueg.

4. A good chlldren's thatre w11 bulld in chlldran basts for becoming diecrtutinating adult audience of the futura.

Childran* theatre produced by adult groups are divided inco throe main types Cowanity servico, ecucational, profosalonal comarclal. In the Jalted states; wore than 1,200 units, Largely anterur, produced from one to four plays annualiy for children. More and woxe communtty groups, $200 \mathrm{high}$ chools, and at leate 220 colleges 3 are protuctig.

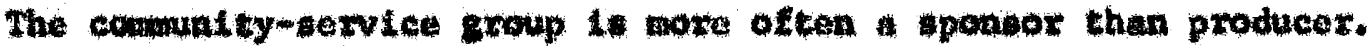

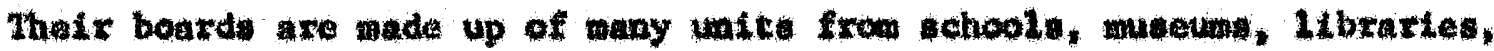

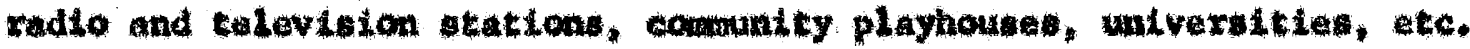
In a service type guoug-ma draetox is frequently the only pald member and wany plays axe produced entinely by volunterts. A good exemple of the comunity service group dolng chlldren's theatre by adtite is the Seatche Junior Rrograms, Ine. sarving wore than mL1Lon people in the

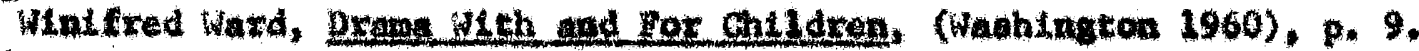
3

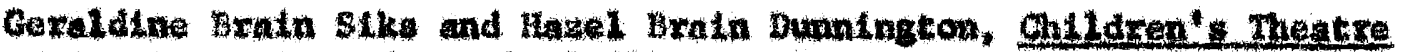
and Creatudo Dremacter, (seattle 1961), p. 33 . 
Seatcle area and eaxning tte budget anmully. This civic group opongora progxan wth the Wniveroity of Washingtom" Sohool of Drama witeh aro 4

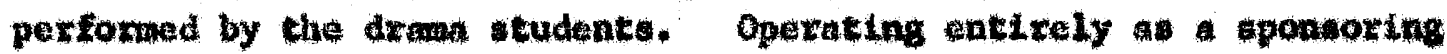
group it has renehed anually over 13,000 chllaren. It hold: a nation-

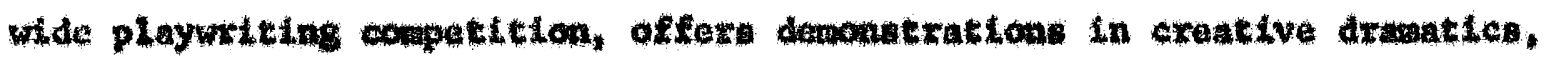

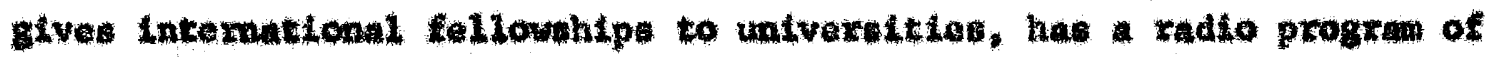

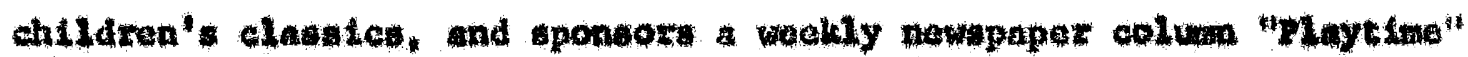

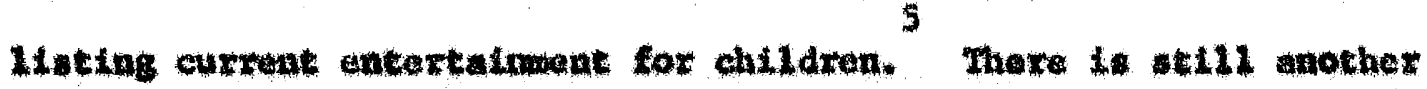
group called the Fantasy Falr Blayere, composed of the graduated of the Univerbity, haxing in the plays offered. Each play 1- presented ton thos in downtown Seatcle theatres and two perfonnances of ach offered In the wuburb:

The second type of adult theatre for children is the edueathonal Institutioan. Kany colleges and univeratctes, public and private, followtng the Lad of Sorthwotem Untvargtty have become producers for

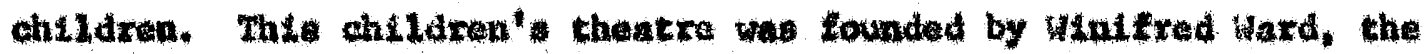

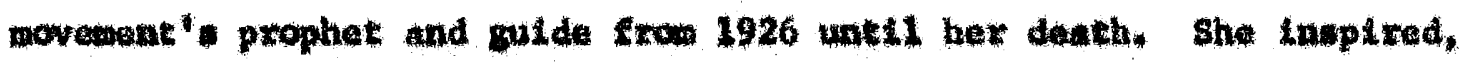
adviged, omguled, and wote children" theatze. In the univeraletes 1t the function of the theatre progxen handled by the proteatore in the theatze departwent. Sehool theatre in oubsidined by the university and the overhead to covered. Whey have only to collect thatr immediate

\section{4}

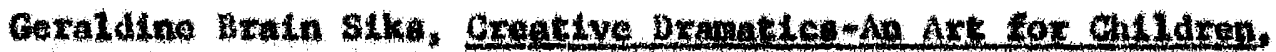

(New York! Geston and hondon 1958), p. 109.

3

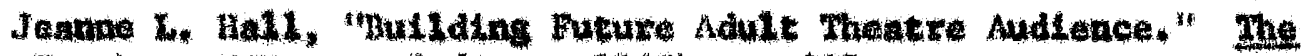
Speech Teachar, KIV, No, 3 (Sept, 1963), p. 237. 


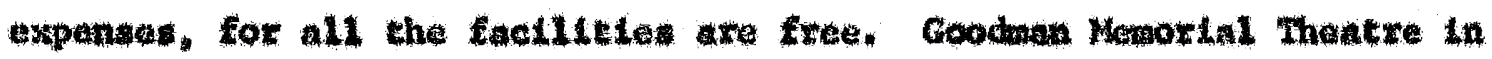
Cileago la also one of the oldest organtiations producting plays for

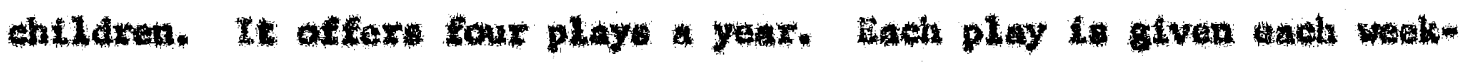

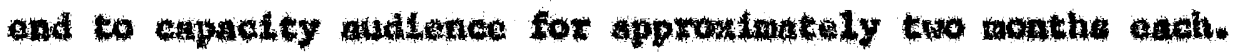

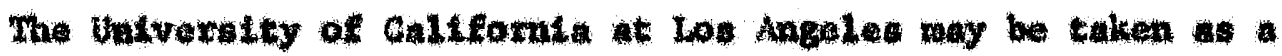
mone recoth exmple, Ith Departmont of thetre Arts gives two plays a yoar wth often third a that project. Ekeh play la pertomad 44 thes to audlenses of excm 500 to 750 . PLym are coured, alko,

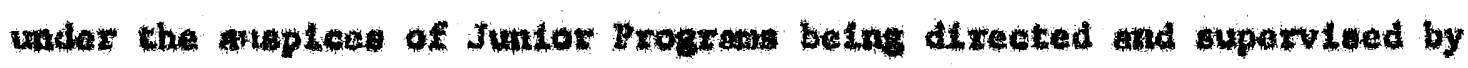
tho full-the taculty mombero.

The last of this group is the professtonal-eownerclal producers. These theatres opening la how theatro depend on that: cour for wain

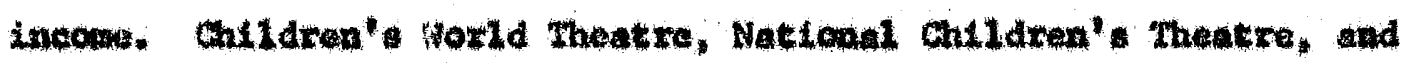

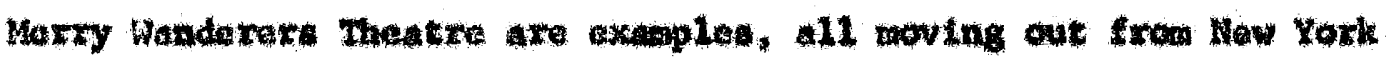
Gity. They depend on lowal aponsors tho often are commected whth protemstond. booking agencles.

The second con of chtldran" theatre lo entldren" produetion:

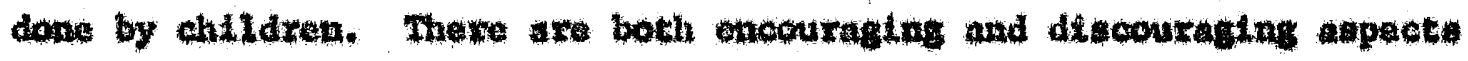
to the prowetng of plays by chliaren. $x$ has problene bacaued of (1) Lak of good sortpte for enlldren to produce, (2) evidance of poow

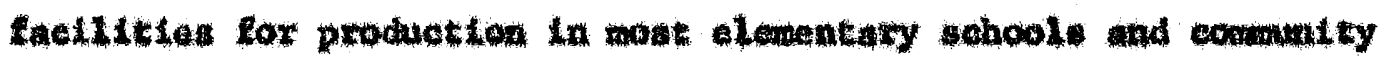

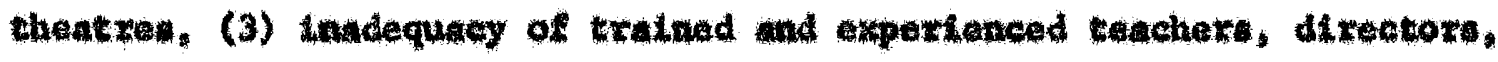
and oblld actors, (4) lack of romeareh and atudy in this area. several

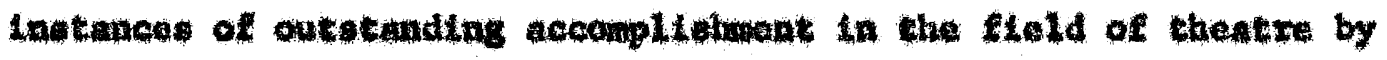
chlldwan ara hopeful stgn of the realishtion of the tmportance of chis

6

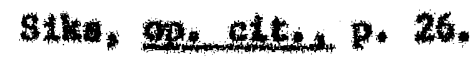


kind of expertance. In Youngetown, Ohio, tho civic Children the The

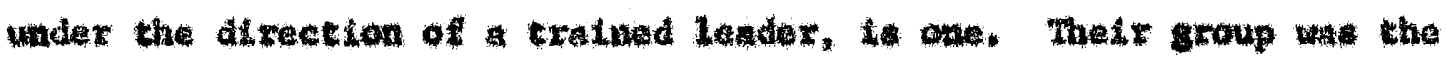

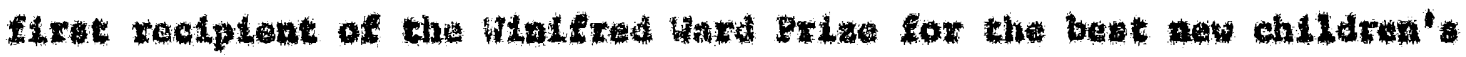

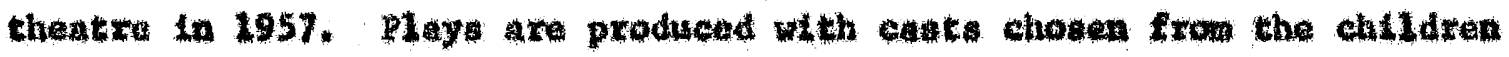

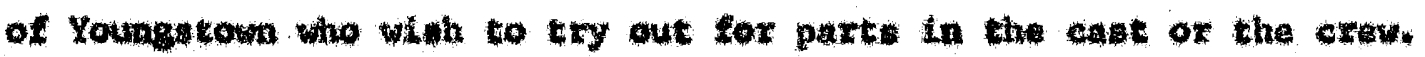
An active participathow in chlidren" thentre in whoh the

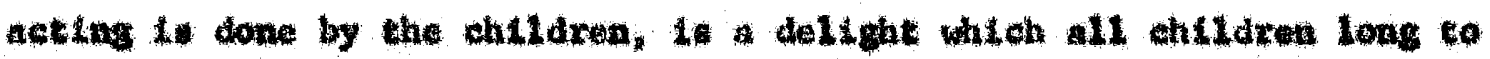

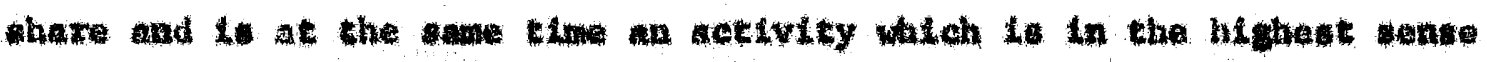

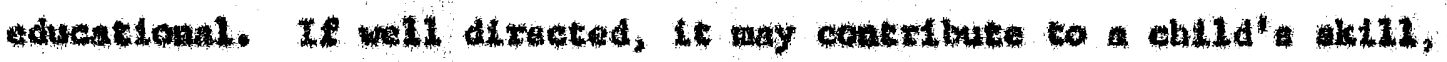
to hio wateratendlas of charactor, and to hts apprectatten of choatre.

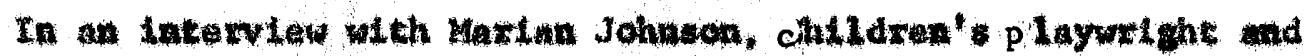
Chldren' Thentro teacher, whophastwed:

Guldwen's thantre whth childron the reat value

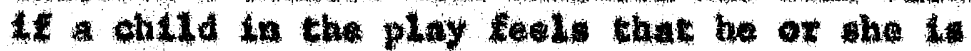

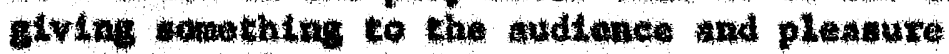
to other chlldxen by his porformanes whther than

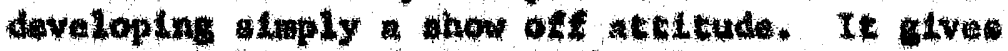
to wany children of tha wddle class, in thin

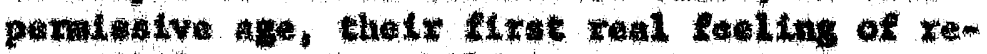
apotidillty. The chlid in the production is Laportant as an Individuni but ratponsible to a

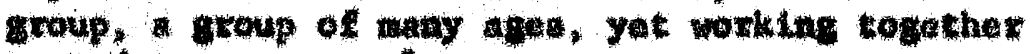
towatd andent.

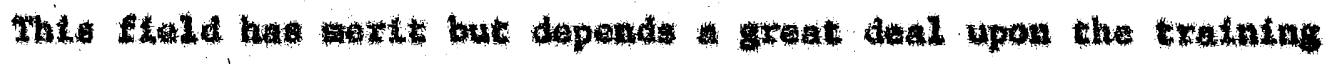
of the drector of leader als dowy fleld of aducathow.

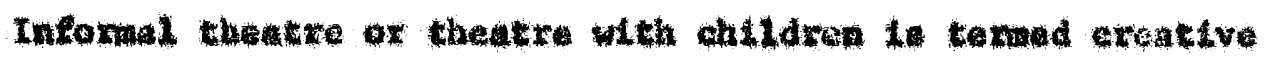

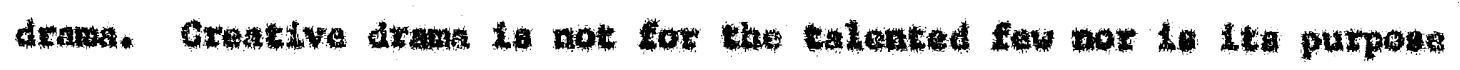
to entertin an watience. Eartelpation 10 all Important and the ext

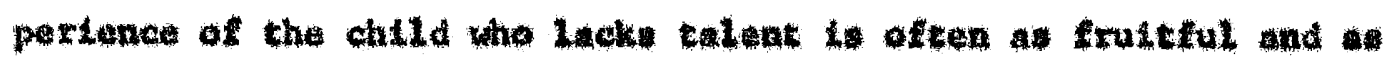
anjoyable that of the thild wh arkad dratele ablity. 


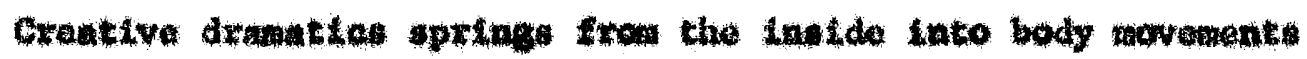

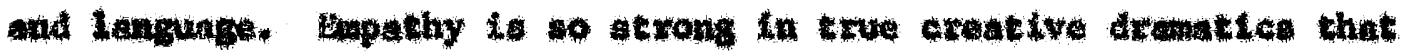

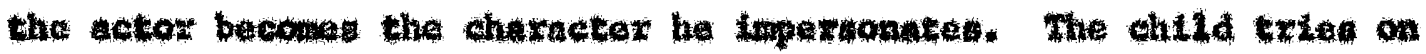

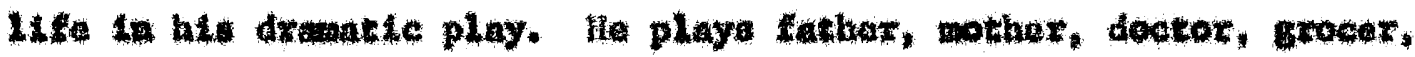

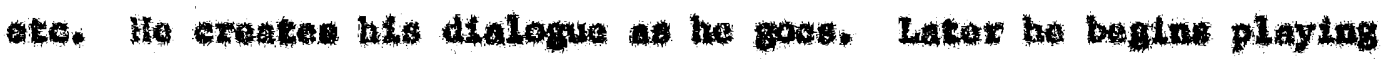

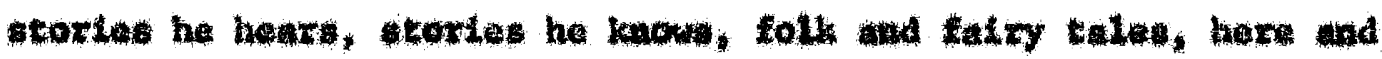

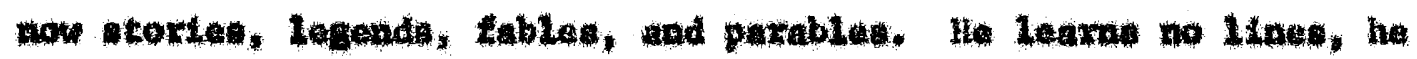

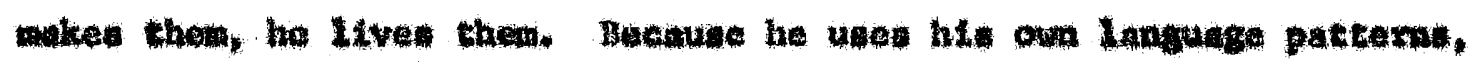

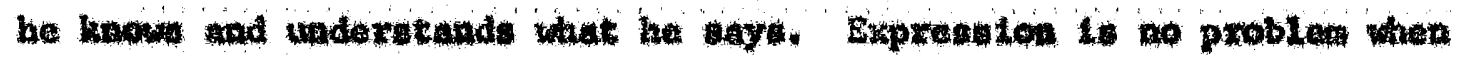

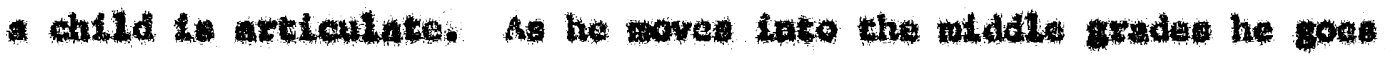

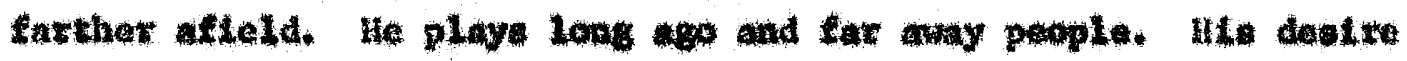

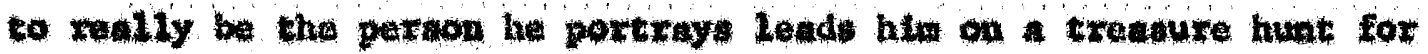
Antomation about the character. He larat how the poreon 1 lved, What he wore, wat be ate, Hat he did, were he traveled, out of this

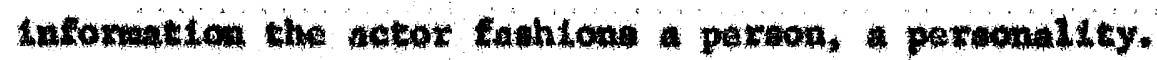

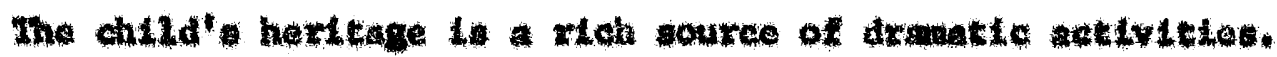

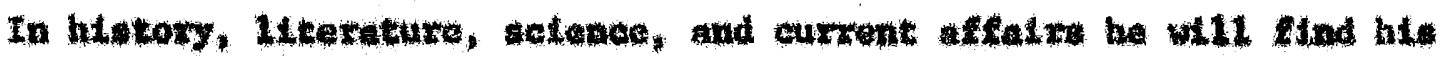
chemes, ha ploty, or threado. He wil gain in vocabulary, toctul

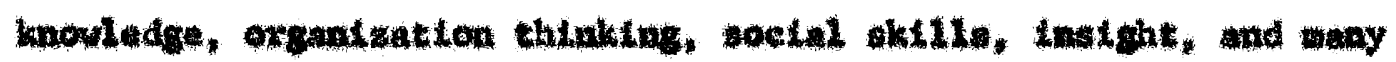
- thex intanglbtea.

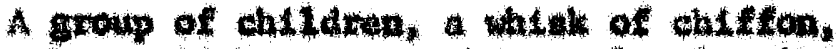

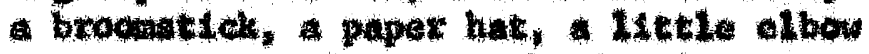

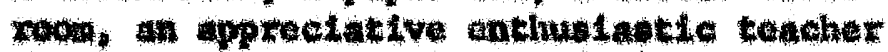 there are the tngzadtente of elcuentury ehool drmatlet.

\section{7} 1959), p. 23. 


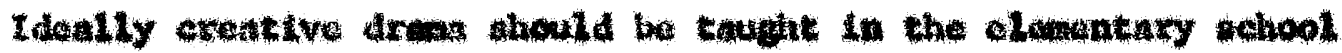

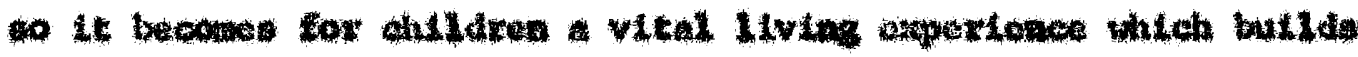

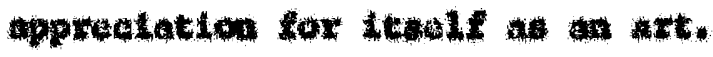

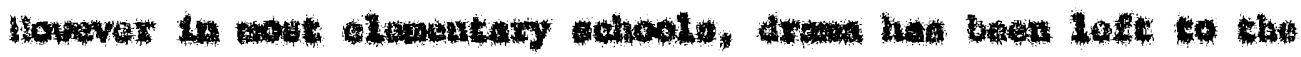

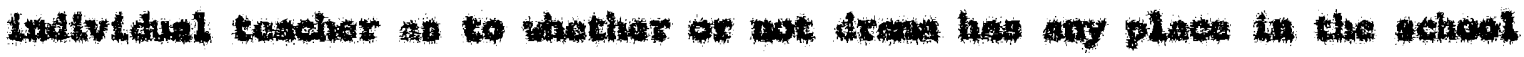

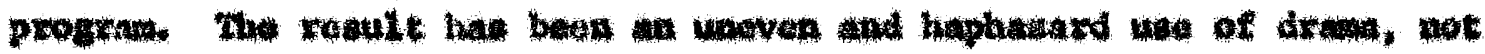

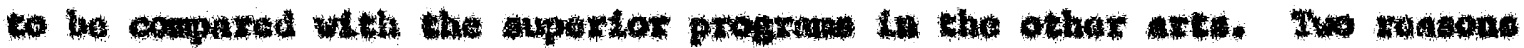

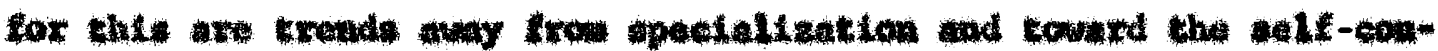

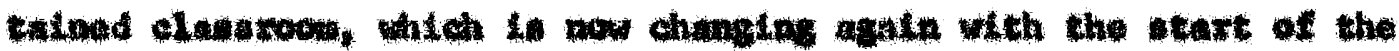

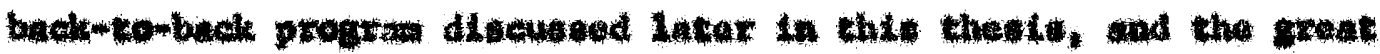

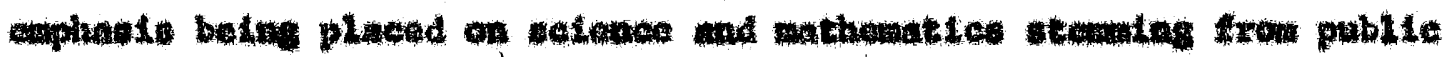
indant.

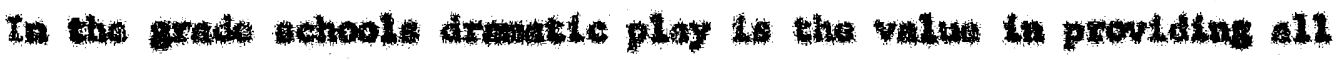

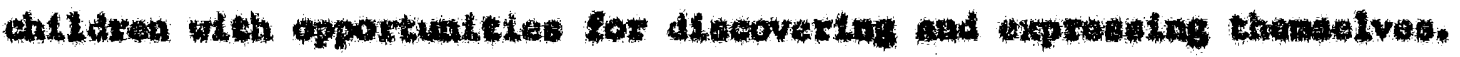

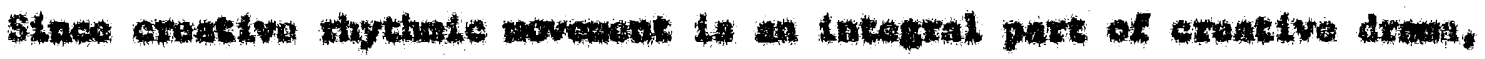

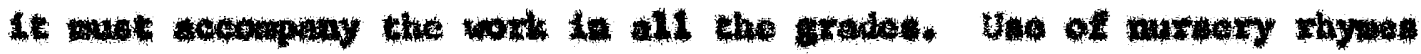

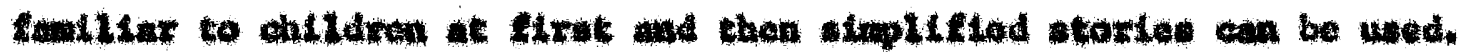

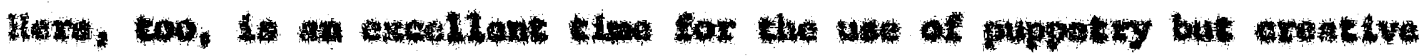

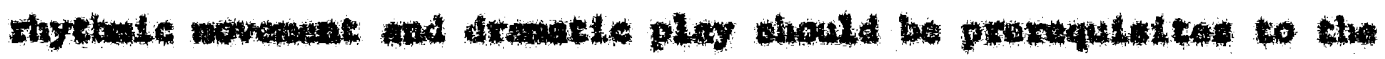

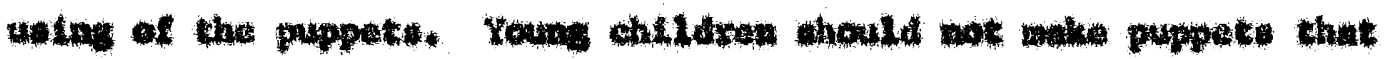

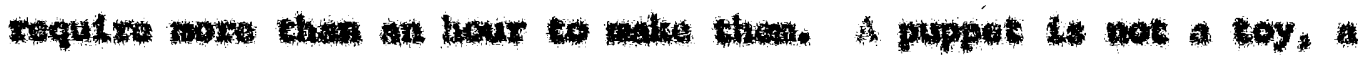

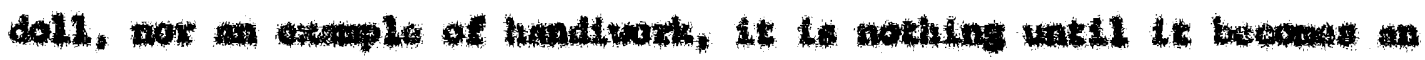
8

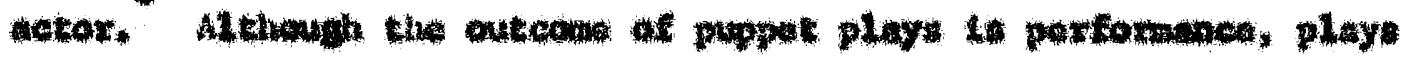

3

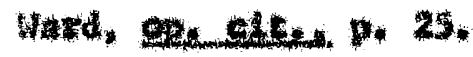




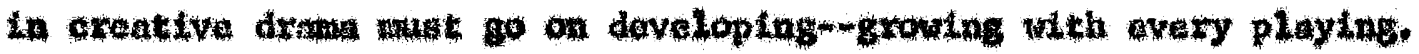
Then tha ehildren have had oxpertenee in (1) dranitle play, (2) creative movenent, (3) situation and charactartatition, thoy are rady and eager

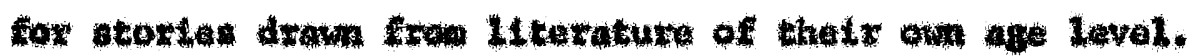

So much of the value of creative drand comen from tte use in a

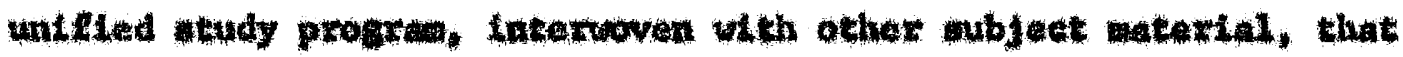

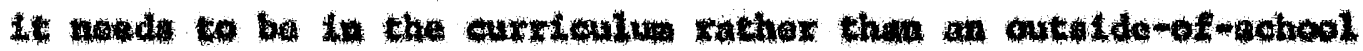
atcivity.

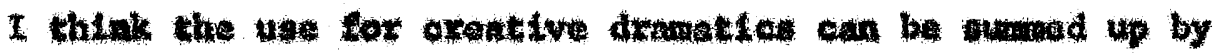
Winctrod Hard in hex statement:

If w to protuce people tho have tungtinationough to do

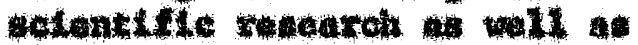
to wonth wh others to matintalin a self roverning state-memphais. on welence and wath wute be balanced by a corresponding on the axte and humentefas.?

9

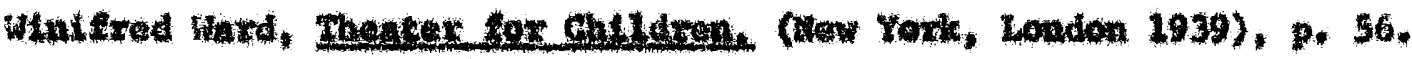


CHAPTER II

BACKGROUND OF CHILDREN'S THEATRE

Before delving into Rortland's use of drama to educate its lementary chool ehildren, one needs to know, not only what drama 18 for chlldrea, but how such drama developed in the United staties.

Throughout the history of drama children have seen productions upen the stage. The Grecks brought their ehtidren when they came to the great festivals of DLenycus and surely children saw the miracle and moxaltty plays of the middle ages. A fev ehildren were in the plts te see Shakespeare performed on the stage and sav the Commedia dell'Arte performed throughout the countryside of Italy. It was not unt11 tan de Gentis in 1770 introduced a children' theatre that anyone saw theatre for chlldren. The first childrea's theatre was a private theatre on the grounds of a country estate of the Due de Chartres near Paris. There the talented Nme. de Gentis made rich use of drama to tuter hex young pupt1s, the Duke h daughters in 1770. She was the first to realize that through the medium of drama children could be taught-taught not only the fundamentals of history and drama, but also taught dreams of fantasy to stir the Imagination. Her theatre of education Llourtshed until the French Revolution. The plays she wrote for them 


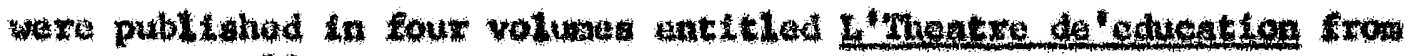
10

1779 - 1780. Twoy woro translated into dizerelgn langunges and

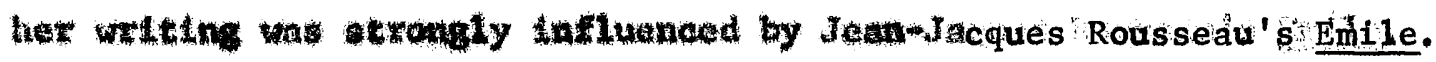

In 1865, 10 tho Dnited States, the production of Joskph Jeftereon

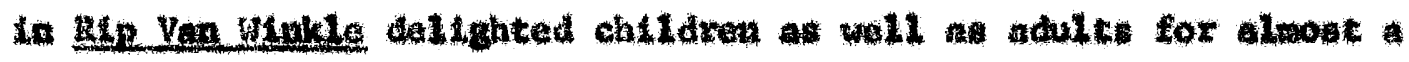
hall ontury:

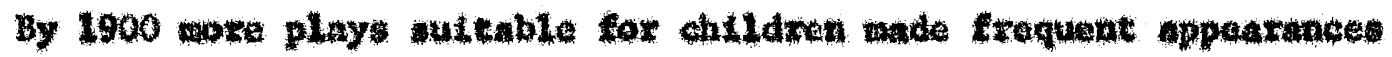

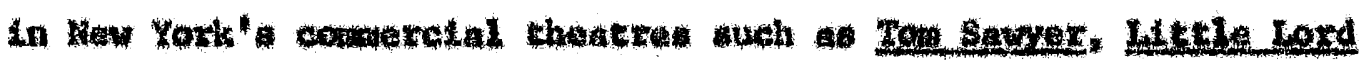

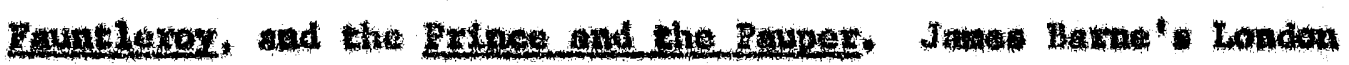

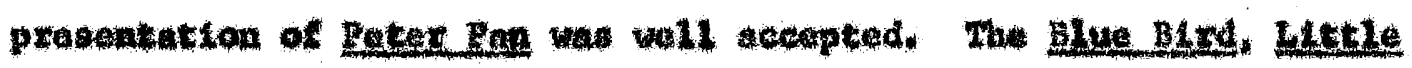

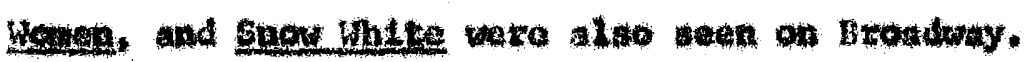

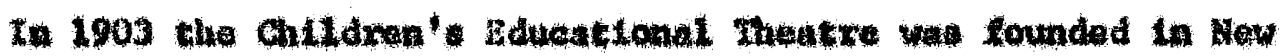

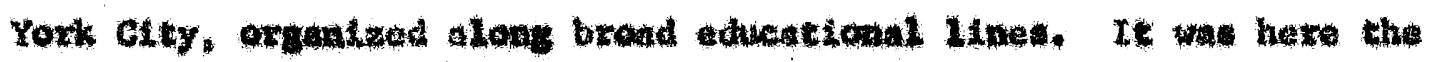

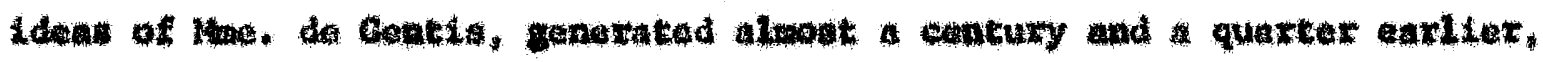

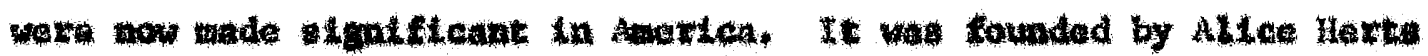

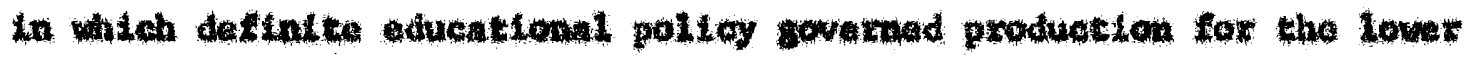

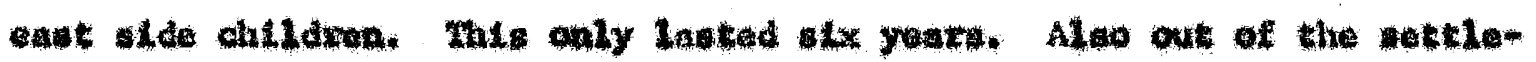

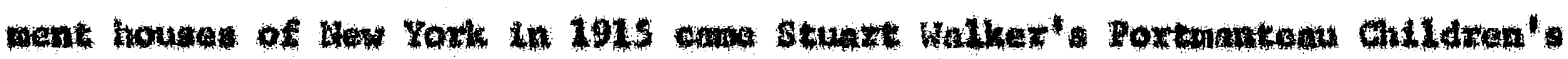

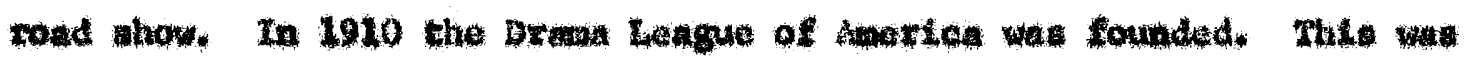

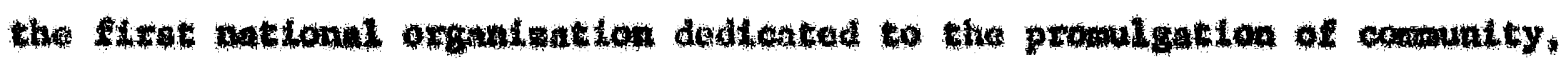

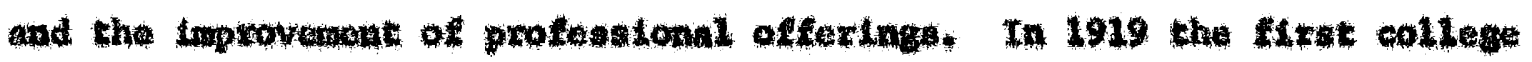

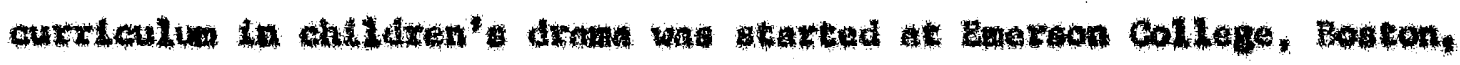
By 2920 profesalonal companies had practidally stven up children's

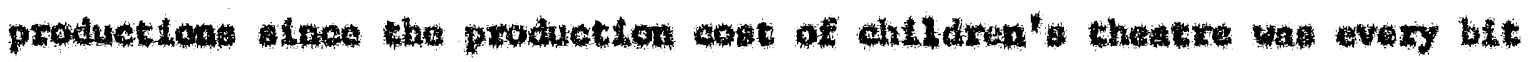

10 Ward, aste, 4 . 
as expenstve as adult theatre. The producers could only count on a house on week onds wecauge of the chlldren la sehoul and could only charge halt-price for seats for the chlld audience. Making a proflt on

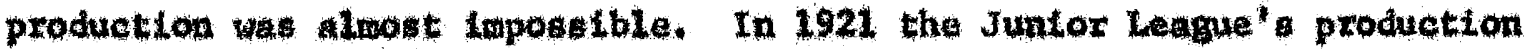
of Alleg in Honderlond in thicago, establiahed program of dramatic activitles rebulting in the Junior League "play Bureau," 11 "y 1938, 148 Langue in the Undted Stutes were detng ehildren's productions. In the sand you as the begtning of the Juntor Leaguels Lnterest, clare Tree Najor began a tourfing company out of New York Chty which lasted three years. The bus impetus eme in 1925 when winffred Ward started the Northweotern Chlldren' themere in conjunction wh Northwestern Undveratty. It was a comunity and eollege project, both working together. In 1926 Undversity of Tulas tarted chlidren's theatre with child actora. In the late twotias the Kng-Cokt Sehool for gating began in New York Ctcy. It was an acting shool for chlldxen age three to twalve which emphastzed acting, dosignlng, make up, ocenary, and costuming for the chlldren. Productione were done an outcome of the achoollag. They were training profestional actors. by 1930, becanse of the depreaslon, the Pederal Theatre was established, As a part of the prograw,

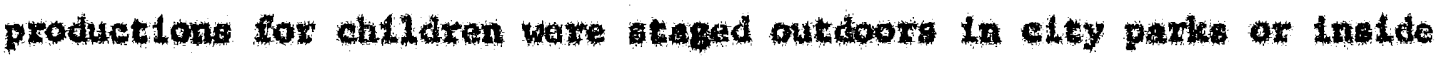
ordinary halls and school auditoriubs, scattared chroughout the fortyaght atates. In 1935 the theatre we establlshed by act of congress and the sack atowed it in 1939. Another great step torwazd for

11 Wara, opcite., p. 35. 


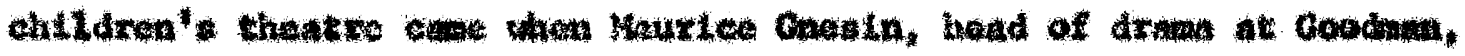
brought Charlothe Goxpenning and Loulda Dale spoor togathor and for

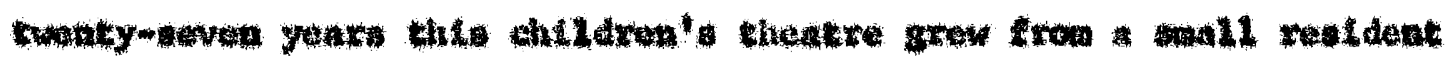

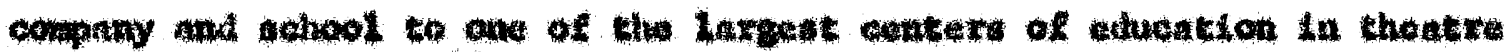
12

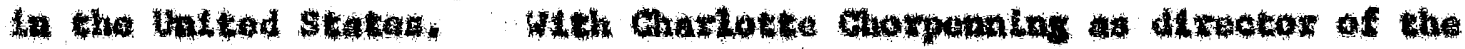

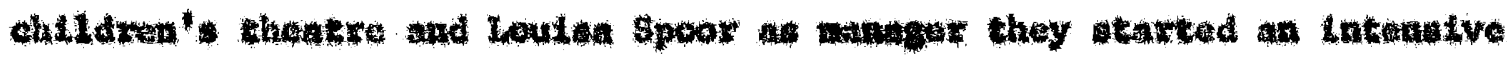

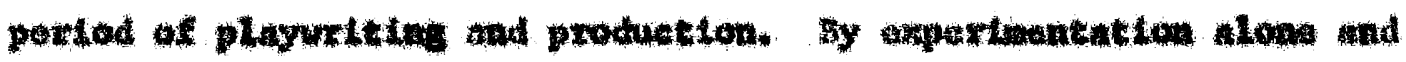

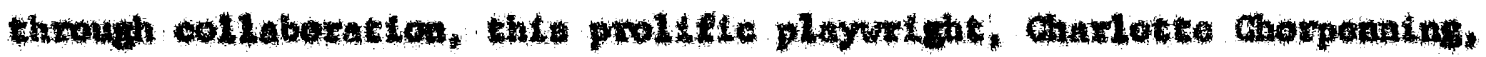
more then doubled the repartodre of good scripks tor ahildran" cheatro.

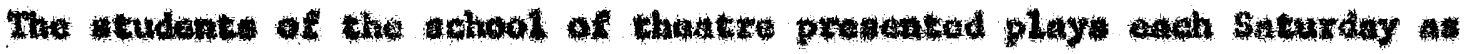

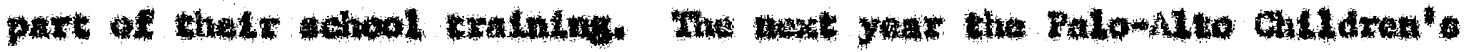

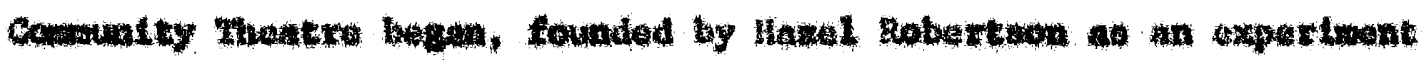

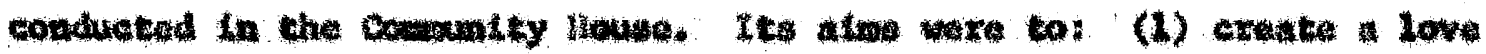

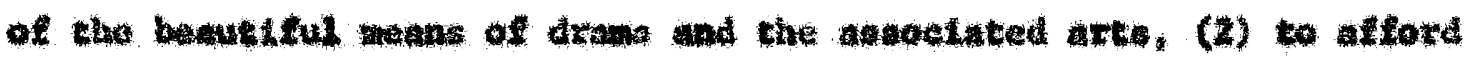

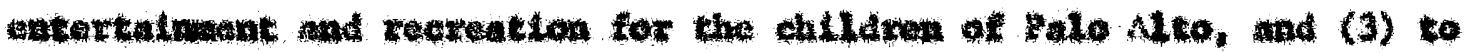

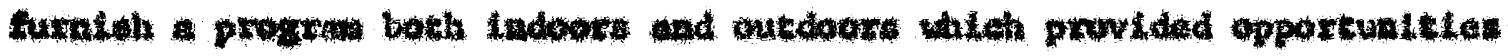

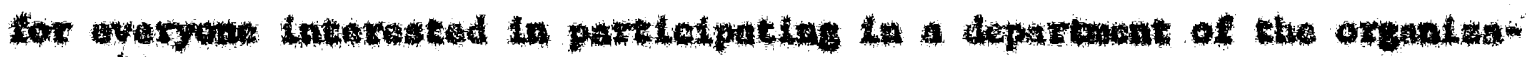
13

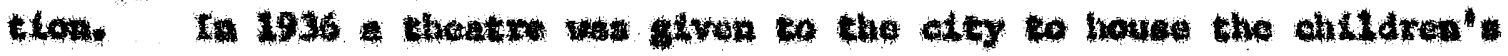

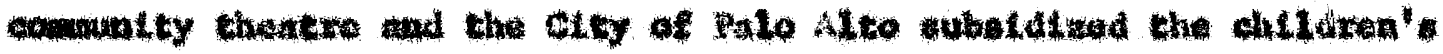

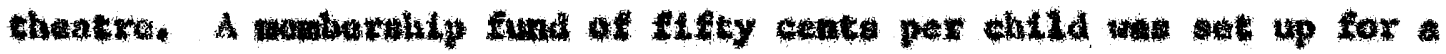

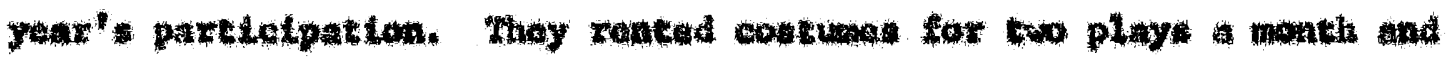

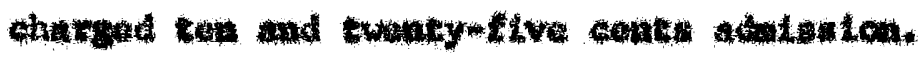

12

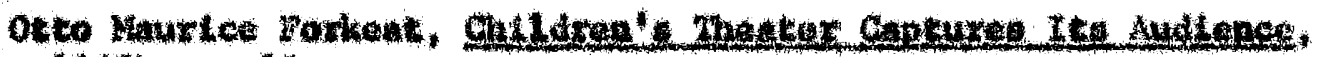

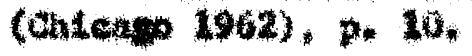

13

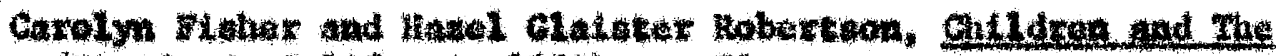

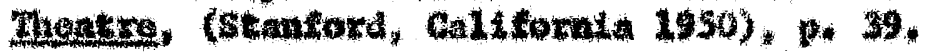


The year 1933 saw the Junlor Programs the. developed by Dorothy Mcpadden, within a very tew years it included three companies offerting ballet, opera, and drama for chlldxen. Through sehoola and conmunity organization its prograns were toured to hundreds of elties and towns. It conducted the most extensiva campaign to bring entertaiment of quality to boys and gixlo. In 1935 crace Prtee Productlons atarted, which was a regional profesalonel touring corpany, at a moderate cost. Acoording to 1t: cecorde, during seven years of its exiscence 1,300 perfomances were given by this company, 700 performances were given by othex companies which 1 t booked and over 40,000 children made up a total audlence in 43 stater. 14

In the area of publication was the founding of the ChLldzen's Theatre Press by Sara Spence in 1935. It is a publishing howb devoted exclusively to the printing of chlldxen' playg and related materials.

Whth the organization of AETA in 1936, the organization debignated In 1937 chlldren's theatre as a spectal woxk project. By 1944, the ChLidren' Theatre comittee was founded, later to become crc, concened exclualvely with children's theatre activities including those of educational, commolty, and profisglonal ortgin. The flret weting was held at Northwestern under Minifred Nard's direction. In 1950 publication of its own nowsletter under way to keep members of cre informed of entldren's theatre activities throughout the country. It was published by the Children's Theatre Press, Coach House Press and Samulel Pronch. ${ }^{15}$ In addition

14 15 Davis, og cett. p. 114 Geraldine Brain Biks and Hazel Bratin Dunnington, Children's Theatre and Grantye Dranaties, (Seattle 1961), p. 17. 


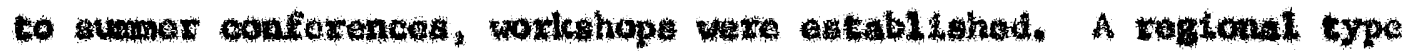

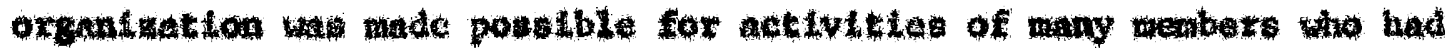

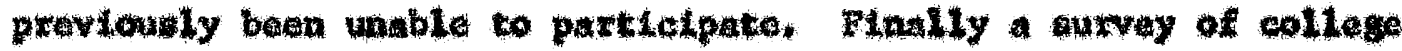
eurrtcula comploted in 1953 produded evidence that both playk for

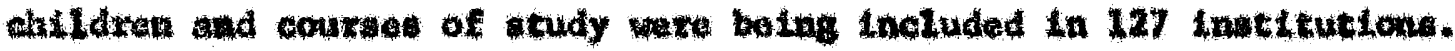

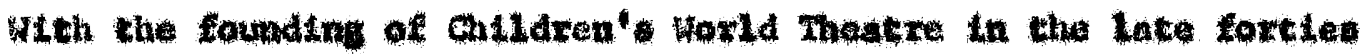
anothex profeantonal company boran actulty, but the donth in 1955 of

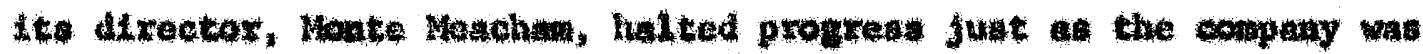
beouthe nationally known.

The Conegonng wac included in this thats to give the reader pletume of and of the force throughout the yeare and acrove that

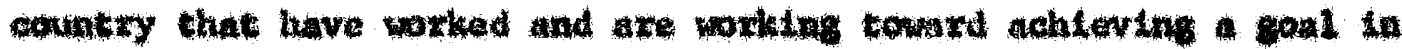

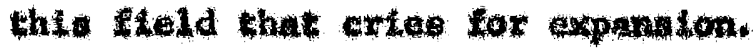




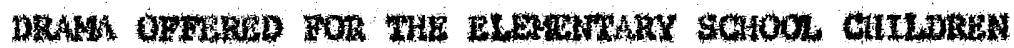
IN THe rowakToNAL FIELD

\section{Porthand Public sttoolo}

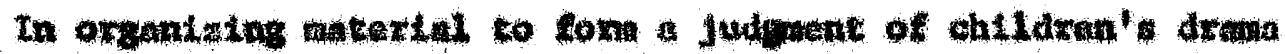

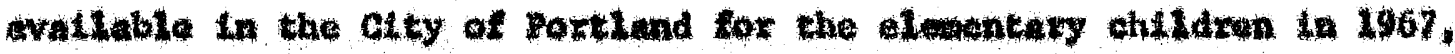

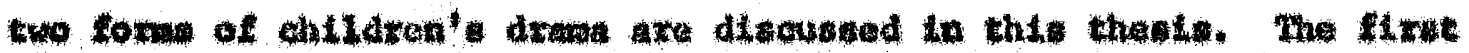

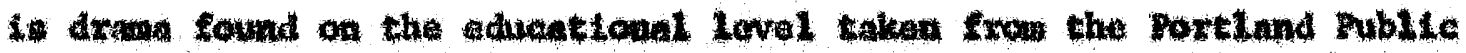

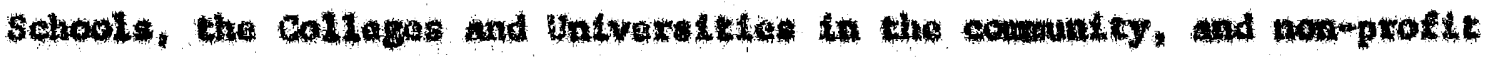

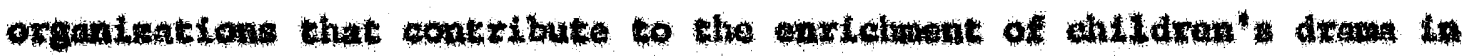

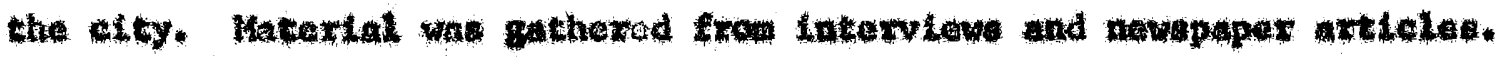

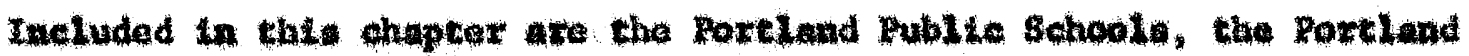

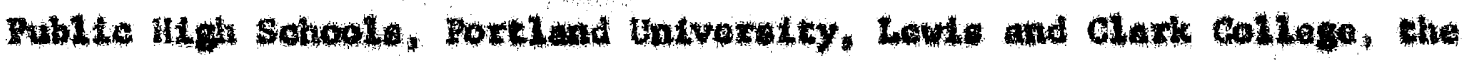

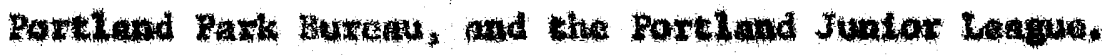

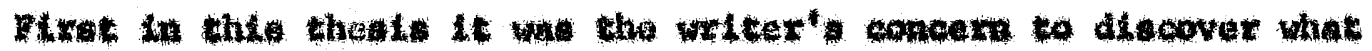

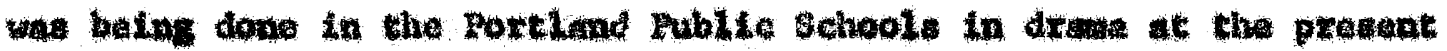

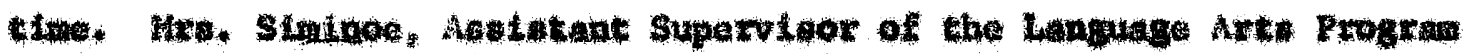

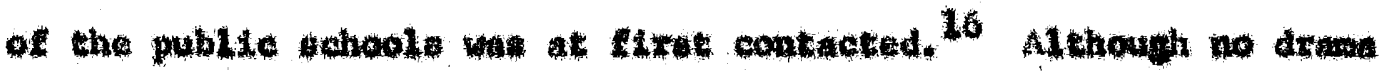

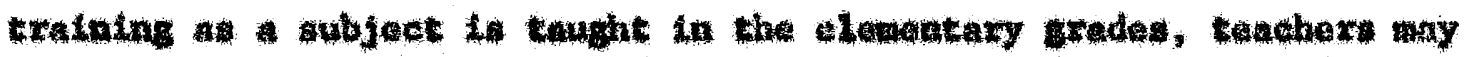

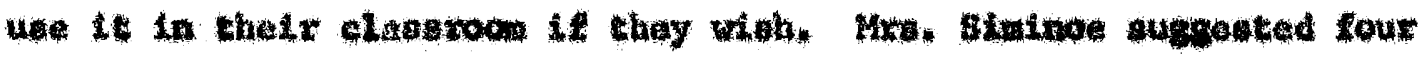

\section{6}

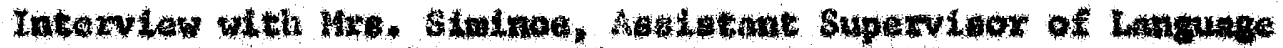

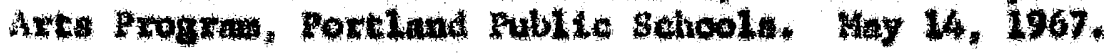


teatuer. co contact in the schoolv that huve been worting with then.

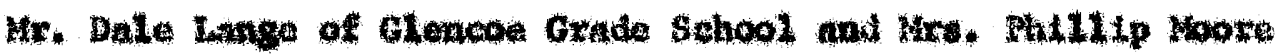

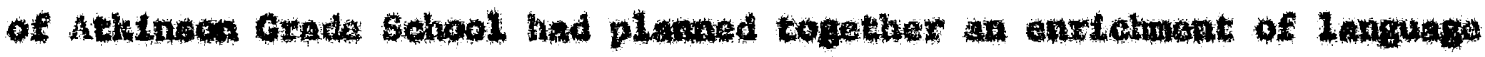

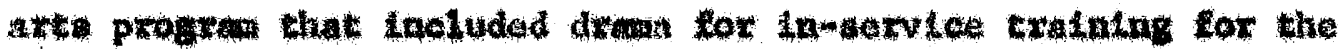

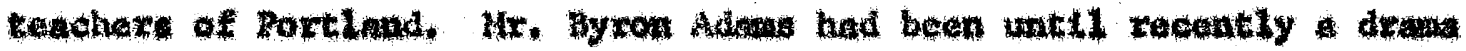

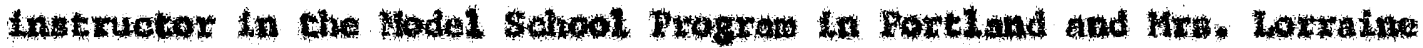

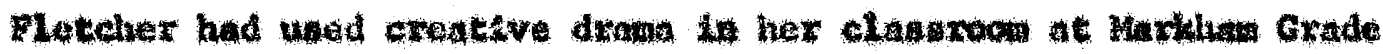
Sehool.

On concactug Mr. Lange at clenoo Orade sehool he explatned that

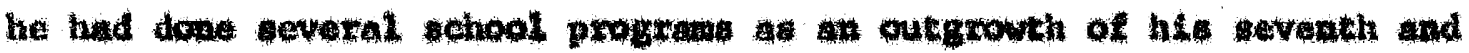

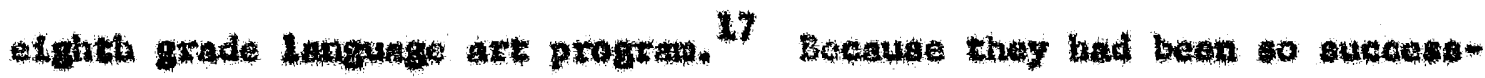

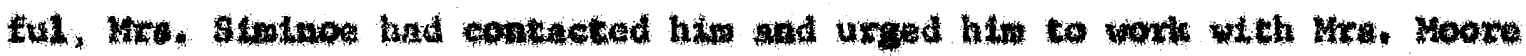

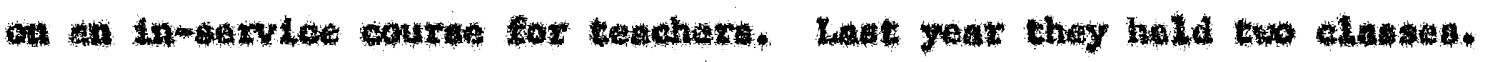

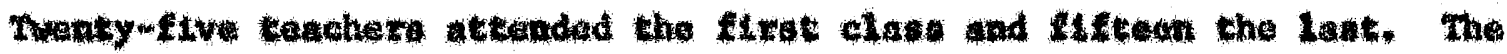

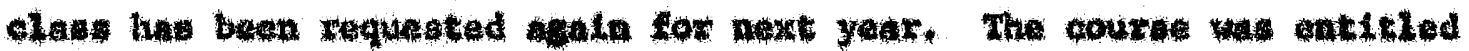

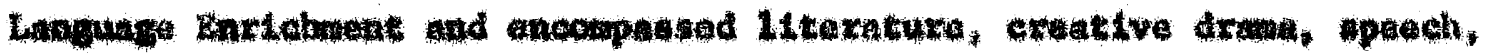

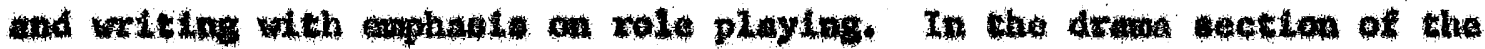

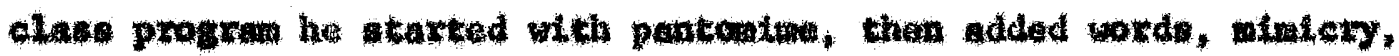

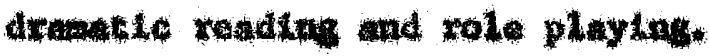

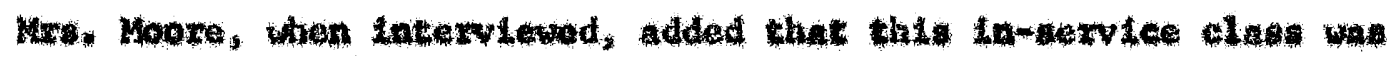

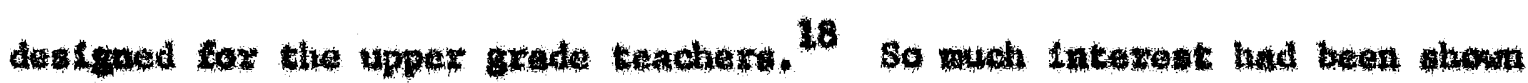

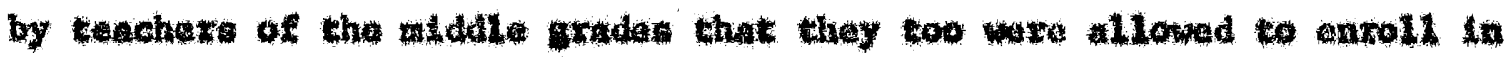

\section{7} 18

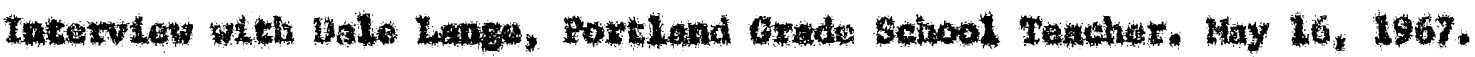

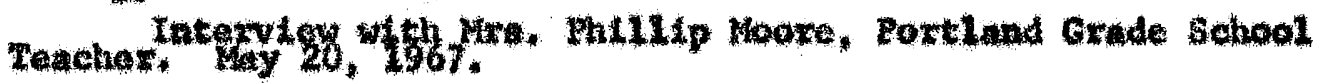




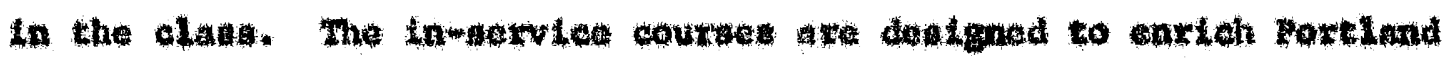

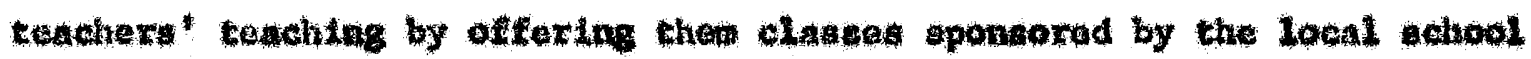

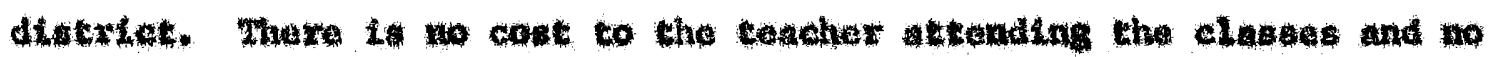
colleg credtc given on the completton of the conrse. Atikineon Grade Sehool, where Mr. Woore teachos, is on folative now plat to thlo

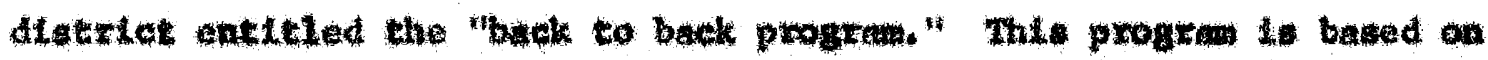

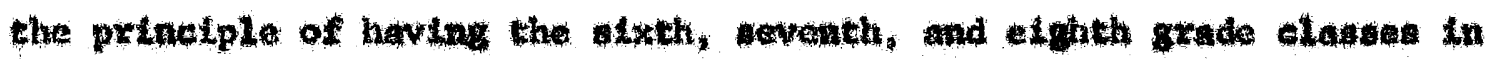

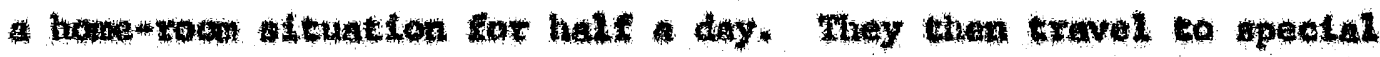
clusses the rest of the day. In the schools having this program, the

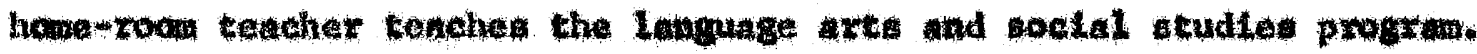

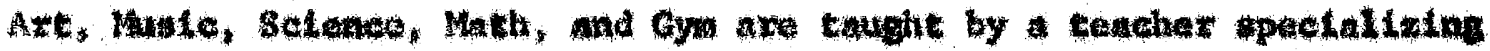

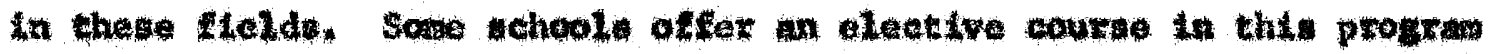

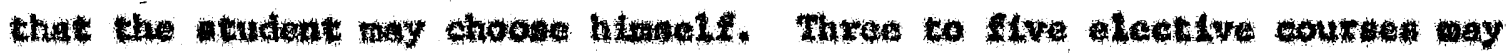
we offured to the atudent and he $1 \mathrm{~s}$ ontitled to attend the elase once or

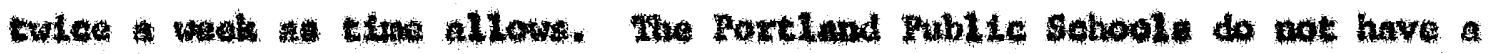

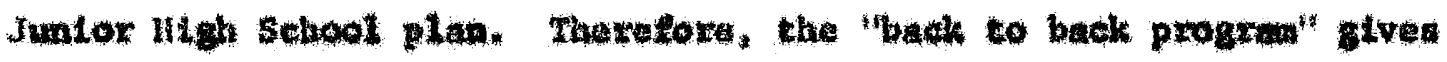

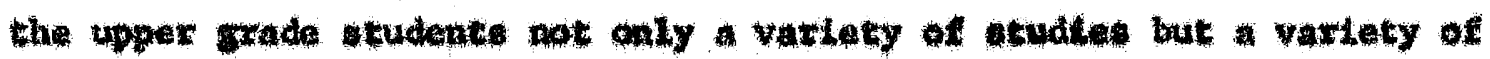

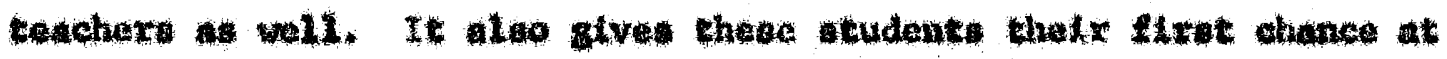
anking hoteds.

Mrs. Hoore hod an opportuntty at Acktnon Grada Sehool to

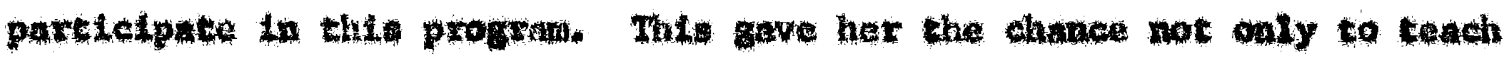

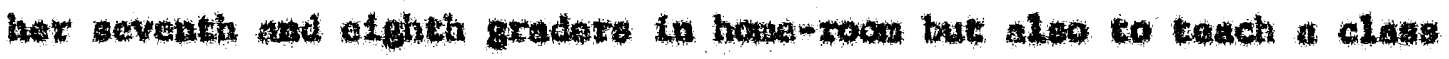
offered only to igheh Bradors of speech and droma. This class was

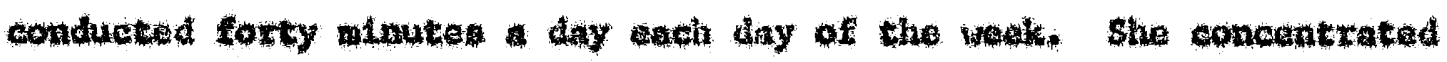

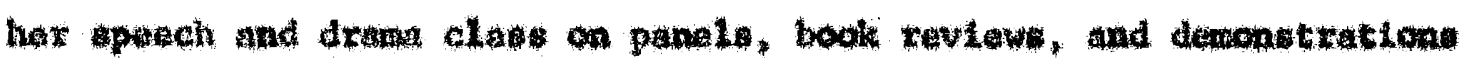

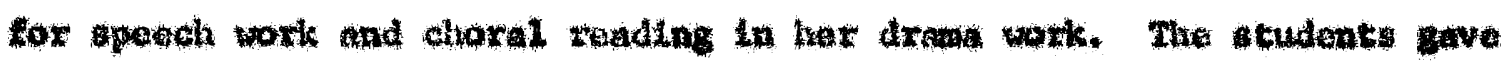


ahoral rading progran for the parants at hrutrad. Her otudents

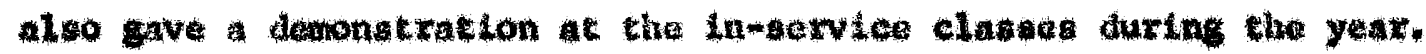

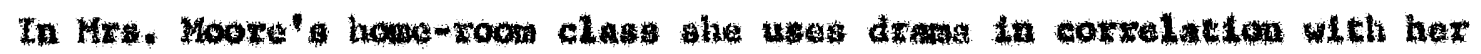
1iterature progran and has found groat deal of material to wo in hex ruglish caxt booken.

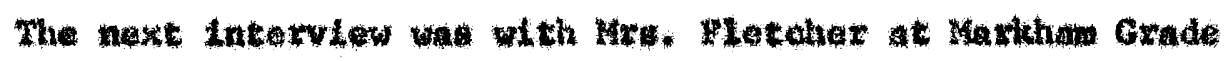
Sehool. 19 a cordial Invitation was otfored to vite her claws of atxth

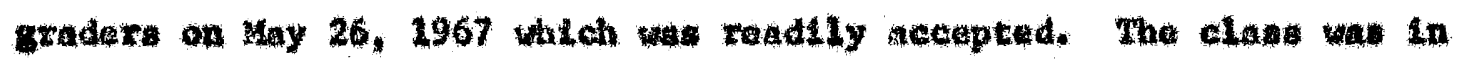
the proctes of giving a presontatton of an adaptation of AL baband the Goxty ahtaves frow chat wixth grade reader in the auditortum. They had tmited another stath and fleth grade elas th the sehool to

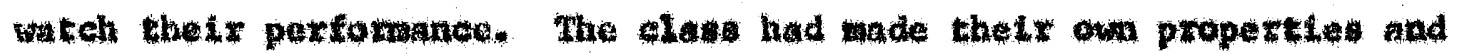

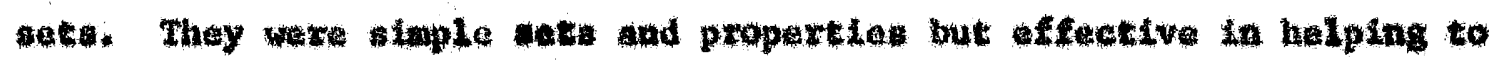
tall the story of their play, One staple atample wat the horees tor the thieves to ride, The horwe had been tamioned of a broowatick wh paptex-mache heada. The atudatto wore gular ohool dother but ereated

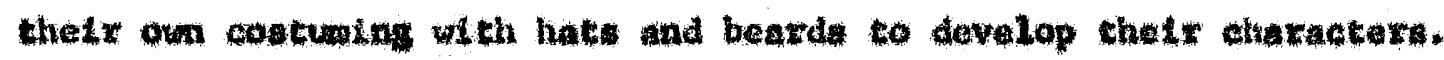

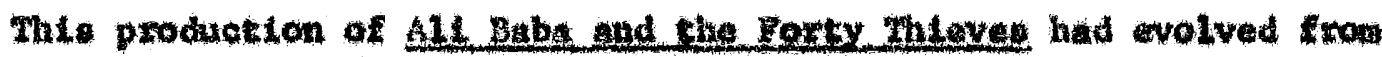
a reading srowp. The children had chosen a boxy they thought they eould dramatte the best. They had reheartad it by loproviting the cenes. Thoy were puttins on play written and compond by themselves: Ofter scenes wexe not wrtcten at all but wide "on their on teet" whon

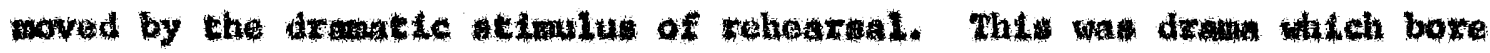

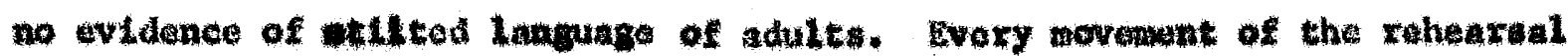

\section{9}

Interview wh Mrs. Lorratne Flotohax. Rortland Grade Sehool Twacher. May $26,1967$. 


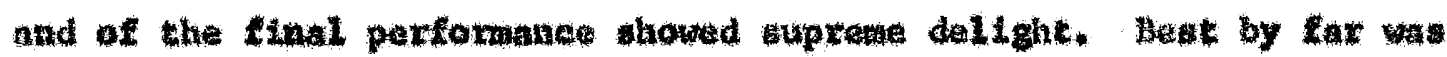
tha renction of the awdience. The children th the adience enjoyed the play because tho actort put all their chlldish axhuberance and excitem ane Into pertoning the cale. Mth twenty-alx childxen on the atage the play ran very anoothly. There wa no fooltahnese on stage. The we re very oumest young actor trying to tall their atory. Actor the play over the bov calcen, and anchusigtic audience laft the

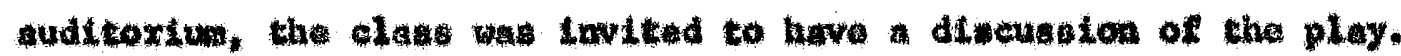
Nro. Fletches posed the queston, "What the children migt heve done bettex?" Thig wat with eager partclpation by all the cagt. They were

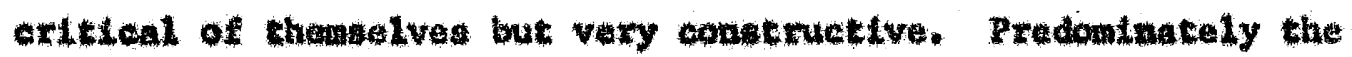

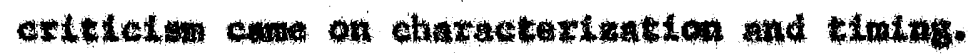

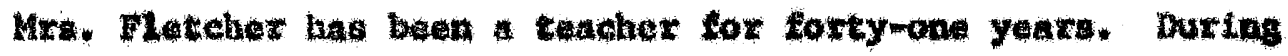

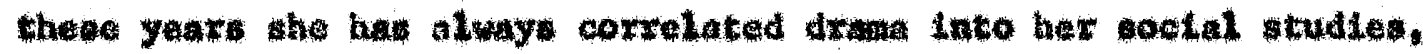
readiag, and language art progran no mattex whare the chught or what

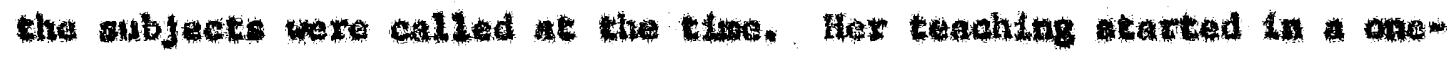

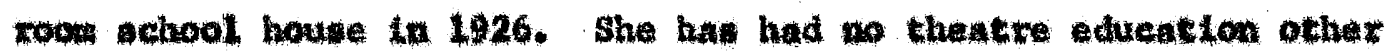

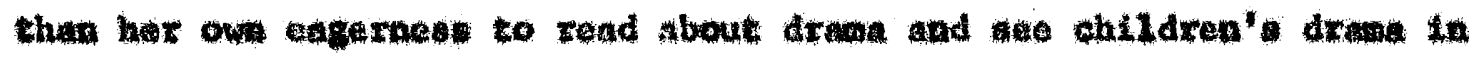

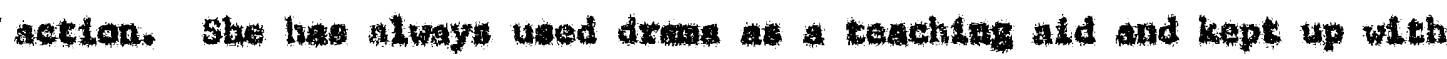
Its teaching Leas and techaiques by studying on het own.

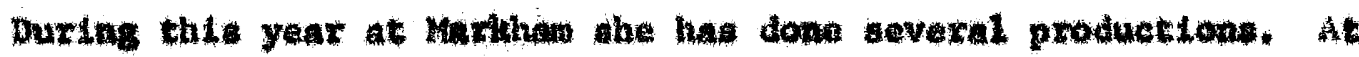
the firac of the wehool your kar alass put on exentive play for their

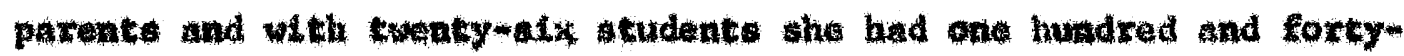

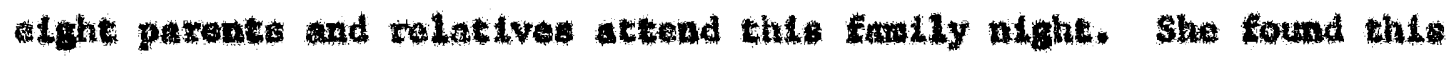

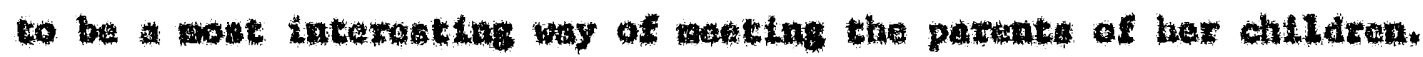

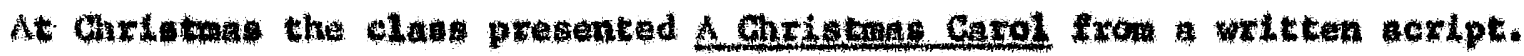
This put an for the wole chool; a project Mra Metcher has done 
for the lat faw years. Thie wo double cast wo that ach ehild hat a chanca co wotk in the real play. The coscumes and bet moro elaborate, th the nelp of parents, than was genally done ta the

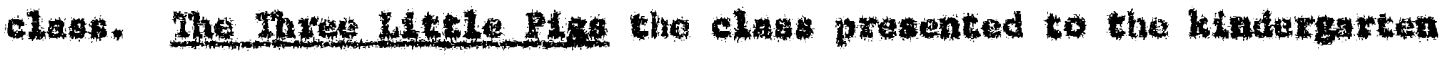

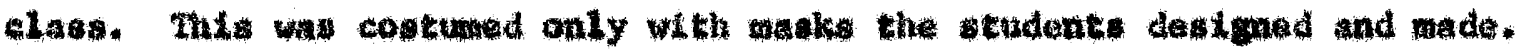

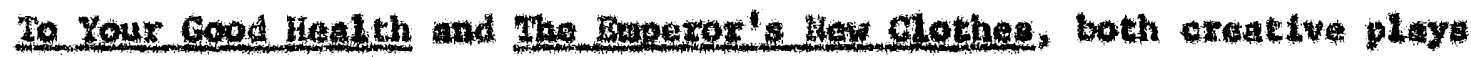
from thefe roding progran, wera giva in the atditorium for the primary

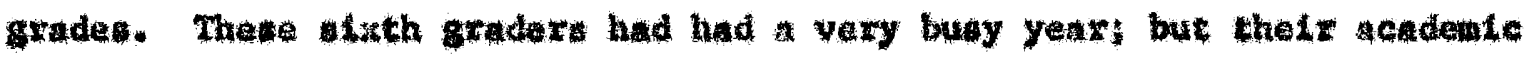
work had not attered.

On retumang to the clasgroom, after the play, the drudents showed

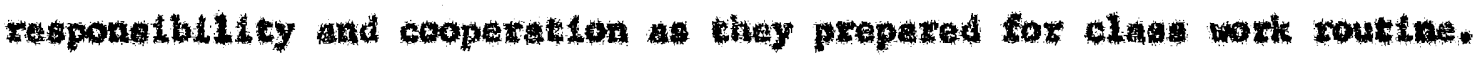

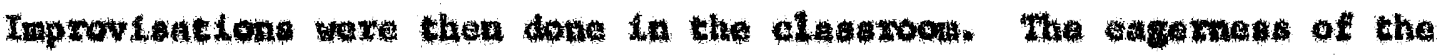

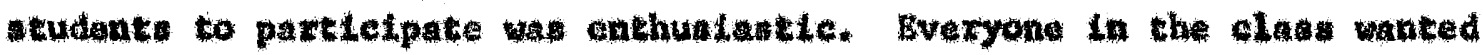
to take part in thase role playiog tmprovlontono.

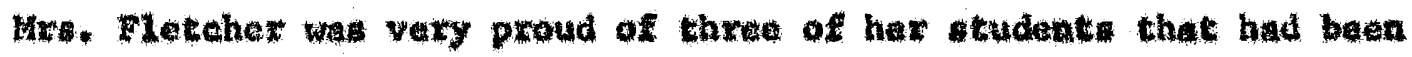
elected atudane body officers for the fortheoning yoaw and acerodited it

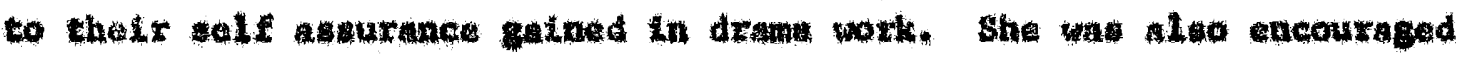
by the contaglous foeling that had been aroumed in the wehool. Fve

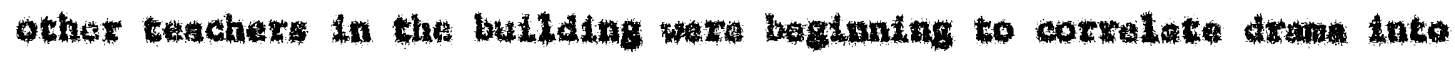
their teaching programa. Mlthough whe ditucouraged that more was not

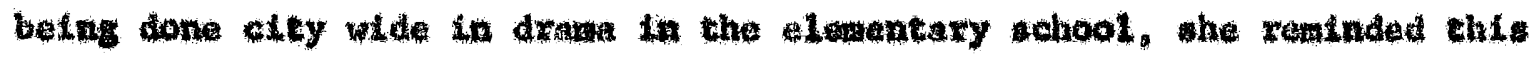
whter that least ha wable to toach drama 14 he chowe. This was

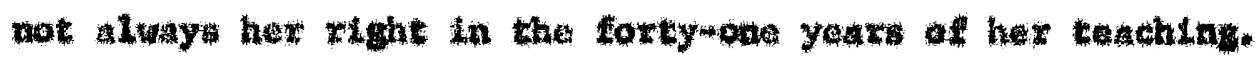


Mr. Byron Adan, fifth grade teacher ation Park, had unth this year wokked in dram for the model school program in Portland. 20 The model school program was atabllohed for the underpriviledged chlldrun of the Poxtland area, providing special craining and education to this low income group. At the progran"s conception, Mr. Adams was involved in currteuluo plan of epech and drana for these children Which ho presonted to the adminlstration dapartwent of the ochools. He

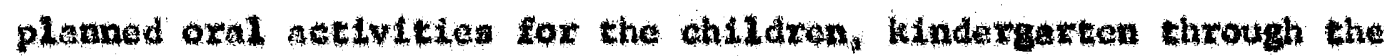

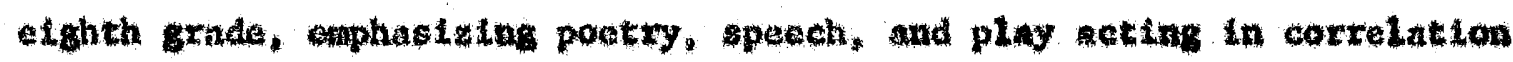
wh the rading and pocial atudits progration. Nine schools were involved In tho nodel achool program. For two years he went into the home-roos

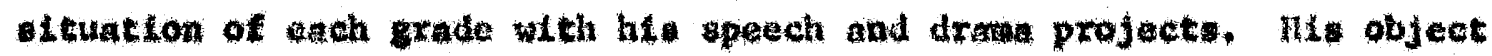

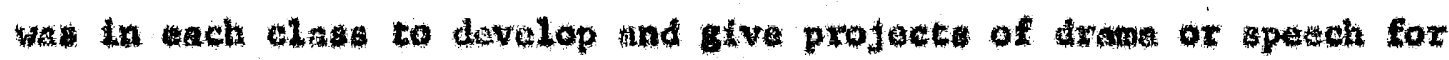

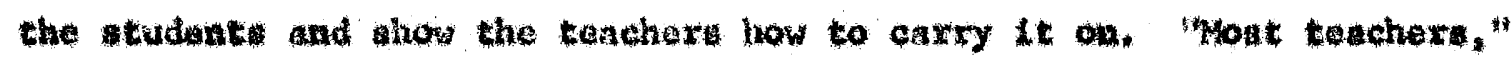
he wald, "took this tho for thel cotfeo break and did not seen interested the projects." He whe left to carry the progran himelf:

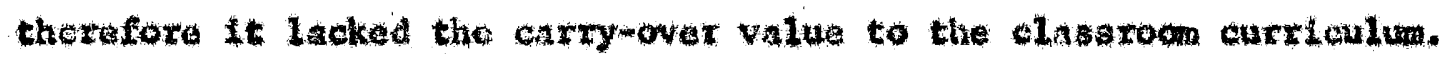
The prinary gradeg he found very receptive to the progran, but aftar the fifth grade he had troublo introductng the progran to the studants. Wh onlt minly with specth and choral reading work and did nothing

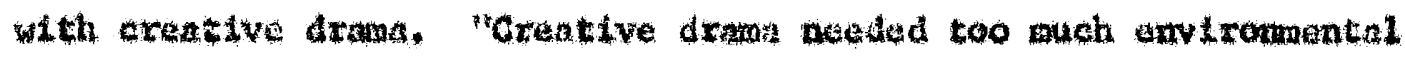

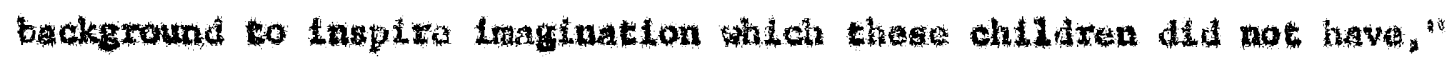

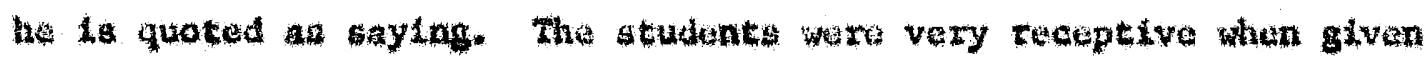

\section{0}

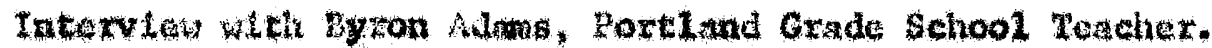
(ay 20. 1967. 


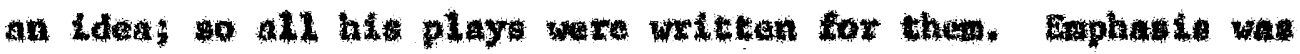
epeciflcally on epeech woxk becauge thls fit whe ho found the children

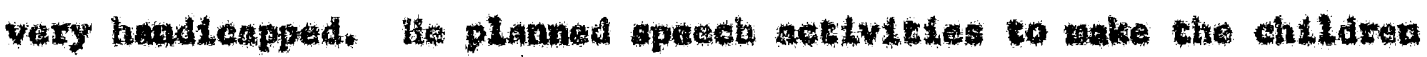

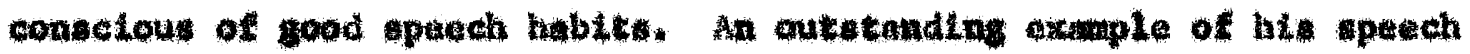

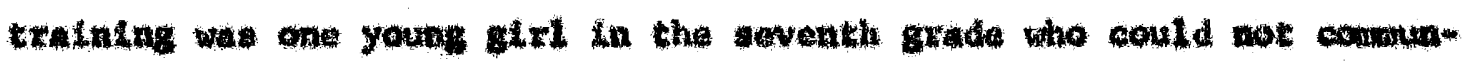

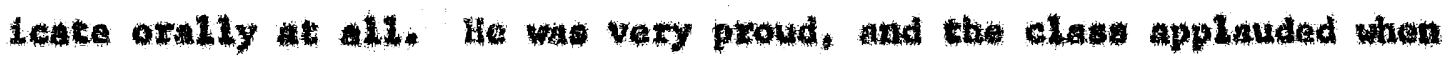
Ghe spoke complete sutente for the las at the and of the tem. For rold playlag he found it much onfex to rely on seripte bacuse

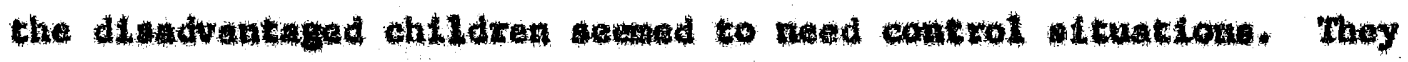
necded to know what was expected of then at all thas. If not in a

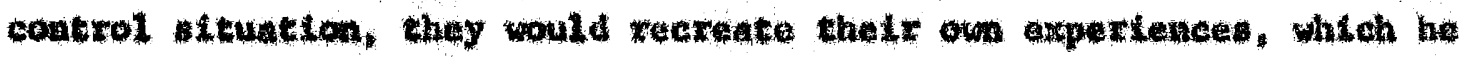
felt wara very notative.

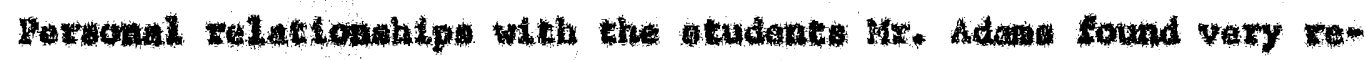

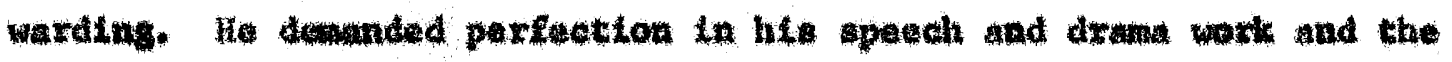

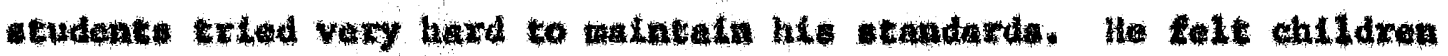

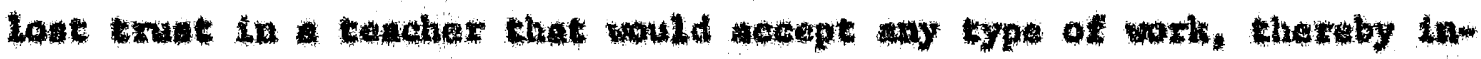
sulting the child.

Mr. Adewe has had areat ded of expertence in drama to was. before working in the wodel school pronrwa, the drums coach at Girl'.

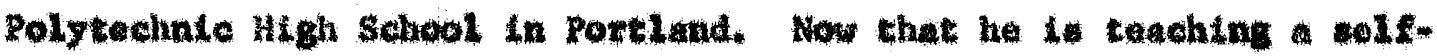

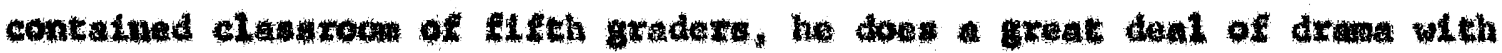
the chlldren. Hits celing is that drana in the grade holds a grant deal of tenx for the average temehex becmus we fent the las of control of her studants in oudh arentwe work. 
The Portland Public sehool through-out the clky have for severgl yours offered sumer school classes for chlidren, Mindargartan through

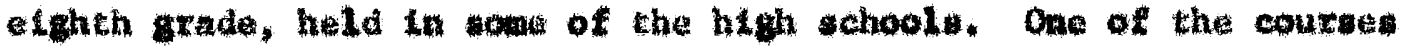

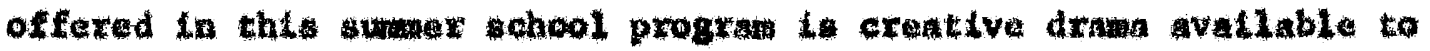
fourth through Ighth grade onfldran. On Juae 28, 1967 it was the writer' opportunity to visit Grant High school, one of the high gehool.

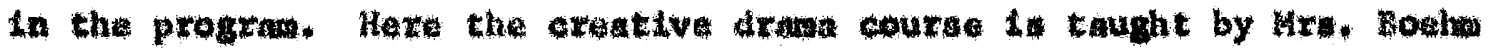

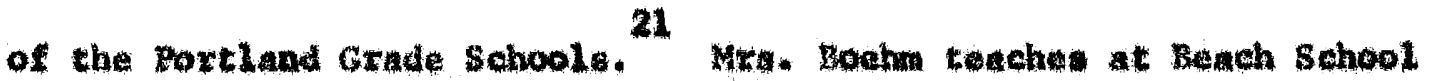
turing the cheol year, a meventh and exphth grade howe-room* Alno at Beaci on the "back to back program" she tonehes two claseas of creative drand on an elective buslis. These clasues open to soventh and etghth grader wet two thas a wek for Lfty minute mon periok.

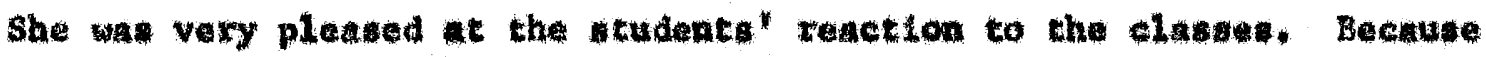

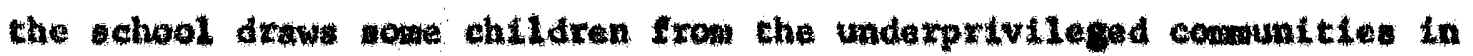
the city, whe found wo of hex children blosmoning in this claes where they had not in tho acadente aubjects. The claswas were beld in the auditoritu at Beseh crade sehool, giving the children the opportunity to work on atage.

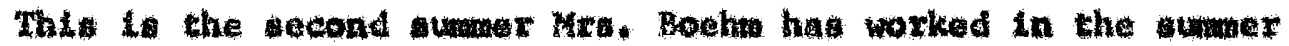
school program in ereative drama at Grant Hgh Sohool. She ia graduate of Oregon State College ln Lemuntary educhtion. Bven though the has never had acaderice tratuing in drawa, hex outhustam and teaching techniques for hax classes comes from Intendve study th the fleld of

21 Interview wh the Bohn, Porthand Grade School Teacher, June 28, 1967. 
children" thentre and creative drana. lopetully in the future the can find trac in hor busy shodule to take wome graduate theatre training.

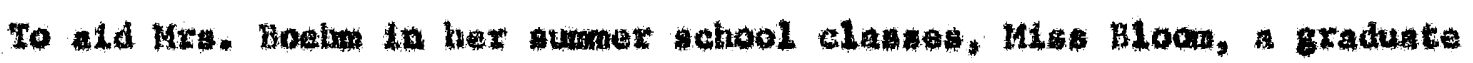
this year of Winon wigh School and enxolled noxt year at stephens.

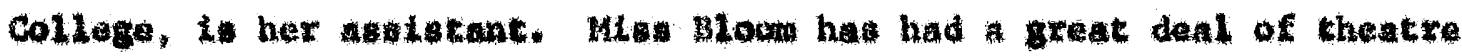
traintug in high ohool whe the won two druma avarde at her graduation.

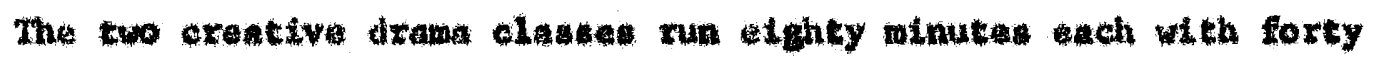

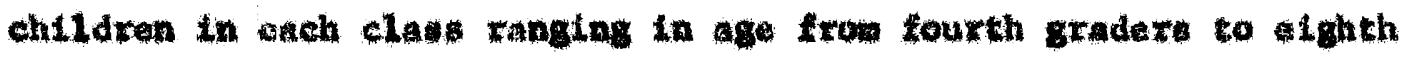
gradere. The clasen are held in the Grant thigh sehool theatre dopartment, which conuldte of two roons. One rocm is ued for uet and property construction and tho other for class work send rehearsals. A ereative production is glven at the and of the four-week pertad at an open houge tow tha parantu.

Mre. Boah atarts her clages with improvisations with erphes: on concentratton, moou, character, devaloping into dialogul. Interwoven Inte the firat weth lo cory telling by both the teacher and the antecant, with the iden of encouraging the children to choove atoxy they would Iike to devalop for that opan houne presuntation. This

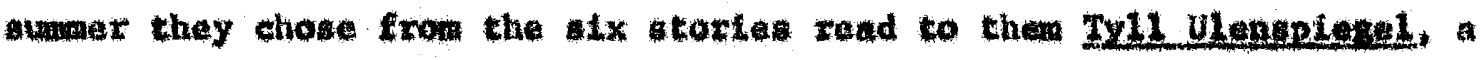
Corman tolk tald. The class then wartad lmpxovialng their own scenew fxom the story. By the second week of alnswe the chlldren audition

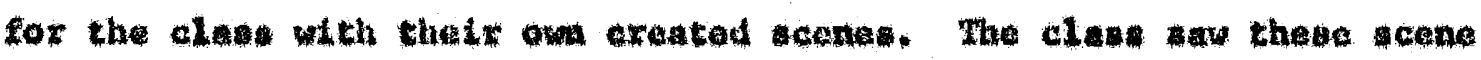
presentatione and chose the cant for the play by voting. On the writer"s viattation day the class was in the proces of discusaing the organiantion of thete play. The cast had already been selected. Ten 
chlldren were working with KL: BLom In tha adolning room on the net design, which they had alrondy presented to the olaes. Thoy had dectdod wht propartles were needed in each scene and how the otage whe to be dreased to wach set.

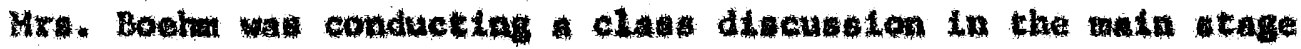
roow. The atudente wexe deciding on the introduction, attack, cowplicatton, major extsin, and resolucton of the play they were planning. Huxt they dfecuesed the stage set proposal, oent to they by the

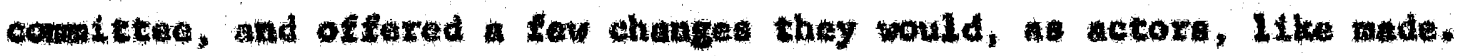
In thil discumaton, Mra. Boolw brought in the thestre tams applied to the use of the stage (up stage centex, down atage right, as axtuplea).

The tmprovising of the firot weene wa then prosented by the cat on the thage. Thore is no prosechiva atage is the room. A curtoln dividas tho roo into gtage area and audence space. Therefore, matny

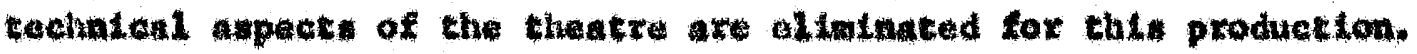
After the thrt scene wa prowented, the cant wa Imvtted to stand be-

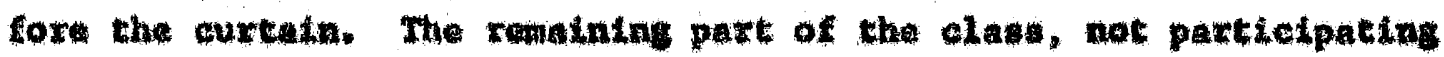

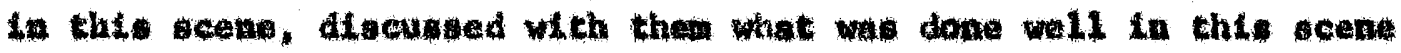
and wht nooded improvement. The alase enterad tnto the diveusaton

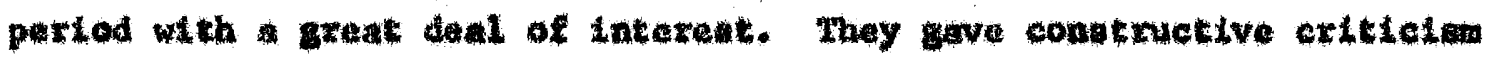
of the problew factos the cat mats in that characterimations and stage movenent:. The scent then ropeated, The children tried to Improve their presentetion, heeping in mind the oritiolom that hed been mate. 
The cluss pextod ome to an end whin the discuswion of costuwing the play. Lach student was raponatble for hip own costume. Slnce the pley wat at the afdale Ages, tunice mode out of plllow case were auggented by the teacher. The sudents' own ereation aloo encouraged.

Hro. Bow kept the children vLtally interested throughout the

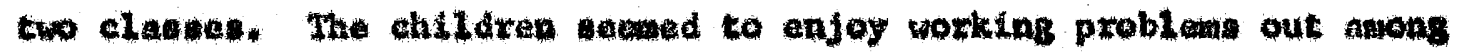

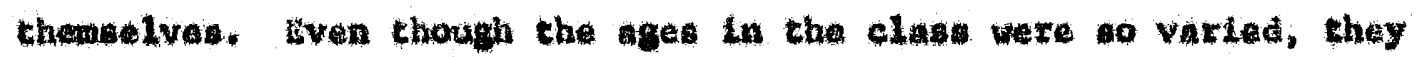
cooparated axtranely doll in focushng theit attontion on the objective of making grod production. 
rowtand Whin Schoolu

A concluelon of a furvay that was sent to thirty directore of

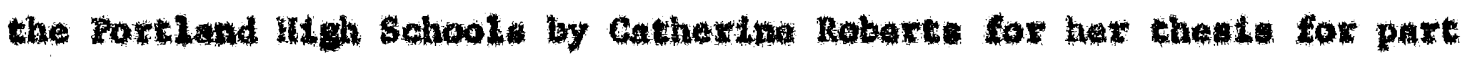
complation of her moter degree in 1961 at Rorthand Universtity tended to point up the tact that little lo balng dane in the bigh

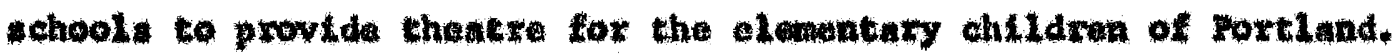

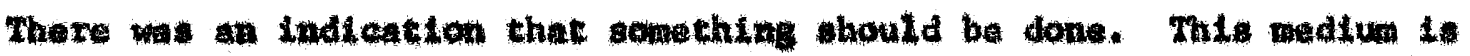
not betng used atthar as acting technique for the uppex achool

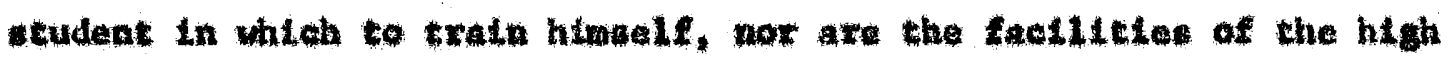
-chools being utillad to provide Inopdration for the lomentary tudant

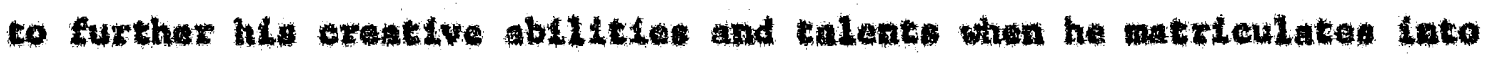
the uppor tield of educution.

of the quedtonnatres sent by Mre. Boburte to the thirty Portland Public High sehoolo regrarding thetr echievenent in theatra designed for

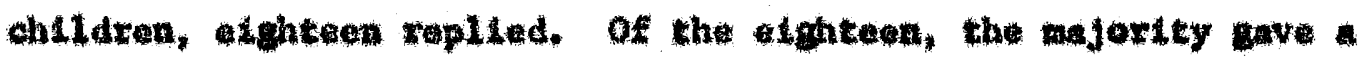

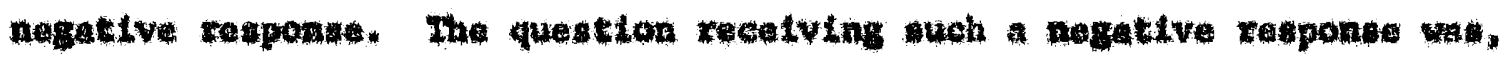
that has buen done in the lnst five yaare in your achool in the fiald

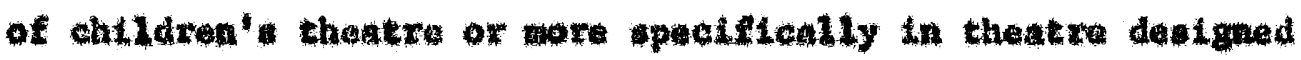

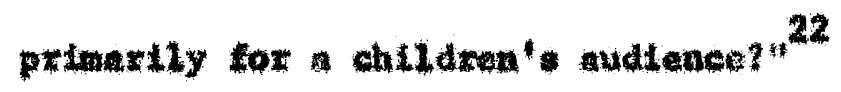

\section{2}

Catherine Fahoy Roberti, "A Concept for chlidran's Theatre Production in the Crentex Rorthand Area," (Unpubliahed Matero

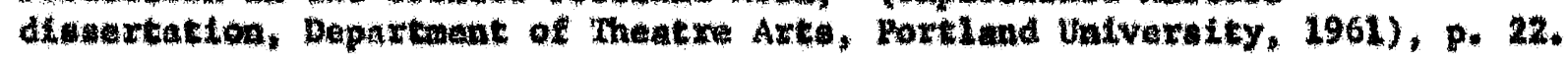


Univers ty of Portland

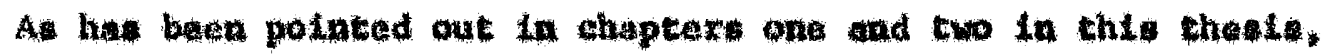
drama Introduced through presentation to almentaxy children has ereat value to chilurea. They gee plays one to life tor them. They can partickpete vicertoundy in sypathetic participation with the character in the play. Hare they aro able to experlence grluf with-

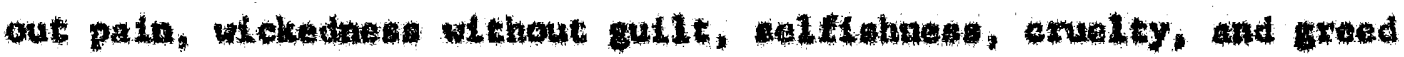

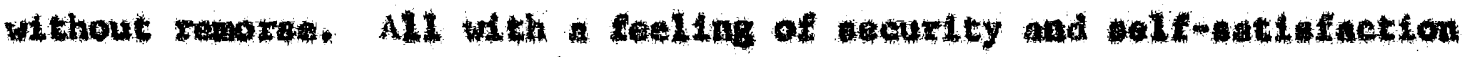
at the Lnefght gatned lato other and better underatendins of thenselver.

Alone with the viewing of production by children is the concept

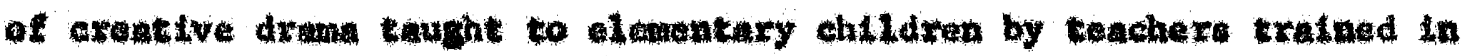

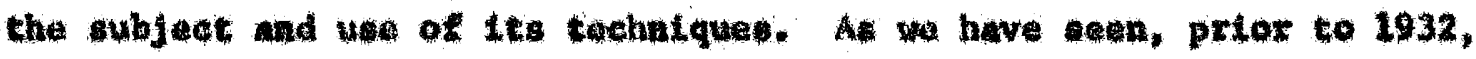

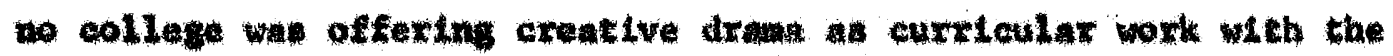
exception of Hidifred Waxd's oxa conxse Noxthwentarn Untverstiy. It was outstanding in the traindas it offerod dratatce leadars. It epphastad partieularly the correlation of the are in lementary and juntoz high echool prograns.

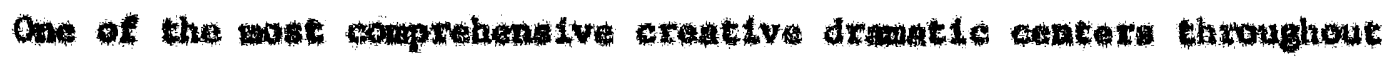

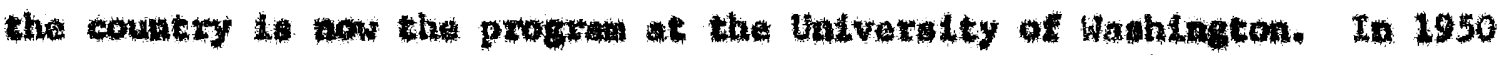
the oolleg of education ot this Uatverstcy made the ouree in eteative dramatic mandatory for an elementary chool certifleate for the

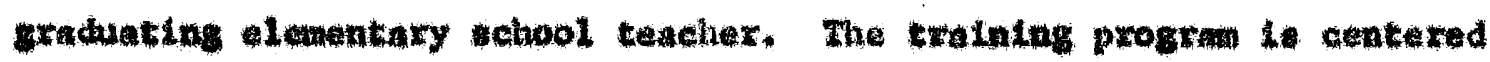


on ative partictpatlon. studente atperlence and observe crestiva drowatie: for two quarters bofore they are gulded into teaching this art to children. The future teacher. are taught to ronlize that dxand, Inatead of just batmp "fun", look thamply at Itfe and ovaluates and

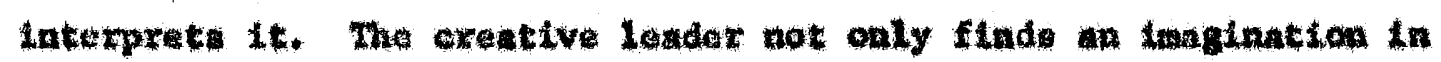

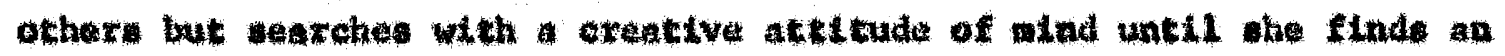

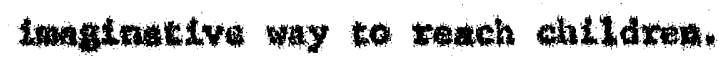

Wth these hopes in mind, Catherine Roberts has devolopad

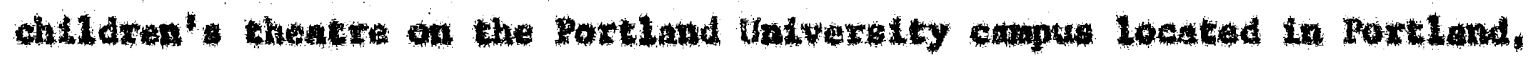
Oregon. Tart of the Theatre Arts Prograt at the Ualvexolty of Portland,

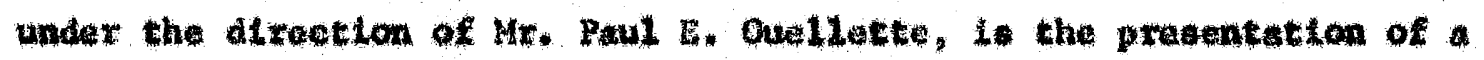

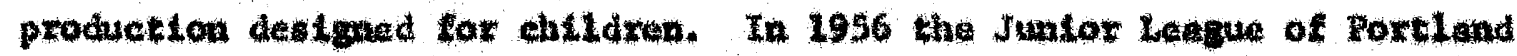

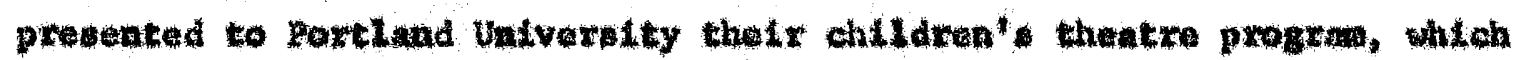
they had bean tourime to the Roxthand Subools for maveral yoarw, the

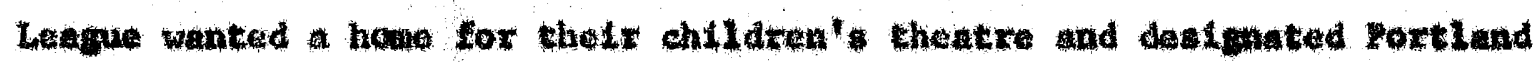

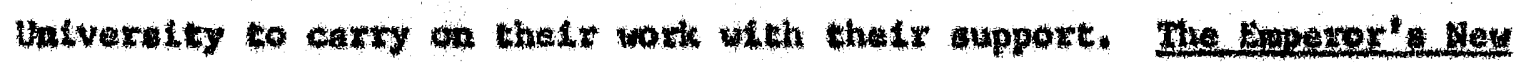

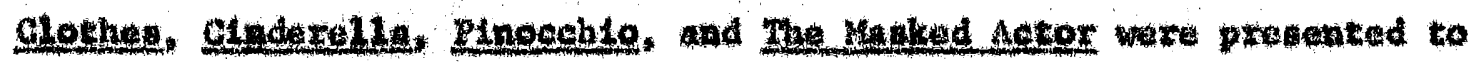
achool ta the Portland area on tour from Portland University wh the support of the Jumber Leaguc. In the fall of 1960 cathertne foberts bogan a trend tren ohe vrote for her mater' chats an oxiginal play

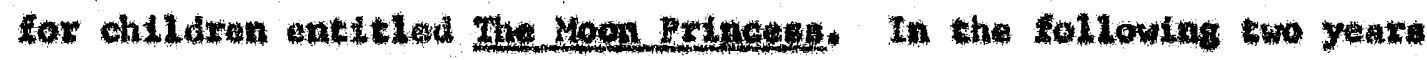

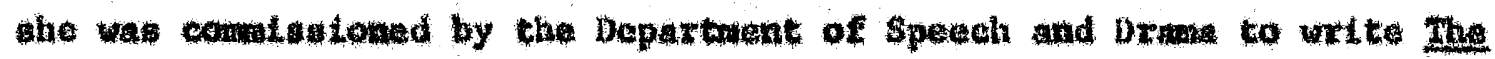

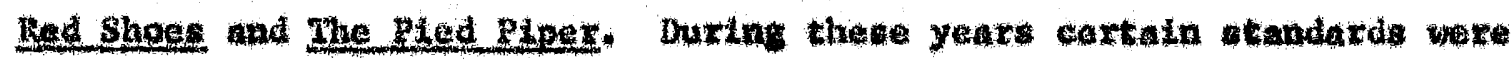

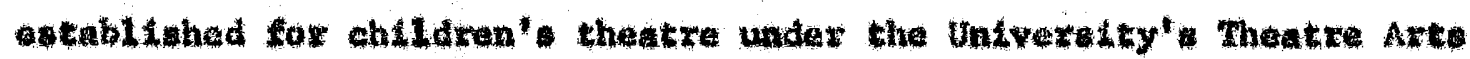


Program. The Moon Princess, st111 under the Ilnanetal support of the Junlor League, toured fifteen of the Portland Schools, Including many schools whose chlidren would not otherwise have ever seen IIve children's drama. The sets, designed by Kermit shafer, were on rods with curtalns. A new eurtatn was used for a different scene change, making them very tranBpertable for the tourlag group. By 1961, the project was left totally in the hands of the University and the Junior League gave no more 4tnanelat help. W1th the touring of the 1961 production of the Red Shees. Written by Mrs. Roberts, changes had to be made to keep the productions golng. Solleteling for the booktng of productions was made through elubs and schoole. The ehlidren's preduction was played two wek ands at the Univeratty Theatre. The sets becane Feverbible fragment sets to be uged at the campus production and also toured. In 1962 Mrs, Roberts wrote The Pled Plper, besed on Robert Browning's story, and produeed it at the Untversity. In 1963, Andrecles (The Prince that Became a Lieg), written as a Master of Fine Arts ThesLe, and In 1964, Pedro and His Wadte Bex, written by Mrs. Roberts, were toured and played at the campus theatre. By now, the hildren's theatre had cat to two wekk end performanees on the campus and teured sueh places as the Royal Oaks Country Club in Sales, Oregon, Illaha Country OLub, Aero Club, St. Johns Comounity Center in Portland, and Lady of Lourdes paroehial school in Vaucouver, Washingten. The children's theatre charged $\$ 125.00$ a performance. In 1964 Portland Univeralty also developed a graduate program for creative drane and children's theatre. They offered in the graduate program one course in creativitymapprectation of Imagination 


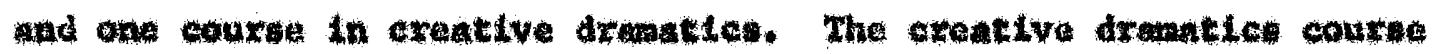

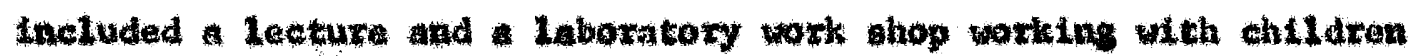

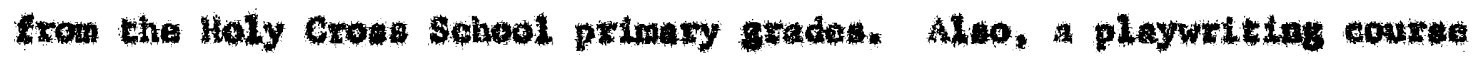
was siven olunced toward chldren* thantre. This graduate progran

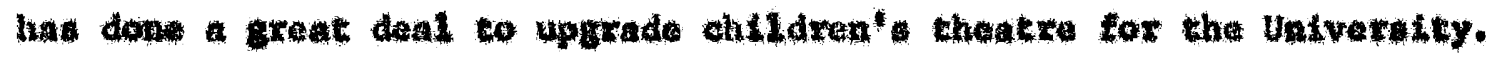
1t provides an oppontuntty for graduate theatwe now working in

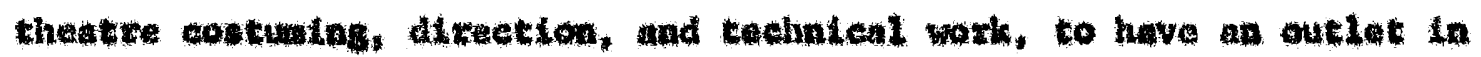

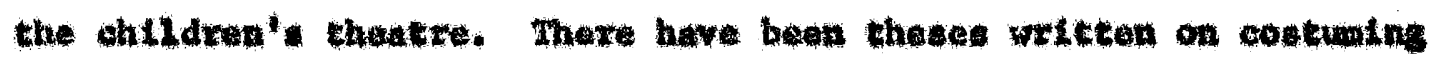

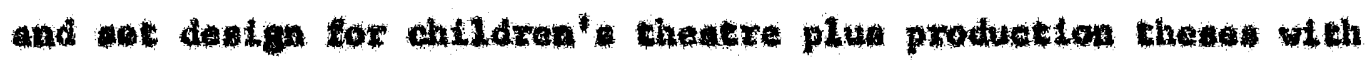

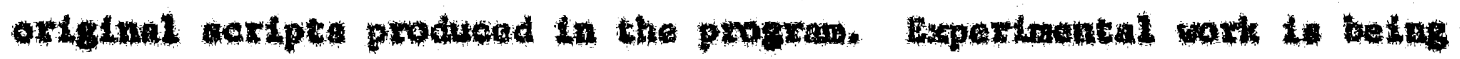

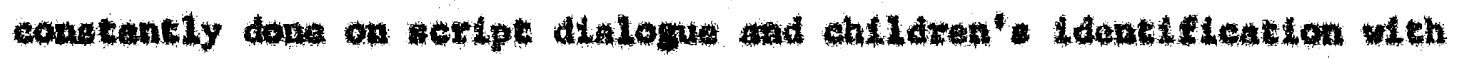

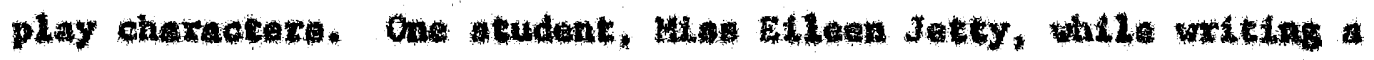

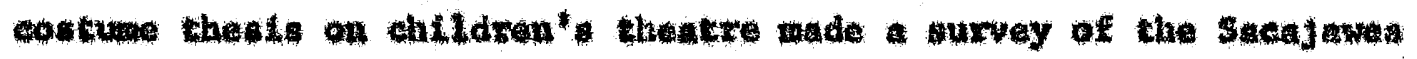

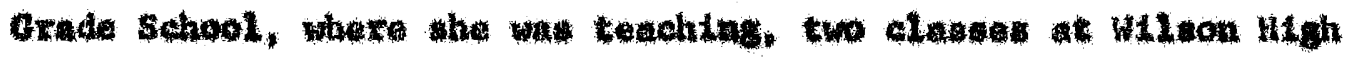

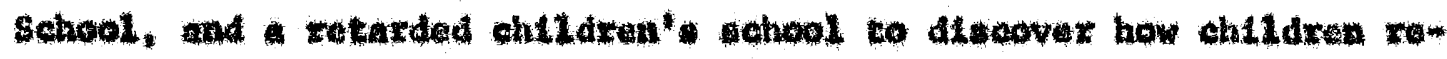

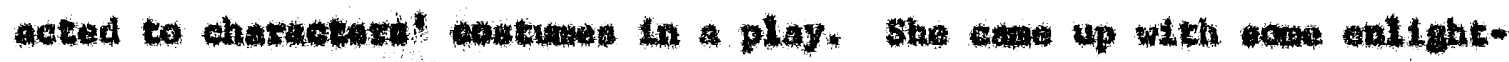

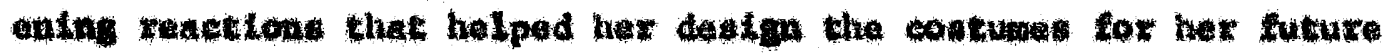

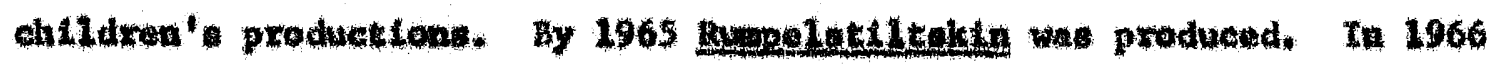

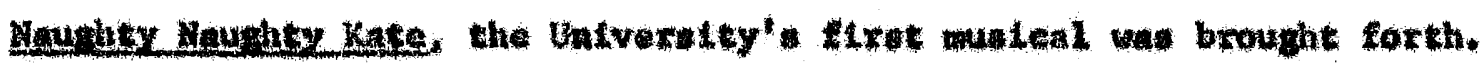

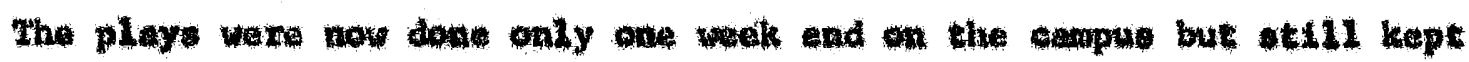

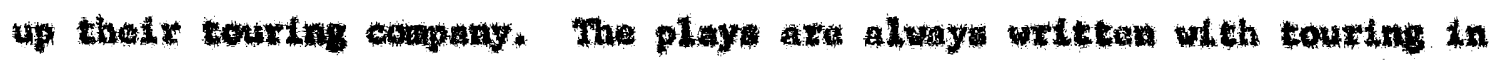

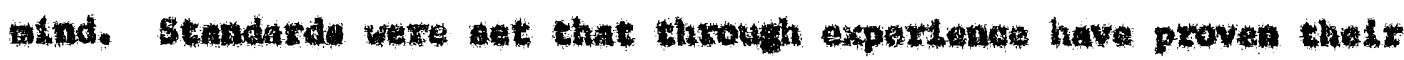

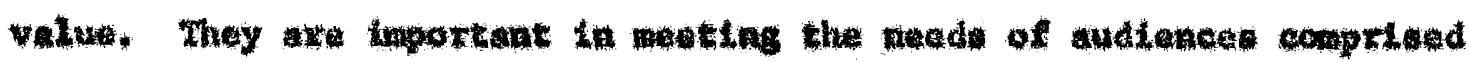
of ohildxen aga atw to twelve. The ruming the of the play is hala

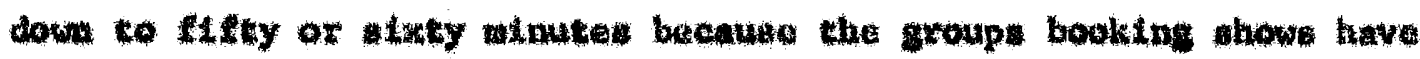




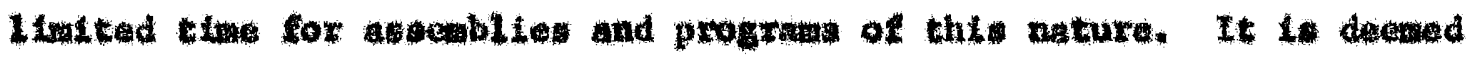
daglrable tor the cast of the play to conalet of not nore then algt

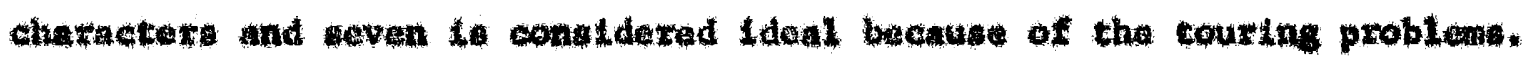
The satis ane desgned quite thoxible, wo that although omate at the Uadveritty theatre produecton, the set can be broken down to tour and not lone the qualky of deolgn. Audlence paxtietpation lo woxked into the extpes.

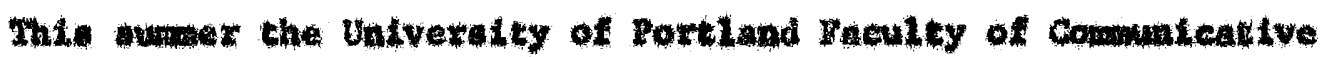

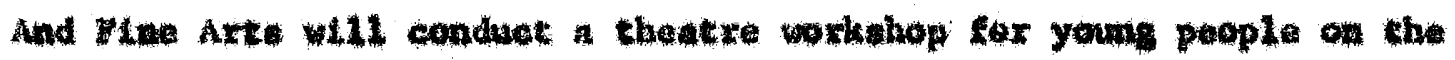

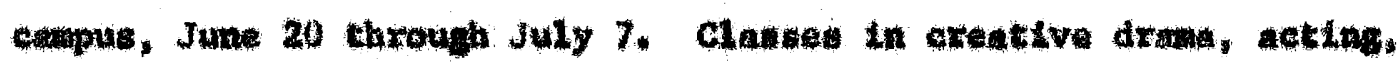

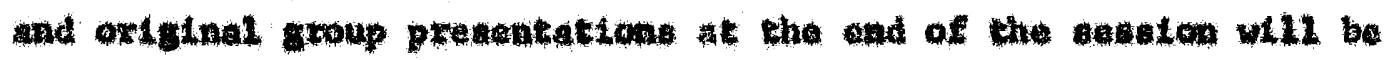

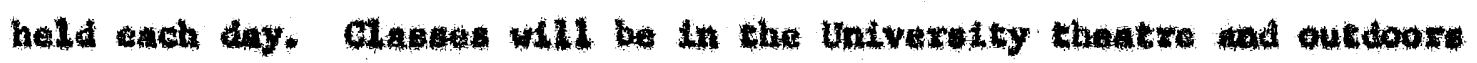

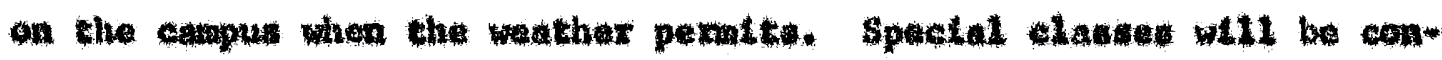

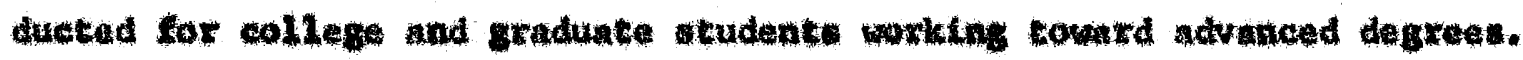
Mr. Catherine Boburte, who has wrtton playo tor the children's

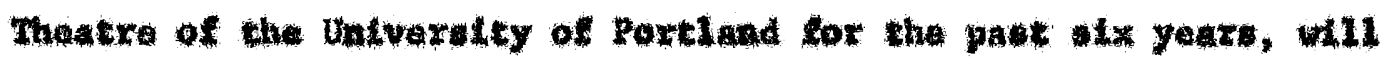
onduce wentane in playntitus.

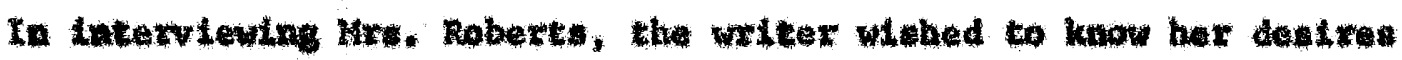

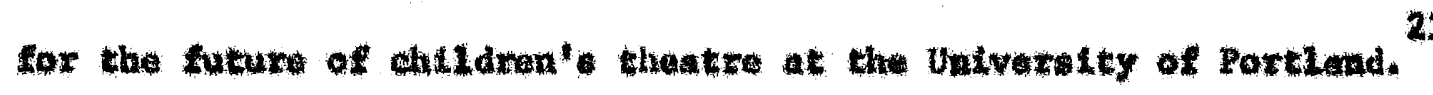

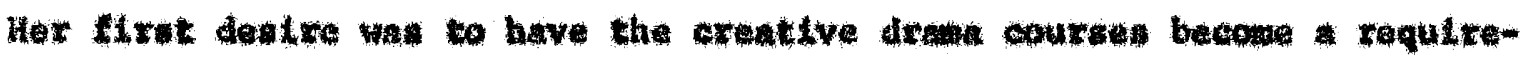

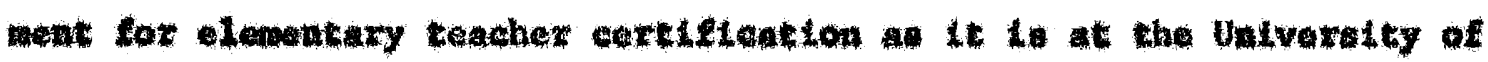
Wankington. Alvo, whe would like children's drana couraes to be offerud

23 Iatarviaw wh Catharine soberta, Profemor of Theatre Art, Dortlund Univeratsy, June 12, 1967. 


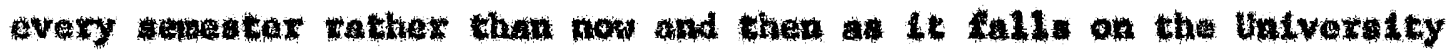

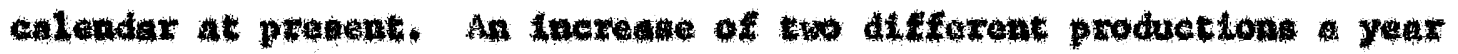

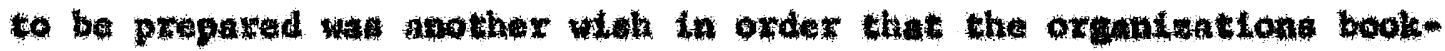
Ing the play would have a valety from wheh to choose. Last, becaume

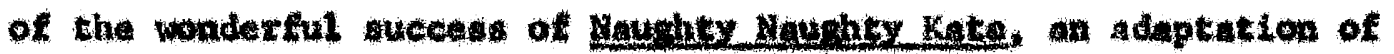

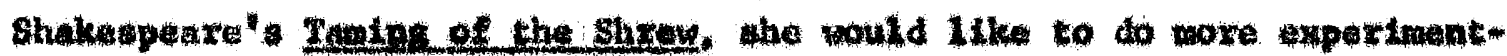
Ins th tha alatelen tor children. This play, onjoyed by both adulte and

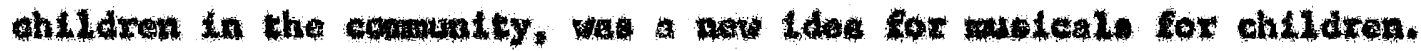

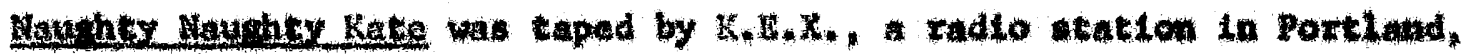
and ant to the Nathonal BLInd sehool. Here It was so gxaty apprechated

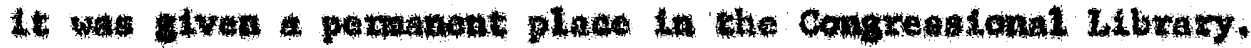

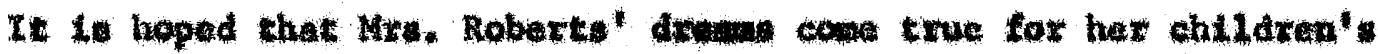
theatro:

Children thatre t: cextatnly not the onty andwer. How"

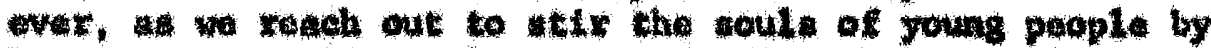

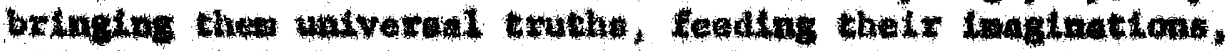

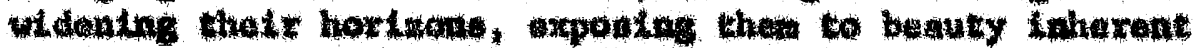
in the Lutons of all the arte that enorge in flue thent-

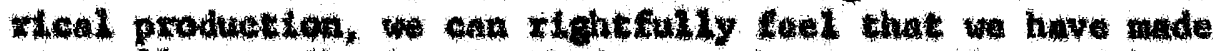

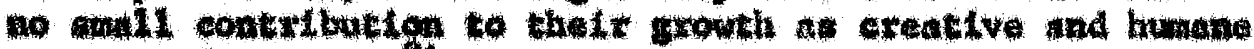
newbers of coctetcy. 24

24

Davle, pa. at, p. 297. 


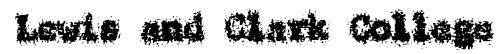

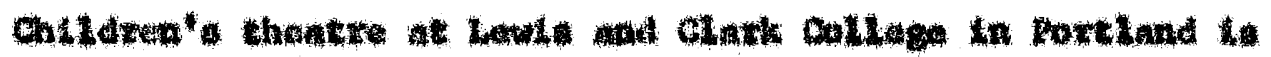

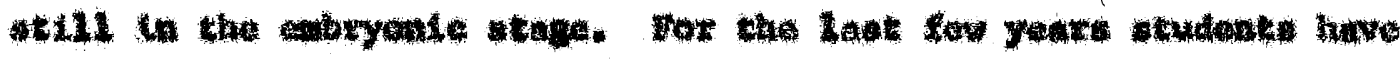

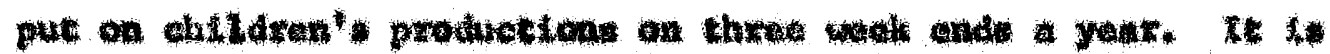

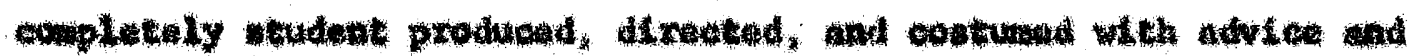

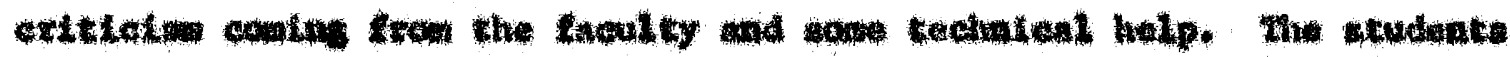

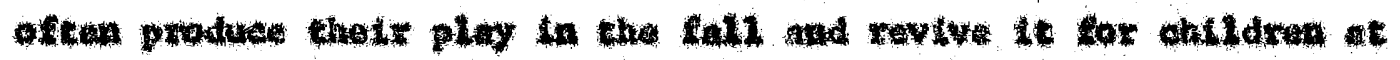

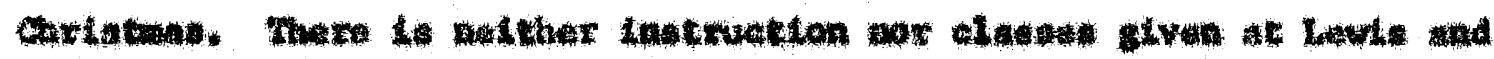

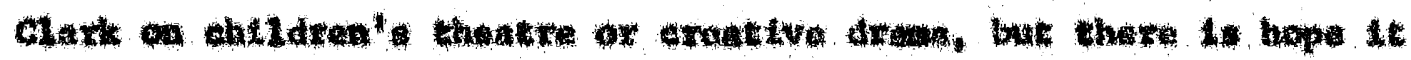

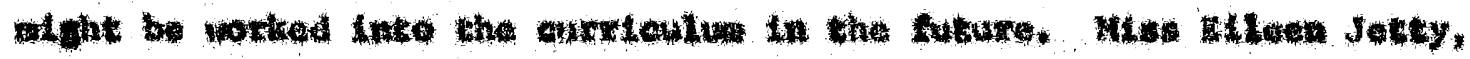

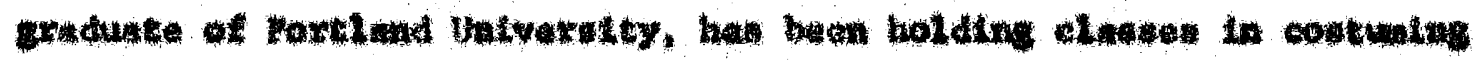

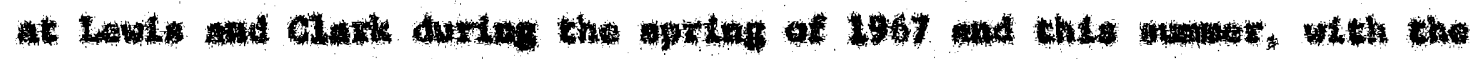

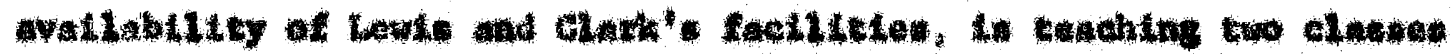

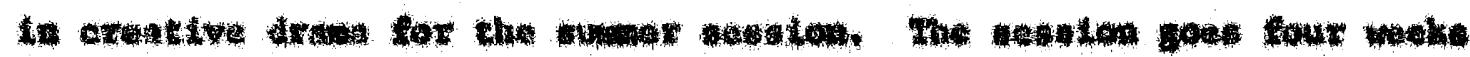

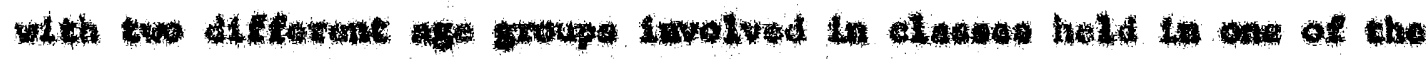

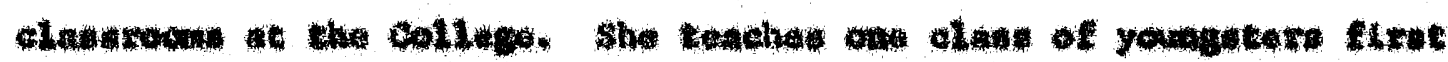

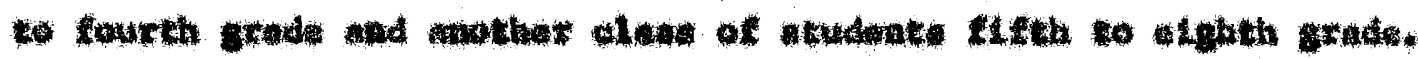

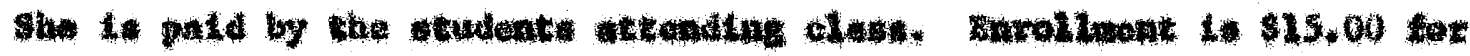

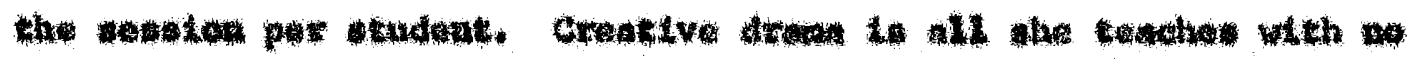

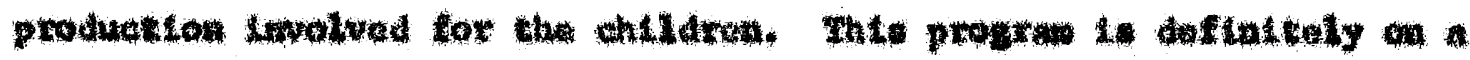

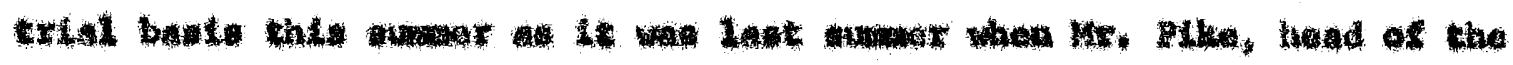

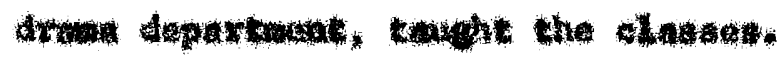




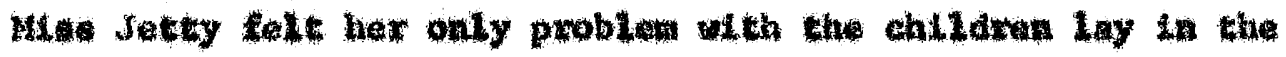

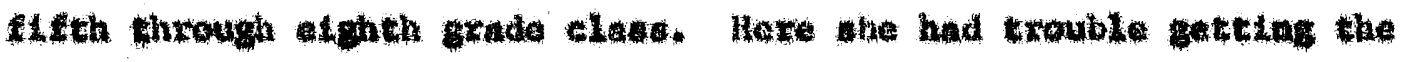

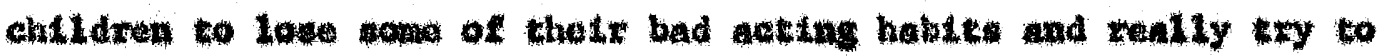
wo whatr niade in cractive woxk. 25

25

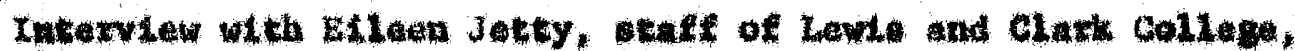
June 6. 1967. 


\section{Fortland Juntor Loaguc}

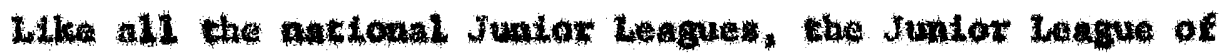

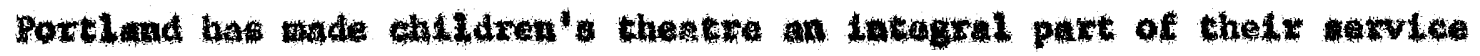

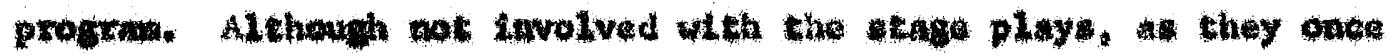

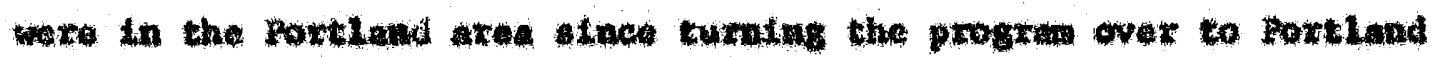

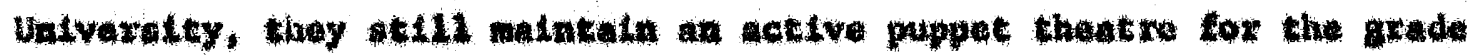
echool chlldrow of the arwa.

In 1948 the prograb bogan very abstiouely. Mr. Hallace from

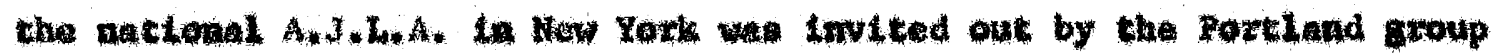

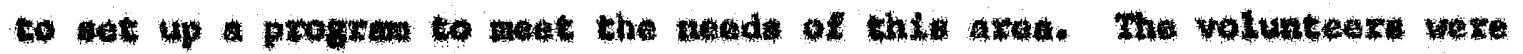

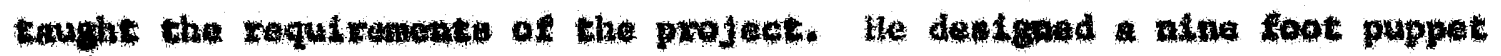

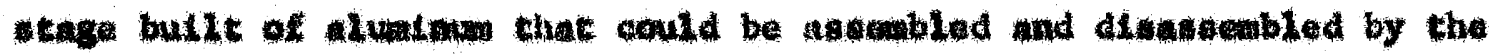

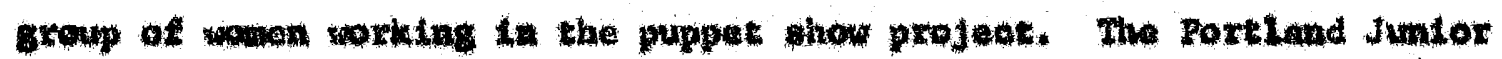

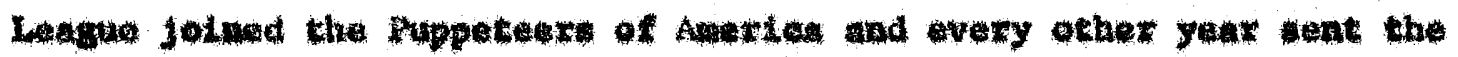

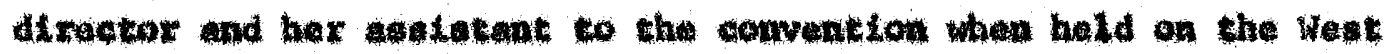

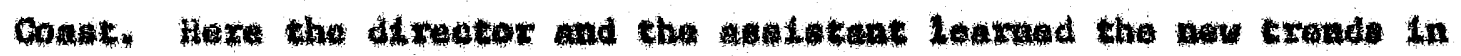
puppotery and whatud product Lone frow all over the nathon. In 1950 the

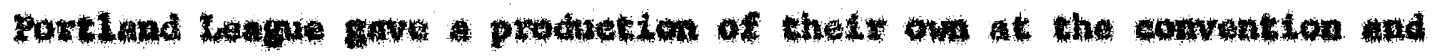

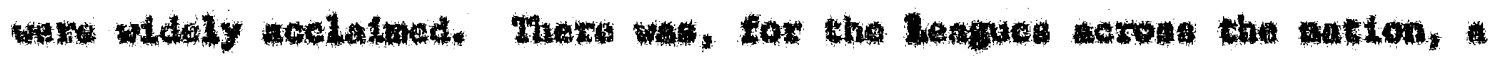

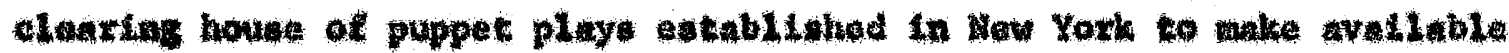
ready made extpts tox that varlow stoupe.

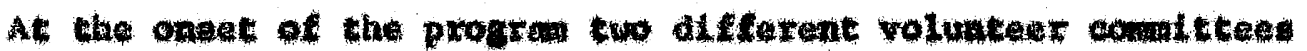

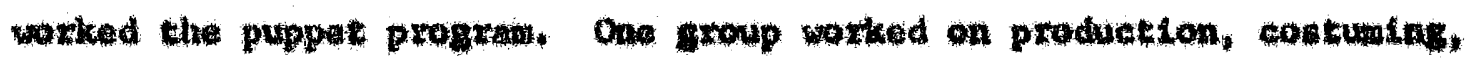

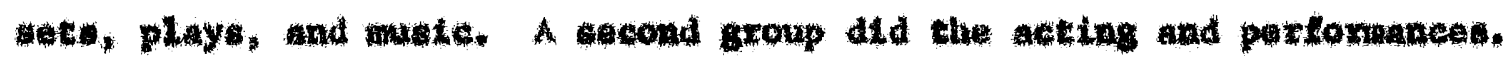


As the years went by, Lt developed into one group of stx or seven handling the whole project.

Now the stx volunteere do the production work in the spring. have rehearsals the following fall, and go Into thelr production in Detober. The directox sete the year"g ochedule of performances by contacting achools in the area. They generally perform for from forty to sixty schools year depending on thetr casts. In moxe recent years, as the demand of productions and performances hat become note time consuming, they double and acmetimes triple cast thetr show. There 20 no charge for the puppet show: and it 1 glven to any school that destres the performance. In wewe of the larger schools two performances are given back-to-back to give all the children in the school the opportunity to see the play.

The soripts are kept to five characters and one person tox musie. They are wrten for not longer than twenty-five minuteg playing time. This program to the nost expandive in the Lengue budget because production costs are so high. They budget $\$ 900.00$ a year for the operation. Ia 1964 Mre. Levis scote, ${ }^{26}$ wo interviewed an June 19, 1967. becue director of the puppeteers. This postion is usually changed each year. Because of hex kan Interest and ability on the aubject of puppetry, she has remained at adusor to the program until the present time. As the dinector, the broadenad the scope of the League $s$

Intexview wh Mrs. Lewti Scott, Rortand Junior Lague Member, June 19. 1967 . 
productions by giving performances to the handicapped children of the area. It was most enjoyable to the mentally retarded schools and the cexebral paloy groups and very gratifying to the puppeteers. In the directing of the plays she found much to be desired in some of the scripts. She started to write her own. By choosing well known plots such as lansel and Grete1, Rumpoingt11tskin, Jack and the Beanstalk, and CInderella she assured her group of an understanding audience. Children are 80 captivated by the mechanics of the puppet that a complicated plot is impossible for them to follow. Also, because their audiences were so large, she needed to have much more emphasis on action than dialogue. Her main objective was weeding out the details of a plot and giving a very broad twenty-five minute pley. Her plays were widely accepted by other League groups throughout the United States.

Mrs. Scott's destre for future work for the puppeteers is in making the puppet show a more creative intimate program for the children. It is becoming more difficult to recrutt volunteers for the program because of the demands on them. She would like to see groups of two women going into the classrooms in the public schools and working stories and plays out for the children by more relaxed creative teichnique. They could also expand to nursery school age with this simplified method of puppetry. All they would need is a box of puppets, two eager and enthusiastic puppeteers, and an exciting tale to tell to bring the wonderful world of puppets to the grade school children of Portland. 
The Portland waxth pusur

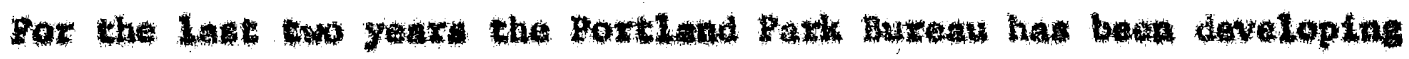

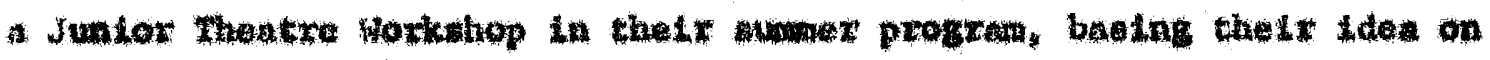

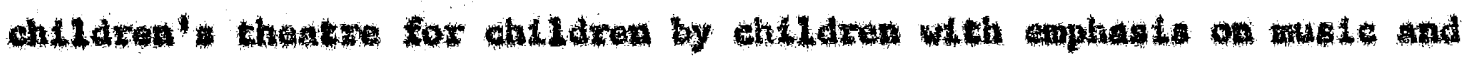
dande. Frior to this new prograw, four yeare ago the Park Bureau otarted their high school and yound dule acting group called the

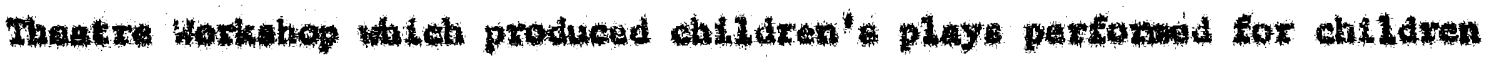

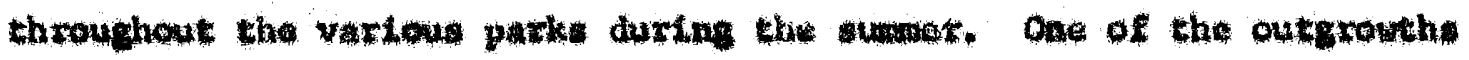

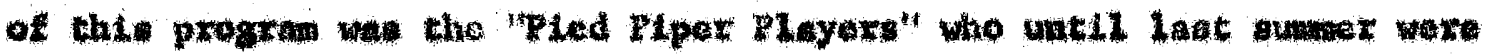

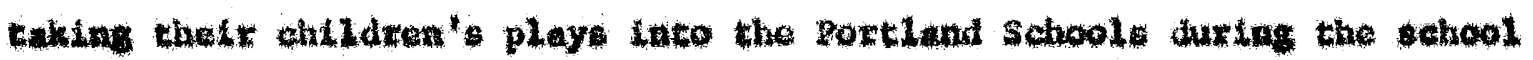
year.:

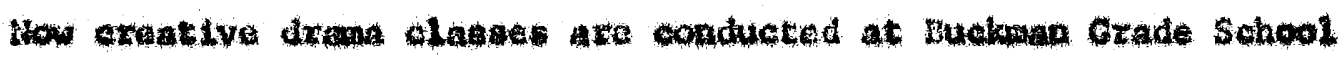

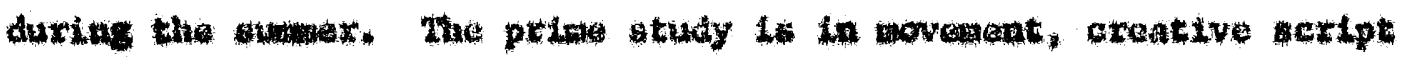

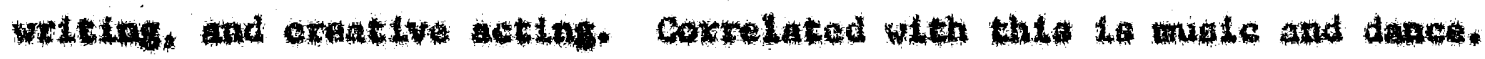

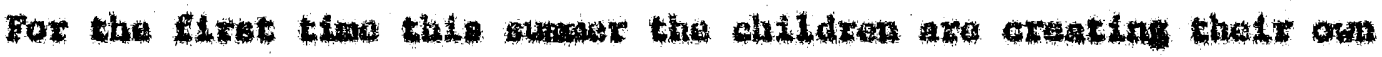

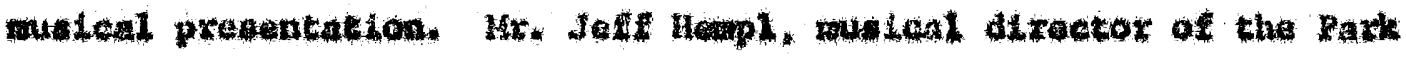
Burean, woxks elogely wht the dxidxen so that the mute for thoix

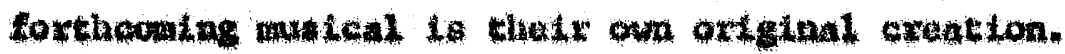

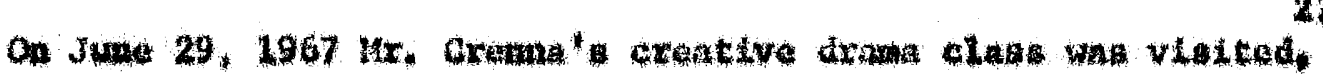
suckon Grade school. The dass neluden chlldren from alght to

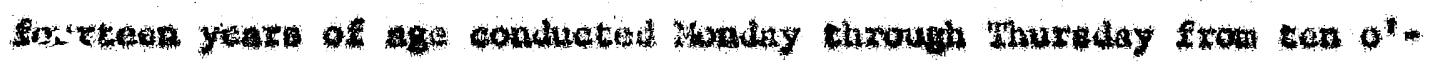

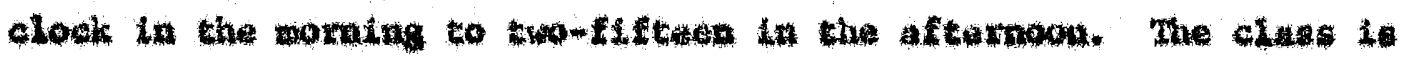

27

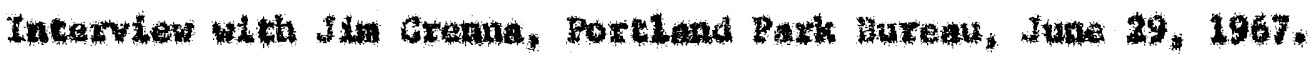


tree of charge and open to anyond intereoted. The clate rums trow the wadle of Jume unthl the and of July. A production af the chlldten"s play is gun July 20 to parents ad othor welcomed viatero.

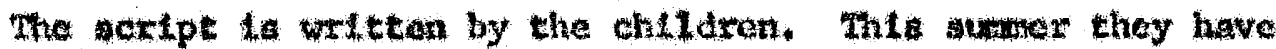

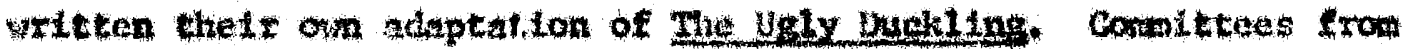

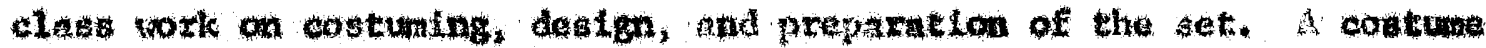

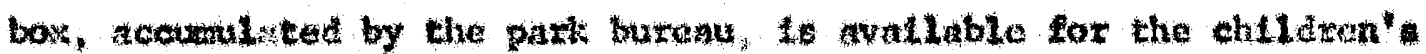
use; but they are completely respondible for contualng the play. The set to made of butcher paper covering old that for the backgrouma but the properties an found or wade by the set comattee. Another comatto is in charge of publicity and programe for the production. Euctuac

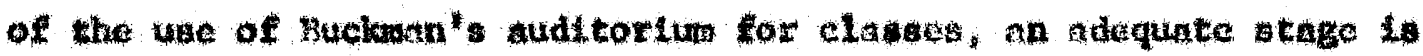
avallable for the chldren' une. Therefote, they have the advantatge af Loaming 1Lghting cechntques.

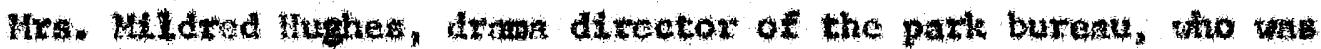

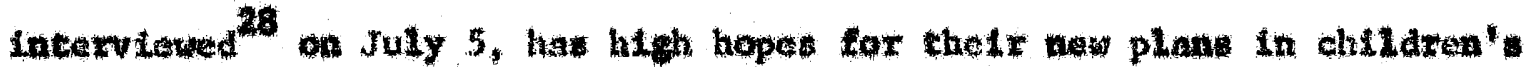
theatre by chlidren and hopes to develop 1 t evontually into a winter

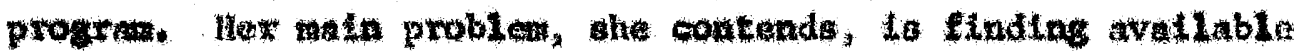
teachers in the aren interested and tralned in ollidran' dran.

$2 x$

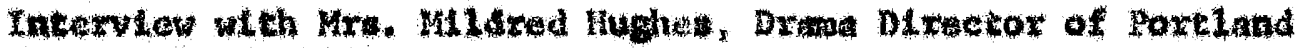

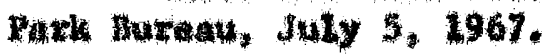




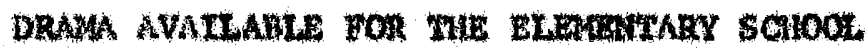

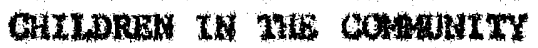

\section{Paztland Junlor Civio Thentre}

The gecoud area of chlldran' drama boing offered in the porthnd

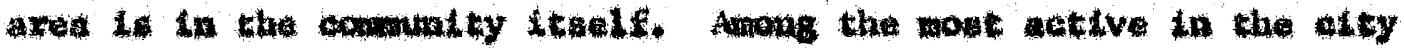

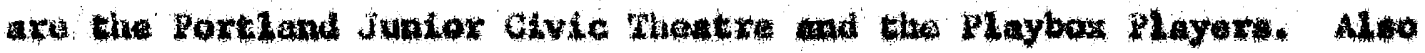

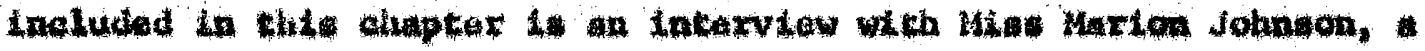
Roxthad childran' playwingt notad throughout the United statat fox has chlidran' plays.

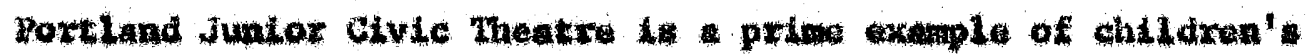

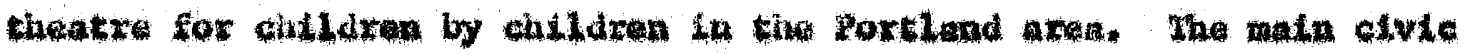

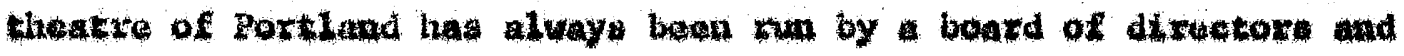

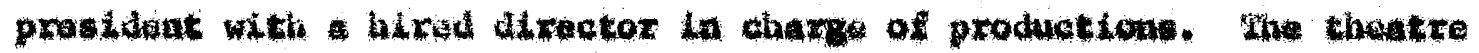
group rowad tho city for maxy yeare watil it wade its howe at the

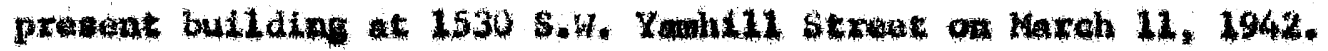

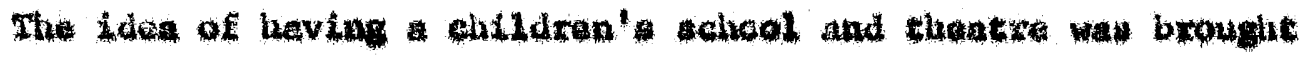

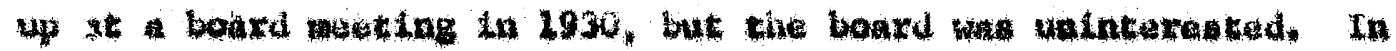

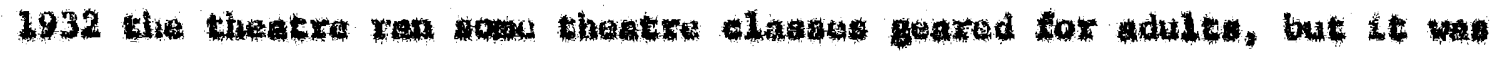

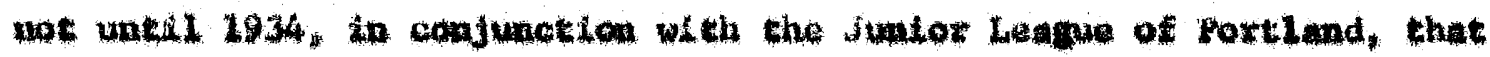

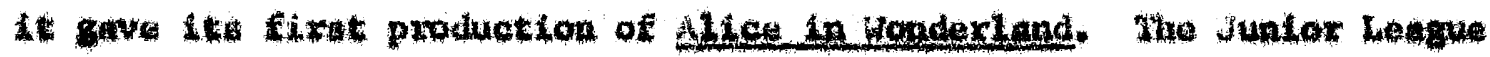

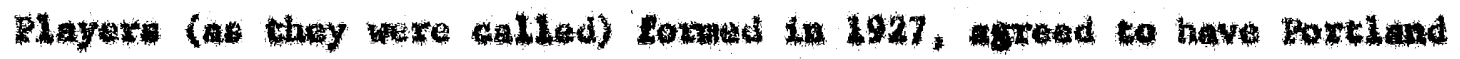




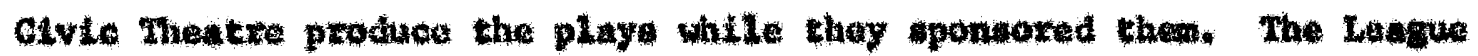

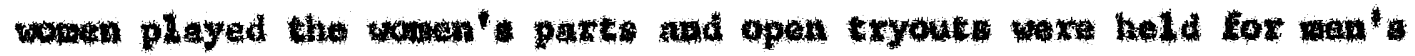
parta. A fow your later the chlldras frow the lower wethot of the

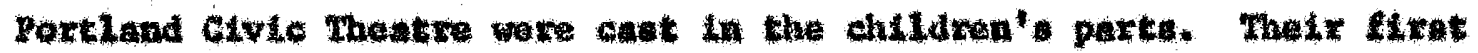

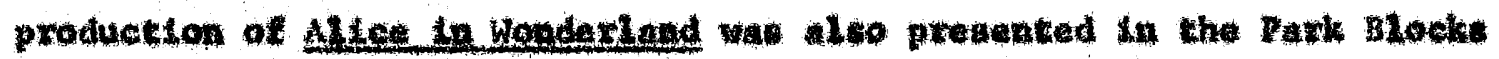

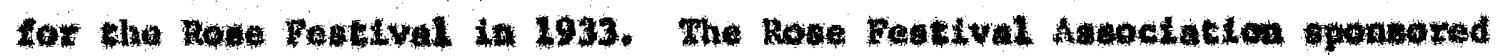

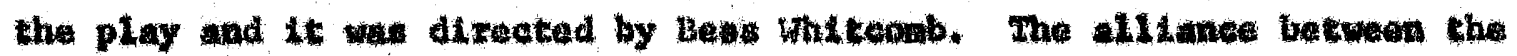

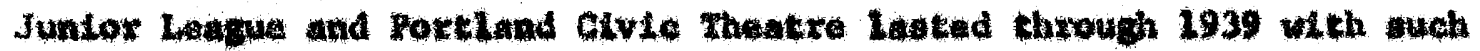

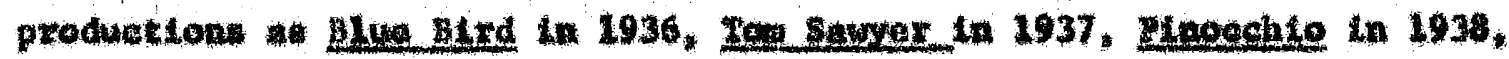

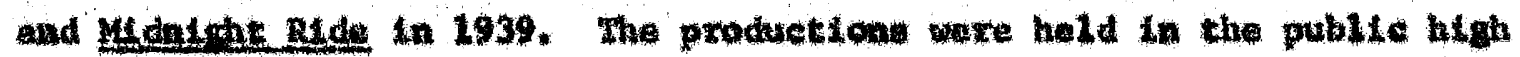
senoole. the ehuldras were brought in by busen. In the wasen of 1936 -

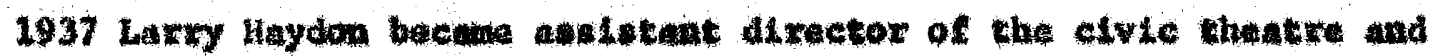
atarted the devalogneat of the lowar scliool progran at the theatre. A

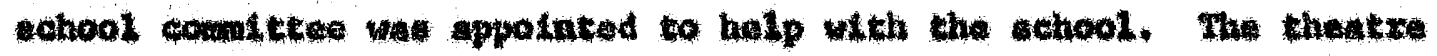

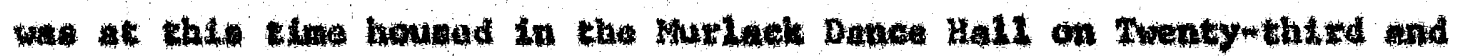

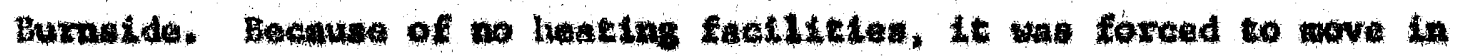

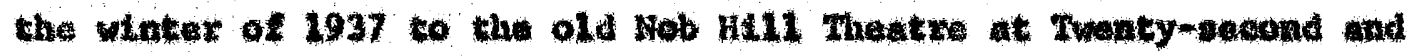

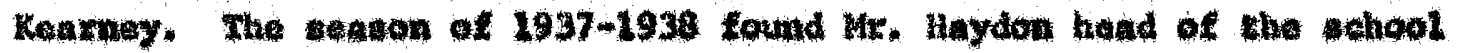
and Den Marye Alrector of the hentwe. Here agaln. they had howo-bane

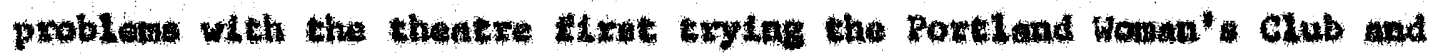

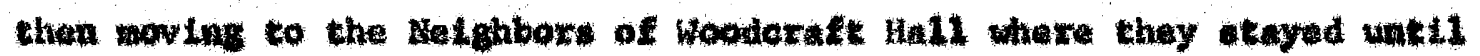

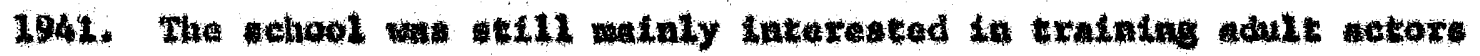

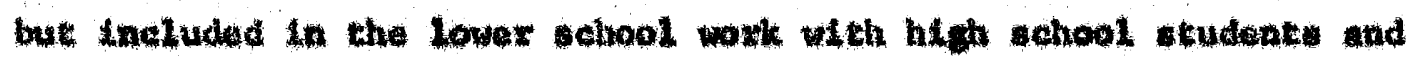
Loth graders. In 1930 the lower achool produchd one play. Lady

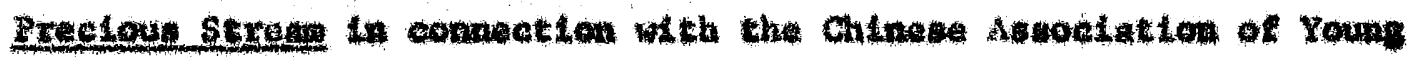
people under Hr. Waydon's alrectlon. 


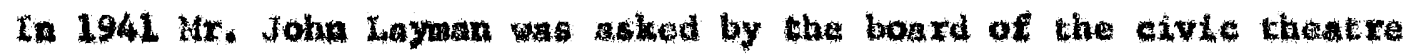
to formulate in whiting the gonla and ime of the lowet achool and plan for 1to curriculum. Mr. liaydon had left the theatre in 1939. On March 11, 1942 the civic thotre at last had home of tro ow where it thill reades. In the campaign for fund for the nev building in 1942 it went out publicity bxochure proniaing to do the following for the ehildran of the Porthand area*

1. Open the theacre whout chaxge to the children of Portand at Least onee month for production of chlidren's theatre from tho children' alatian.

2. Produce onet every yoar, play that wa required reading for the high tehool studente of Bnglitioh and present without cost to the children of Porthand and the outiying areas.

3. Rrochuetiona of chlldrwa' playe would be caken to the Crtppled Guldiren sehool, school for the Blind, U. Veteran" Hospital fxe of chamgat 29

The Juniox oivic theat really came into to own in 1944. $51 x$ productions ware produced throughout the chool yoat, and a anor

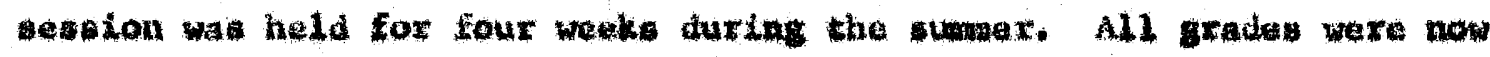
included in the thentre chool. The first staton conisted of cinderella,

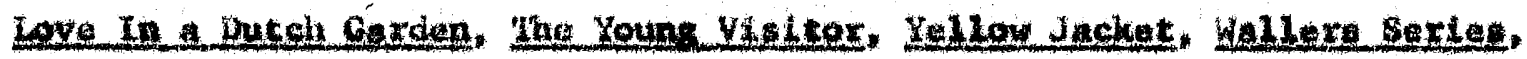
and Erunella. The costeming ond cechaical work was all handled by the adult theatre's technical atrector and contumer. The old genool comitce was re-ttlod the Education Comatter, and the title of Juntor Clvic Theatre was given to the childzen's school and productions. The greac emphate on the lower school came at this time bocause the adult thentre achool had been alnoat entirely taken over by the oxegon Untverolty Extenston bividion. Rehearsal and school classes still wete

\section{9}

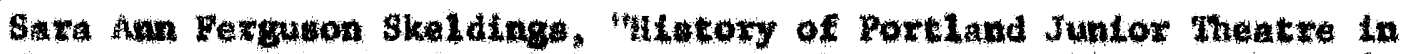

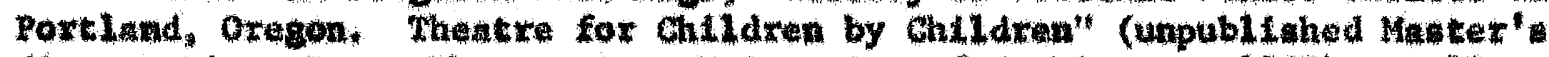
dissertation, Dept. Theatre Att, Ualvegetty of Wahtagton, 1967), p. 12. 
not hold in the thentro becauc of lack of apace. The elabses were hald in both the sehool of Musce and St. Helon's Hal In 1949 the flrat graduation from the achool was held. This graduation has con-

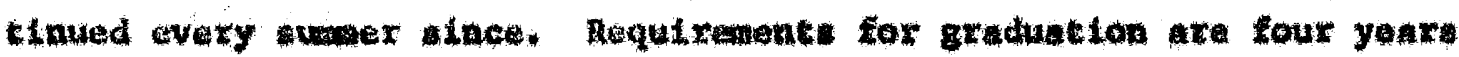
in the shool of drana Three atudente graduated July, 1949.

In 1951 Doxis Stath, who had for many yeare worked for the bllison Whate Conoquvetory until 1te cloguxe in 1946 and for many yeare been

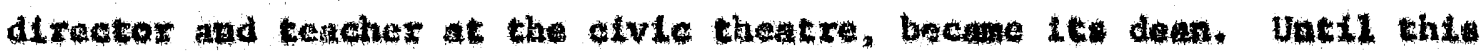
time there had been no one in charge of the chlidren's theatre except the adveation cowittoe. Hany variaties of cenching wethods and directing hawe bean aployed in the childron's ochool and thoatre, but the pamotucton schedules have been malntained. The education

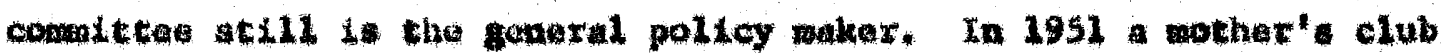
for the school was ctarted by Jin Comeron, wo had beome Jirvetor of

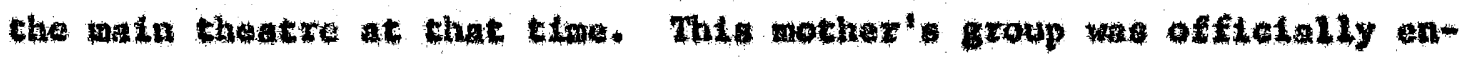
tolled Jumior Theatro Auxiliary. Tho children of the theatro cook an active part in tho Roso Retival of Rortland, not only participatins in the chlidren's parade, but giving thetr upring production at oeveral of the Homen's Rorum Iunctroons for the Sunior Roge Restival Court. At one

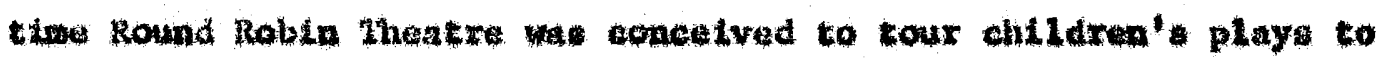
various organizations and partios. The cent, made up of atudenta of the

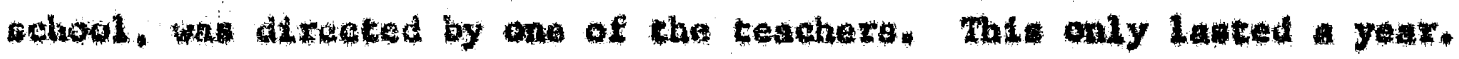
In 2956 Doris Sulth tetired sean of the sehool. Maton Johngon took hat place resgaing at the end of one year, and the position wa cllled by the preacent dan of the sebool. Marte churehil. A cocretary was 
hlred in 1958 to whe over tho atolnistrative worle of the sehool.

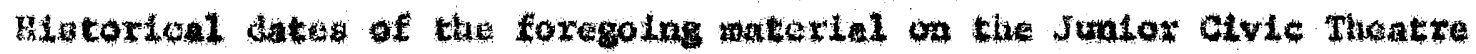

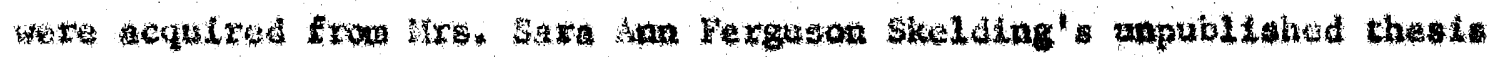

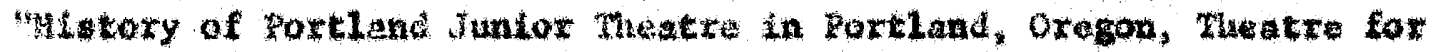

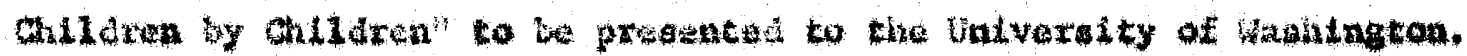

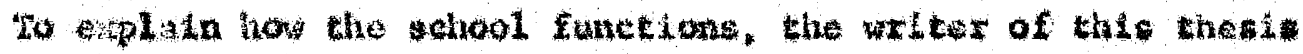

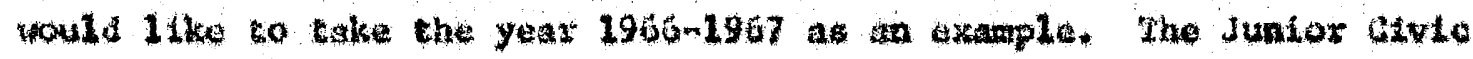

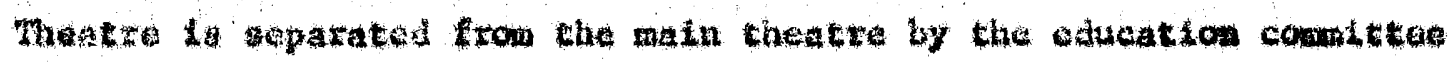

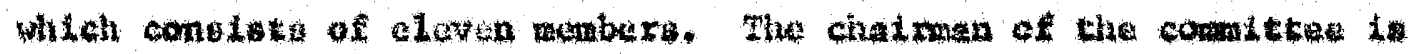
topolnted by the board of the thedtre but approved by the rducation

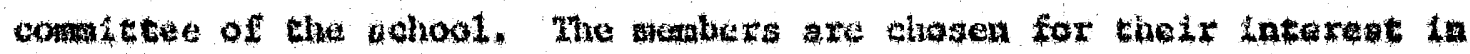

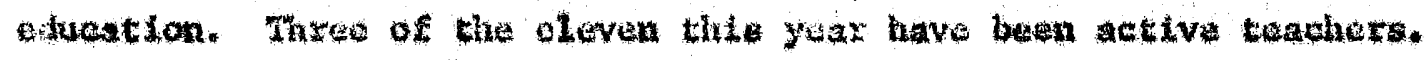

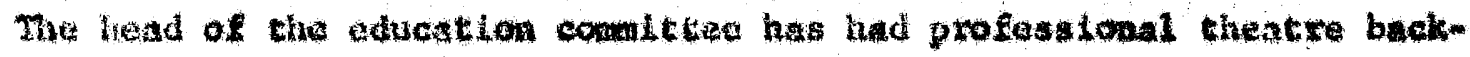

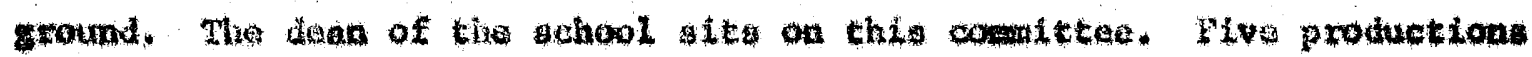

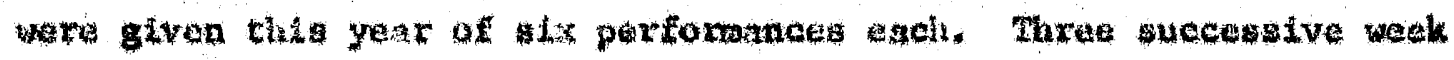

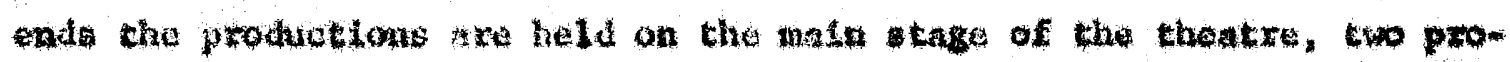
duetons seturaty whit an hour in batwen for luneh for the chlidren.

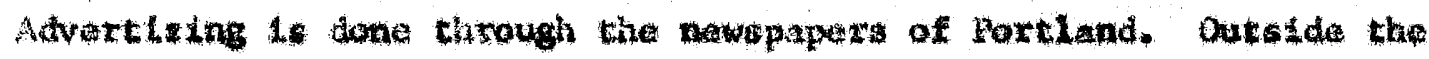
Forthad sehool Ditrice, shool can be dirtecty contacted. Schoole buy block of wate for tha performmeda and are bused into the the tre.

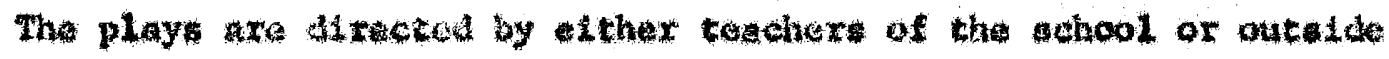

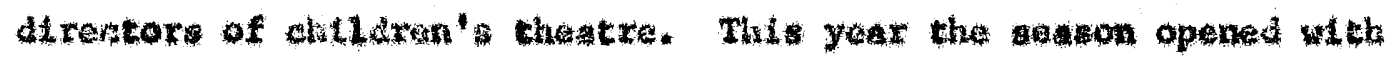

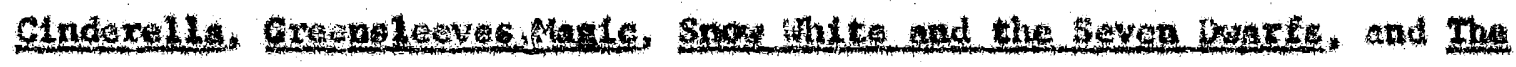

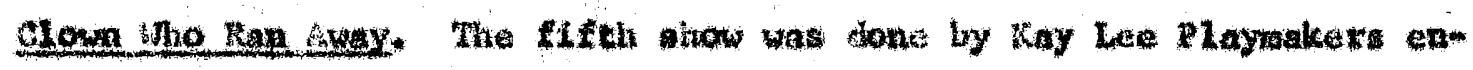

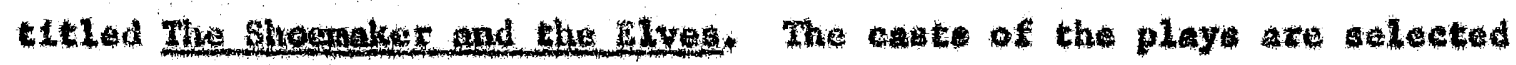




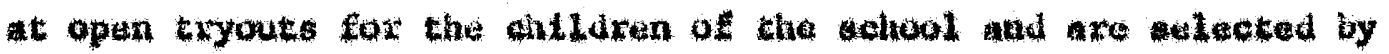

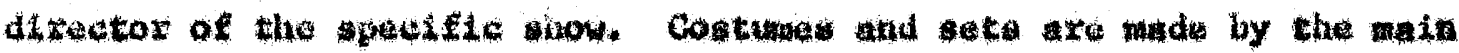

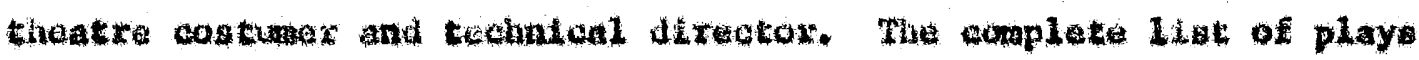

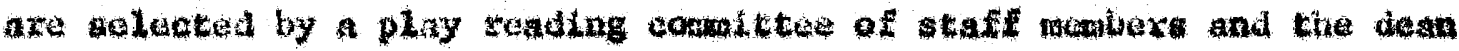
of the Ghool. Generally well known plays ard sulected because of

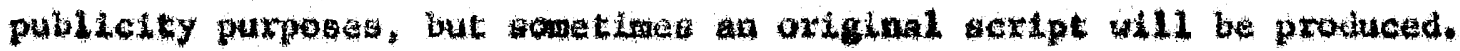
The cladou have been held the theatre atnee Rebrumery, 1955 at

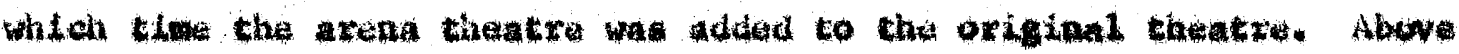

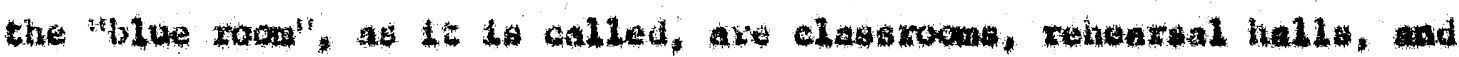

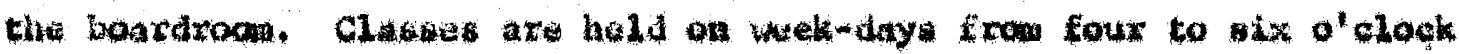

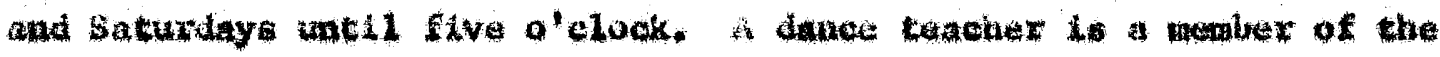

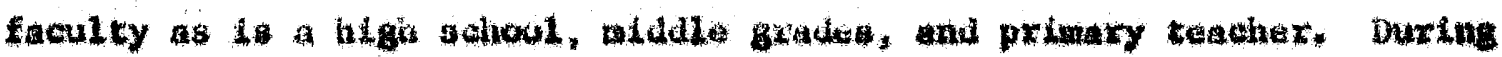
che watier murery school la hald for pro-schoolera in coordinacion

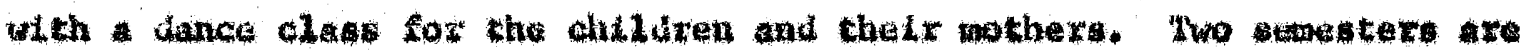

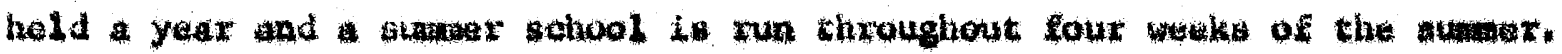

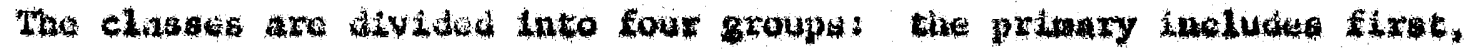

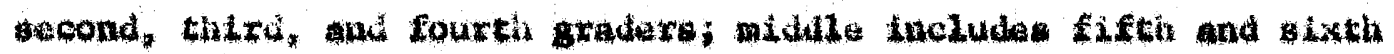

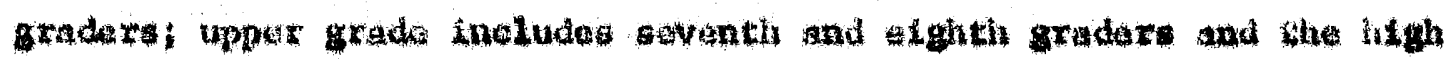

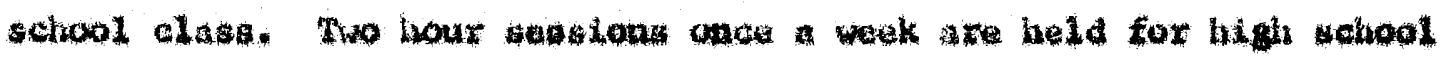

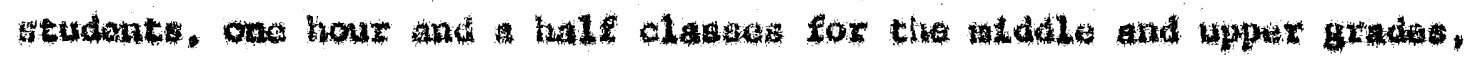

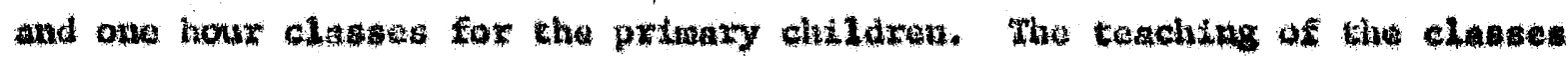

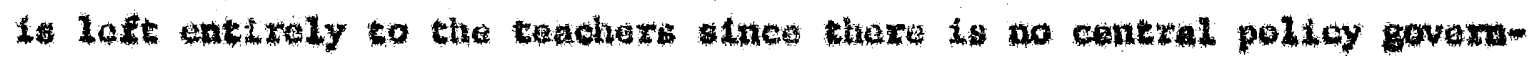

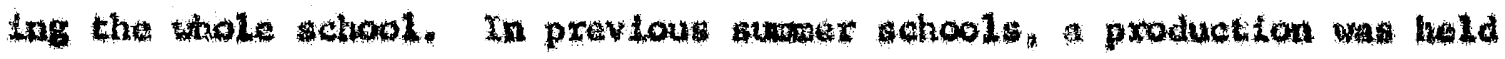

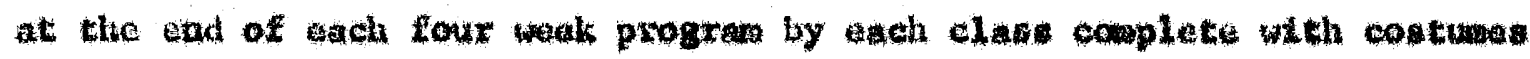




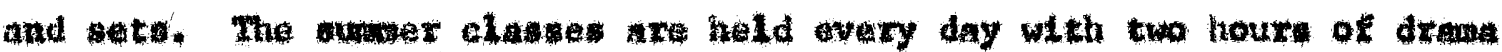
and one hour of dance hehectuled for egch ehLld enrolled ta tha mamex shool.

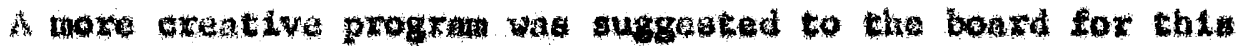

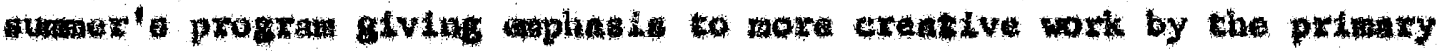
and widdle grades and large production for the upper gradas and bugh

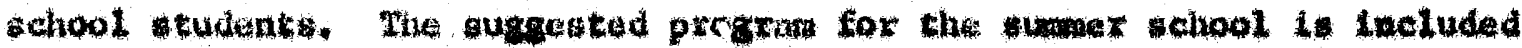

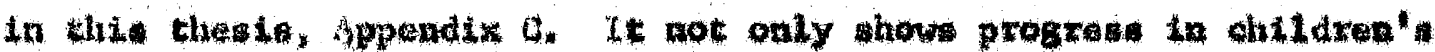

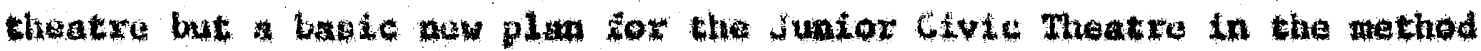
of instructing thelr strdents.

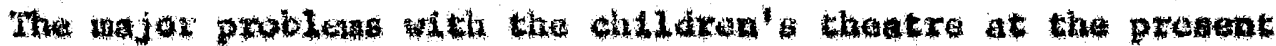
tian is Iack of coondinacion and dracton for the ochool and ita

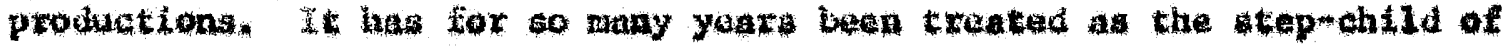

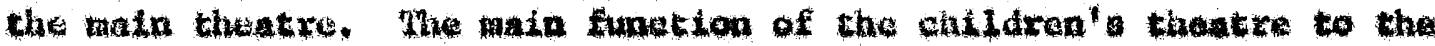

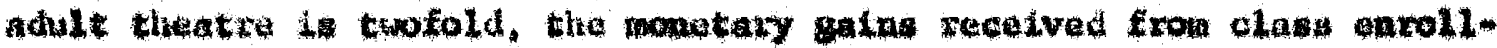
watnc and production racelpes and the tax aduction if affords the theatre.

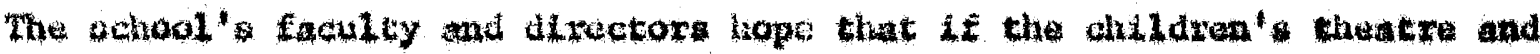

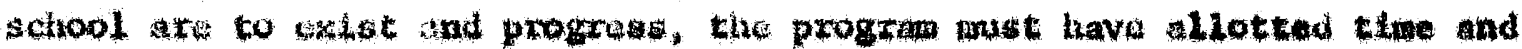

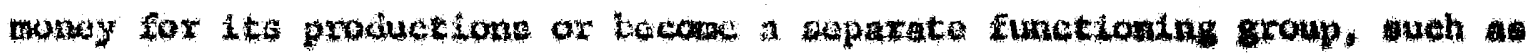

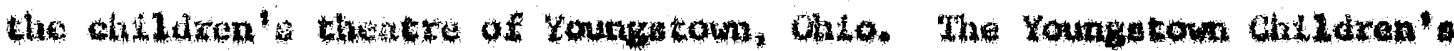

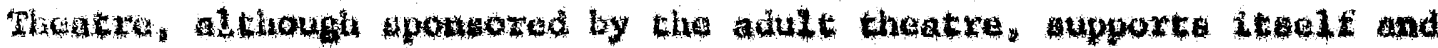

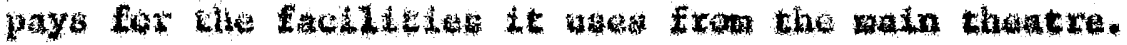

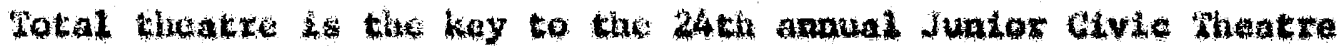

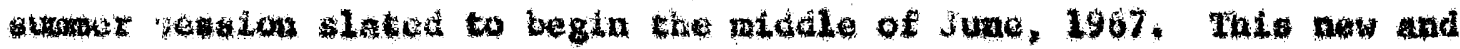

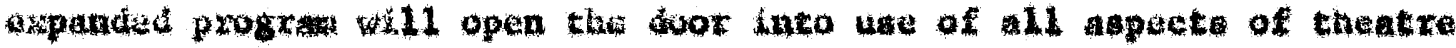


production whllo calling on both aconedlted thetructors and the Portland civite meatre profesolomal staff. In addition to the fout week awdion, tho thentre will pponso: an open conpetition tor all high

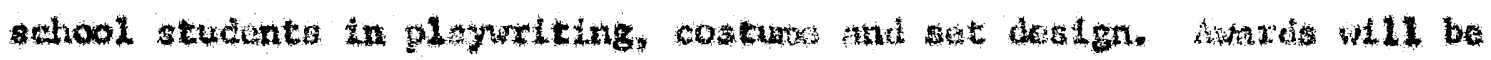

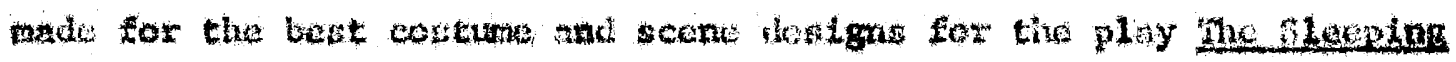

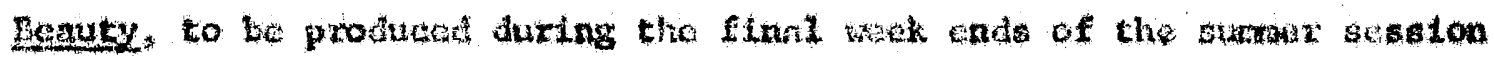
by the juntow high and high school otudents, The destgat will to ex*

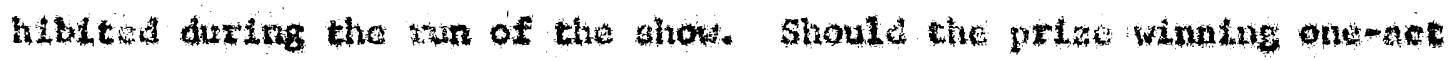

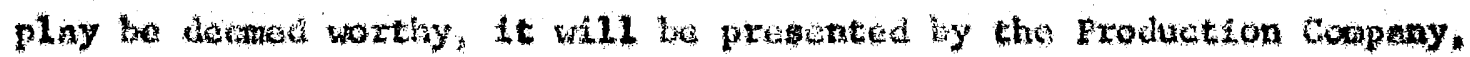
Also composed of swenth through twelfth gradis studente. Tho contests

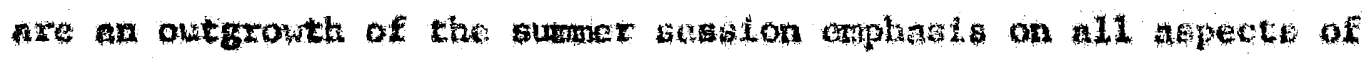

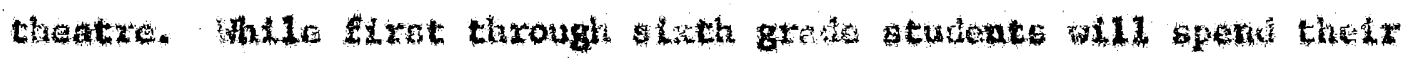

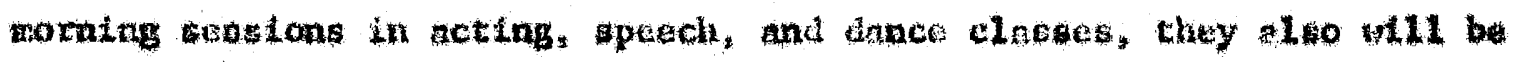

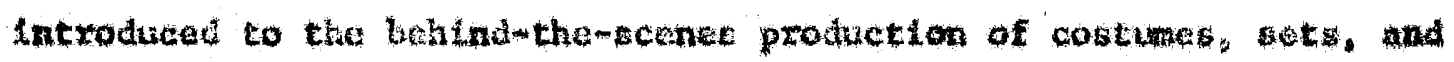
staging.

The older atudents, wo wil have an additional half hour of clabaes, wll devote thelr the to acting with one hour and altenate

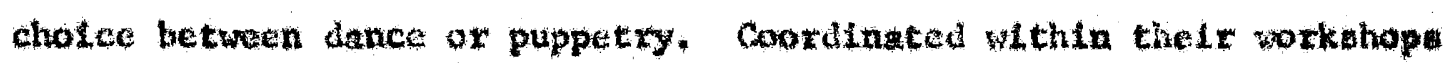

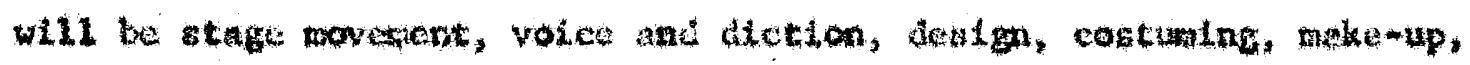
and tancing.

30

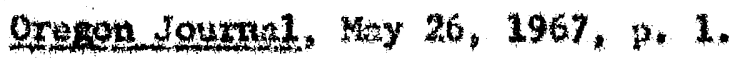




\section{Playbox Player.}

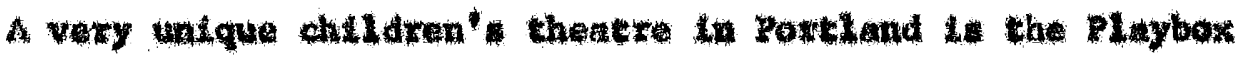

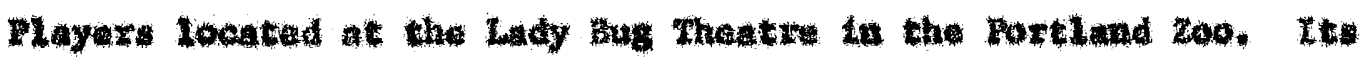

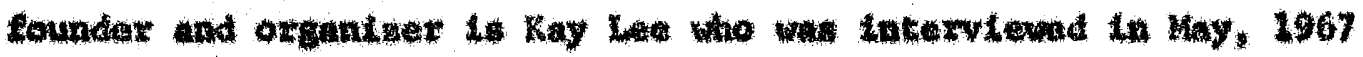

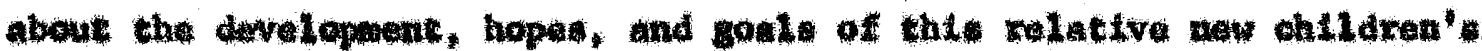

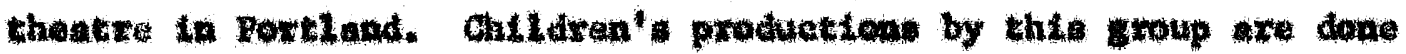
by aldes.

The Idea of this tora of theatre, the Playbost Players, atarted at promotienal selteme tor the Lloyd Center ta 1960. The Lloyd Center

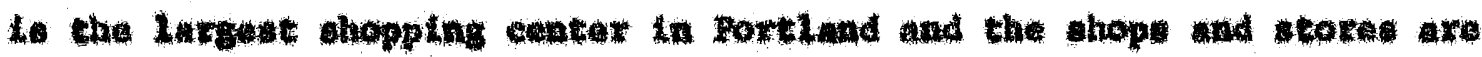
mode wailable to the customer on 3 largo mall. On this anll the

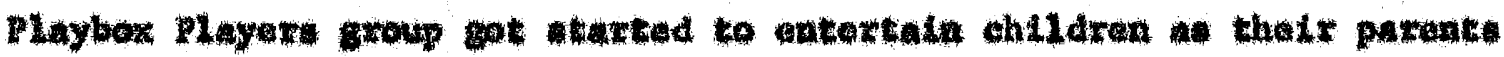

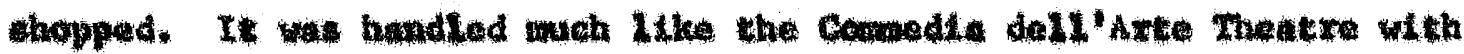

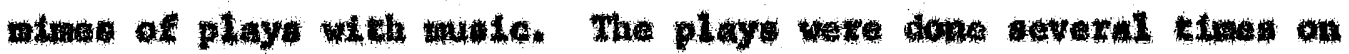

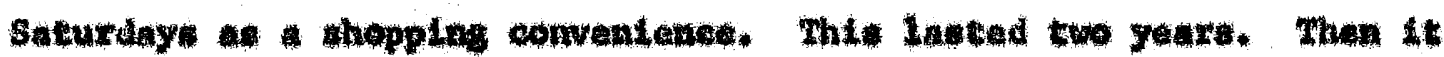
becene tourting company that tloated from place to place. The group

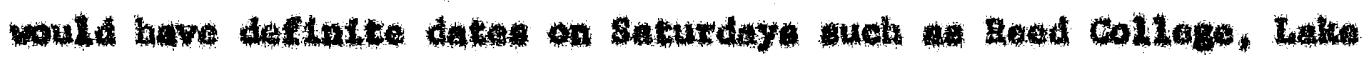

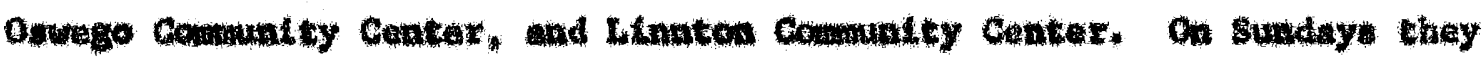

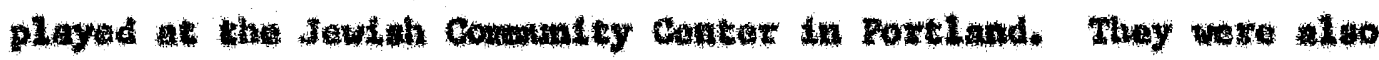
avallable for chilares's partice on requeat. This touring company of

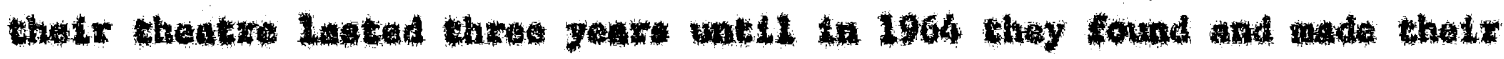

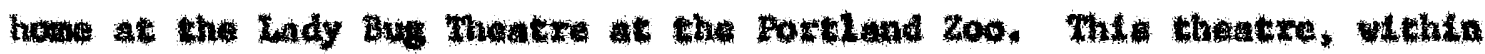
the grounds of the woo, is in the round shape of a "1adybug" and has 


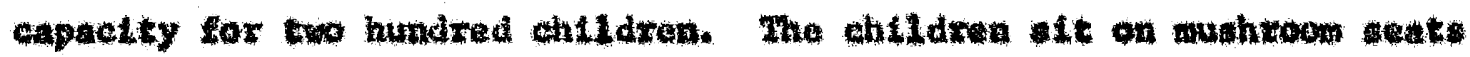

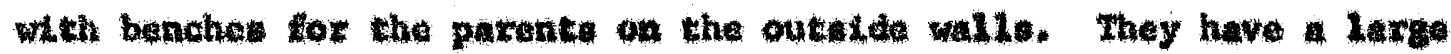
atage at the front of the budifing wad huve created all puppot theatre at the back. Masto, parthoularty wutar playing, Le uad with

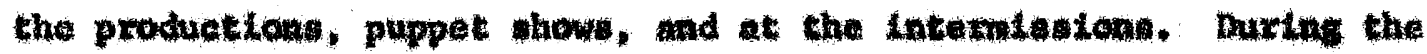

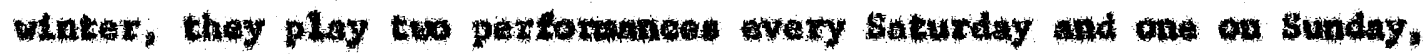
plue avery ohool hollday. Trouples to schoole, ospactally to the

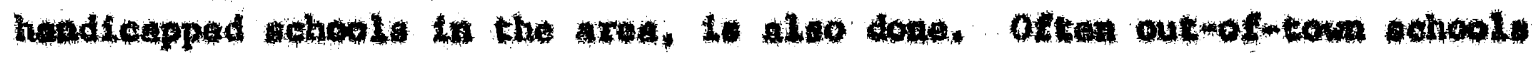

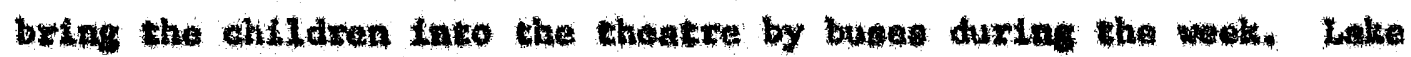

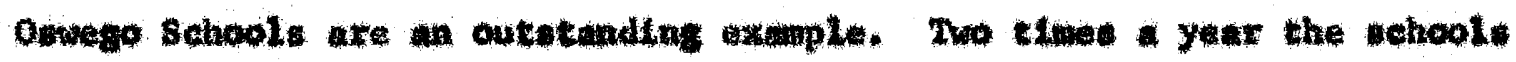

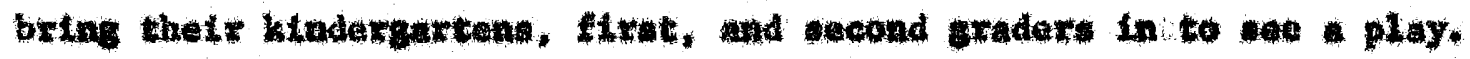

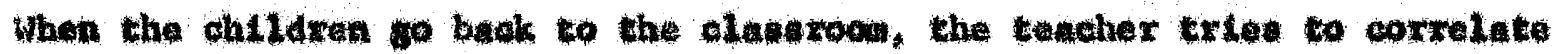

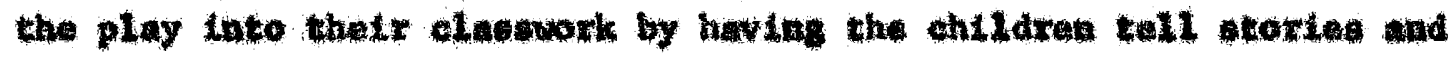

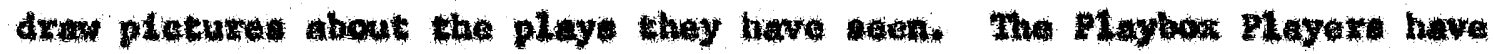

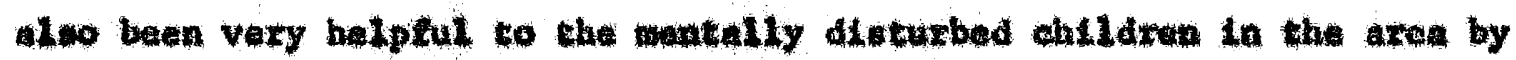

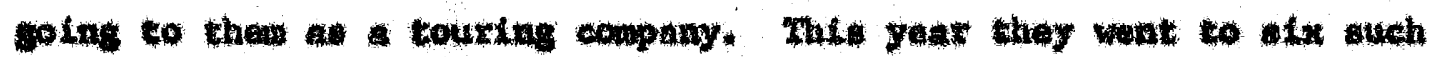

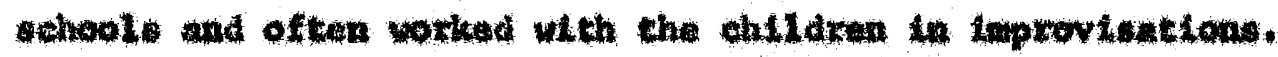

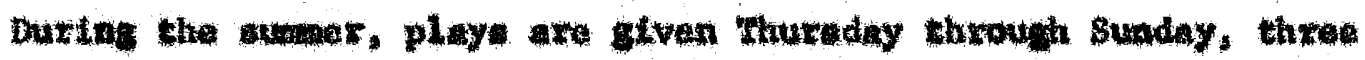

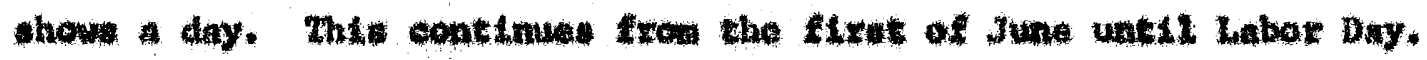

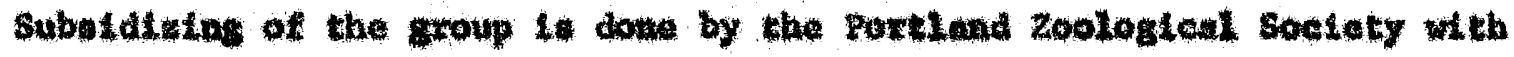
tho chudren paylus to go to the noo and butng abla to anjoy the thoutre 110 on the ande thelet.

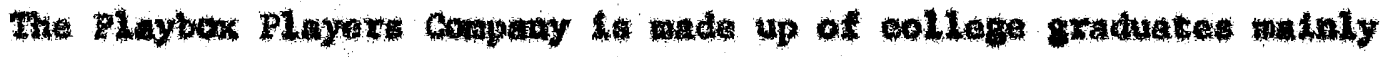

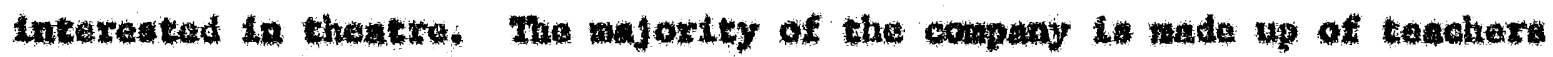




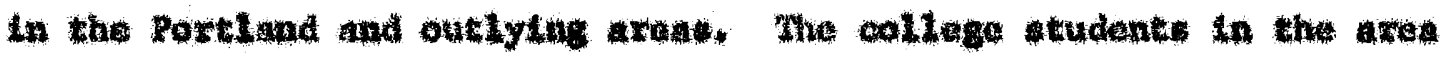

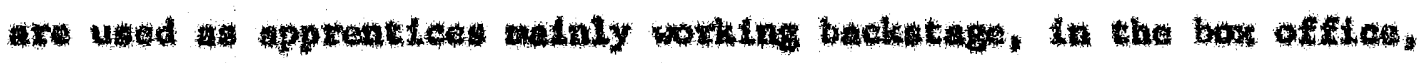

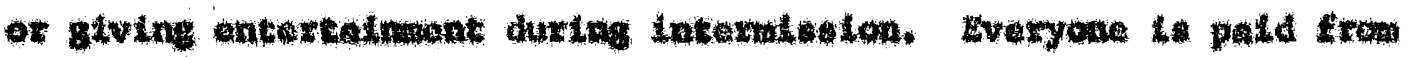

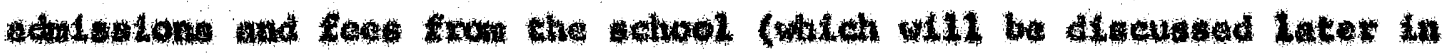

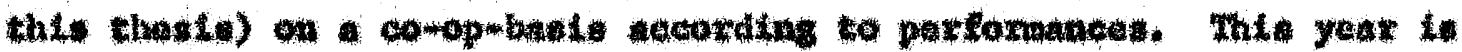

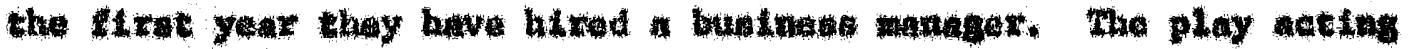

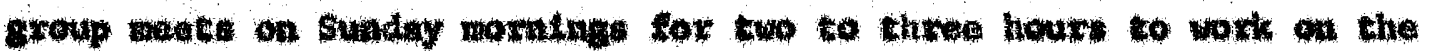

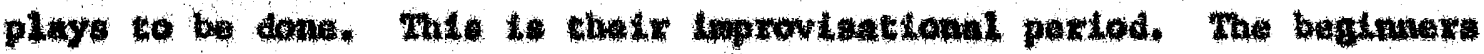

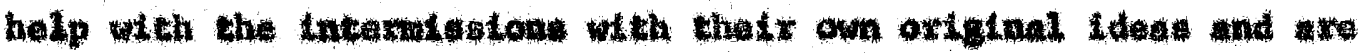

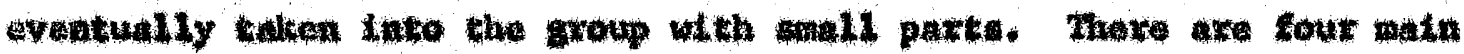

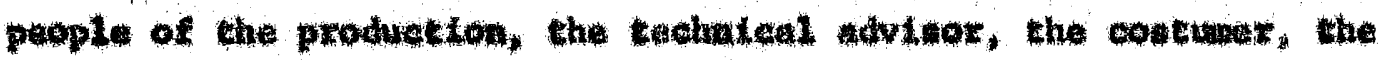

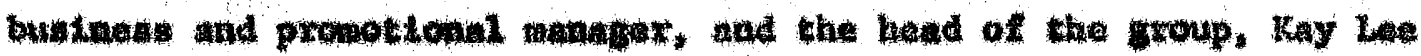

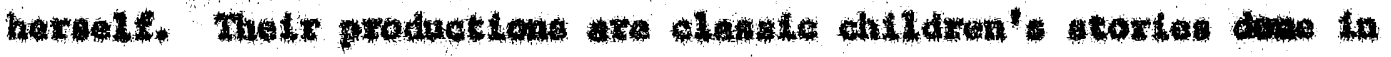

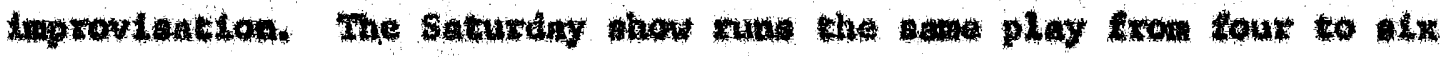

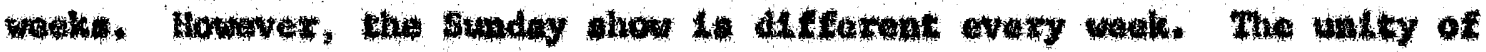

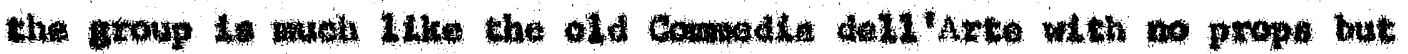

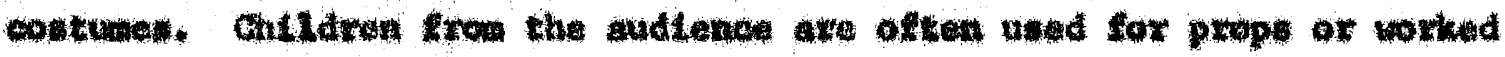

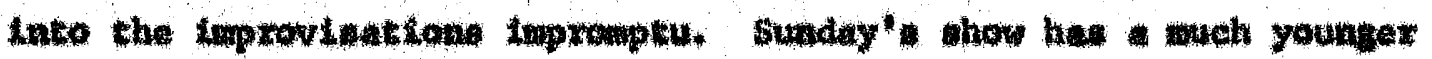

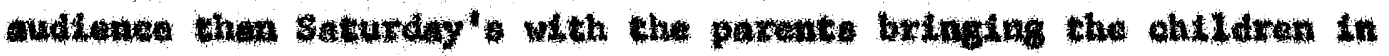

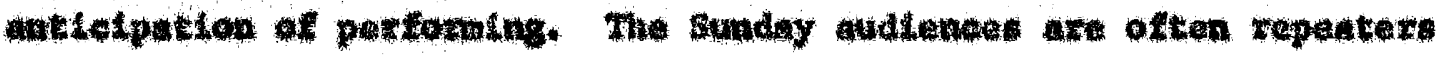
that enfoy the partuctpation tn the play wethng with the wetorg. once a

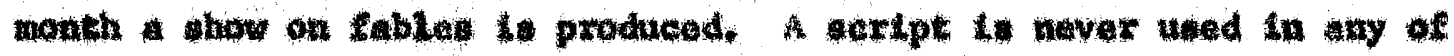

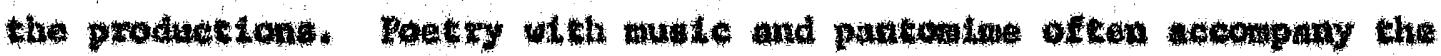
Aable progran: 


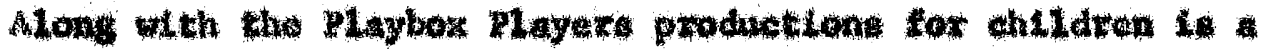

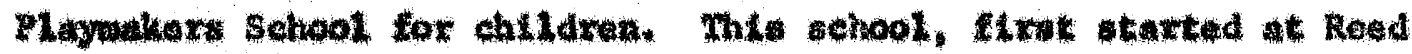

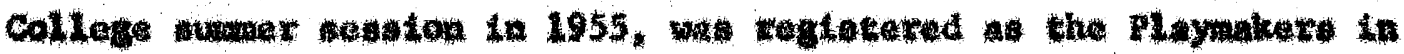

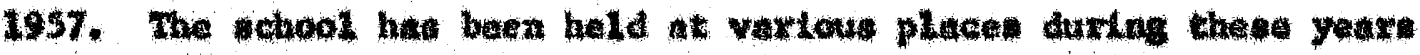
Ineluding the old Guble school, GatMin sehool, wad st. Helen' Hall.

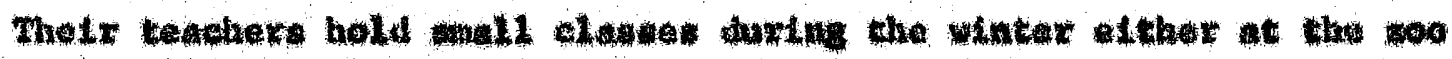

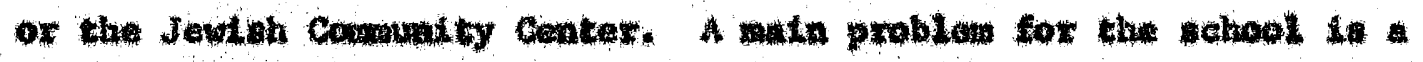

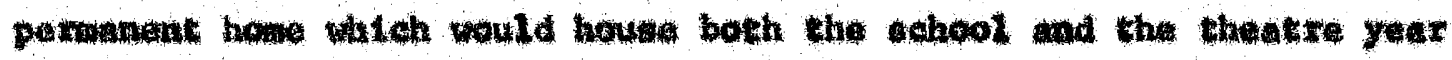

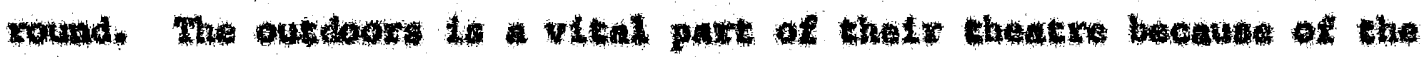

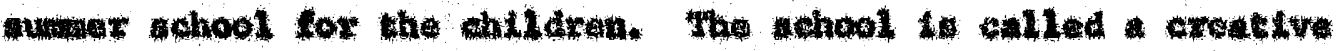

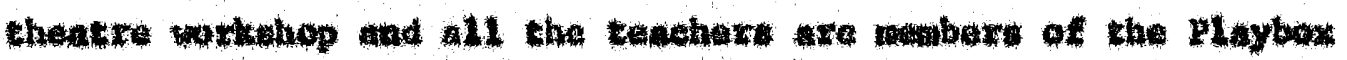

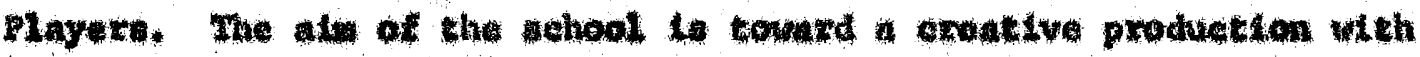

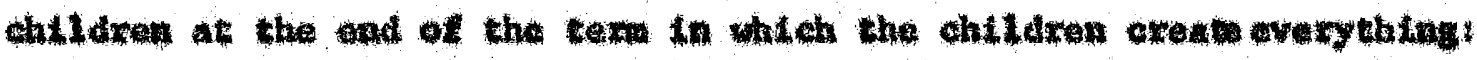

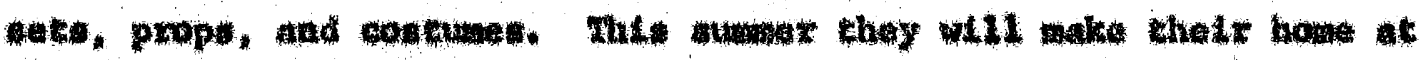

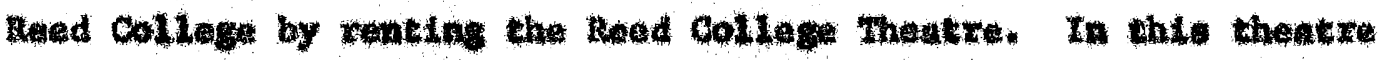

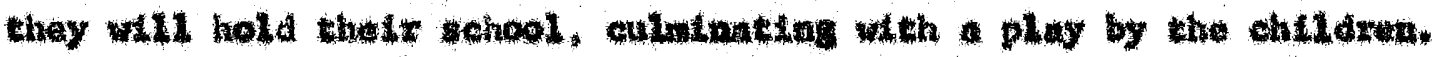

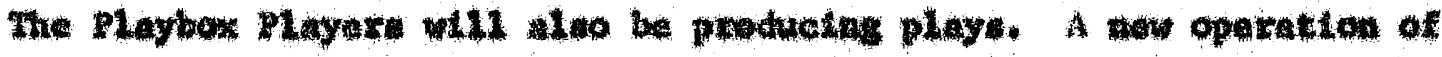

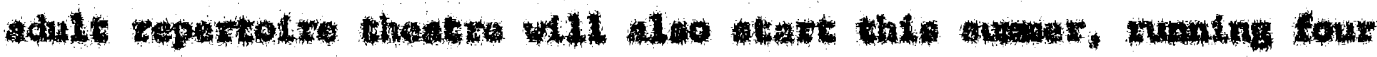
arating

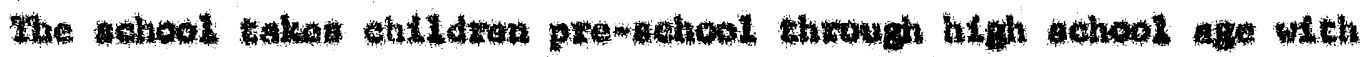

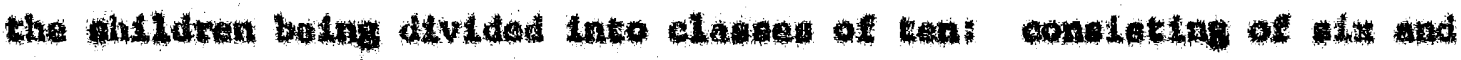

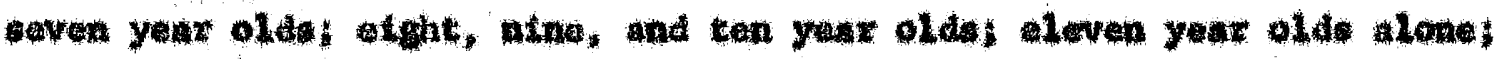

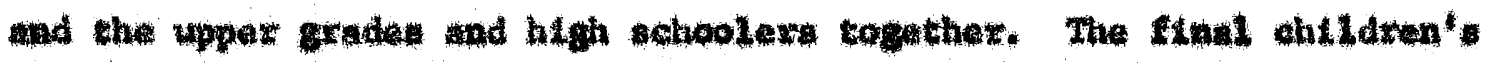

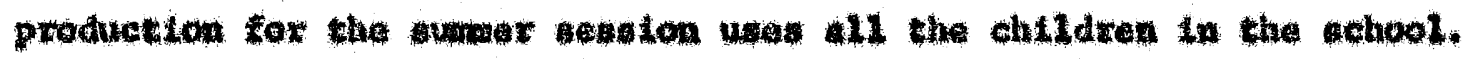


Each day at the summer session starts with a short staff meeting to plan the day so the children are allowed to work at their own ability and speed. The classes include work in dance, art, pantomime, acting, and music. Every teacher is adept in more than one fleld: acting, teaching, directing, technical work, etc. The classes run Monday through Saturday from 9:30 in the morning until one o'clock in the afternoon.

In speaking to Miss Lee, in the Lnterview, one can see why this theatre has developed so quickly in such a few short years. ${ }^{31}$ she is an effervescent and exclted young woman about her theatre and well she might be. This theatre is doing exciting things with and for children. The most important thing to her are the possibilities yet to be done In her school, bullt entirely on creative drama. Miss Lee has seen great value in working with and for the handicapped children through the years. She is especially proud of the sense of trituph and reward the participants in the program receive from doing creative children's theatre. Hex problen still remains to enable all the children of the Portland area to see live drama. She feels this can be done only through teaching our youngsters the joy of creative drama in the schools and encouragement from the schools to see children's plays in production. She and her Playbox Players are a greht hope to children's theatre in Portland.

31 Interview with MLss Kay Lee, Director of Playbox Players, May 15, 1967. 


\section{Jawidh Camatulty Contex}

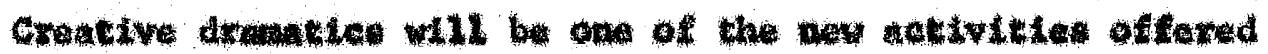

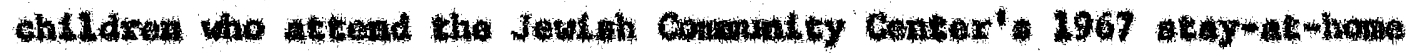

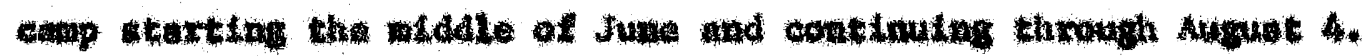

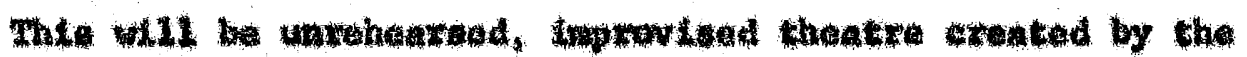

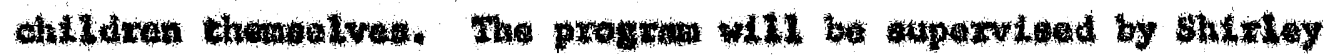

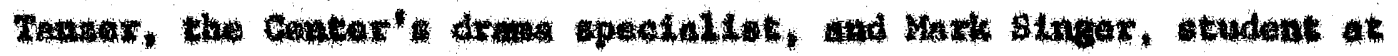

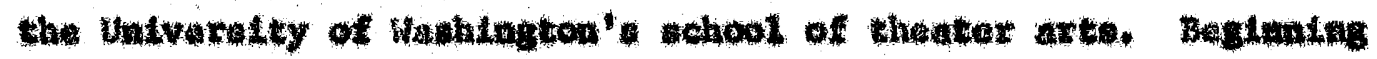

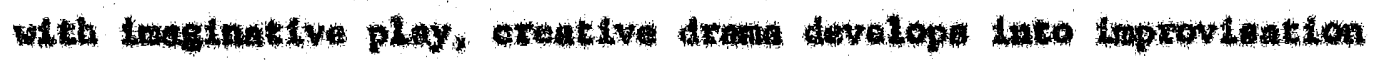

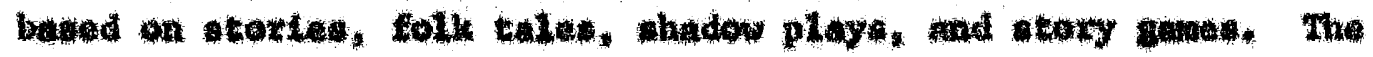

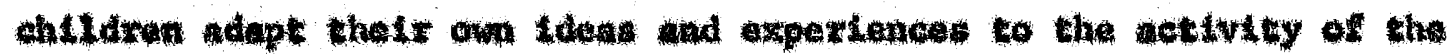
group.

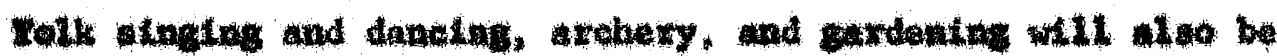

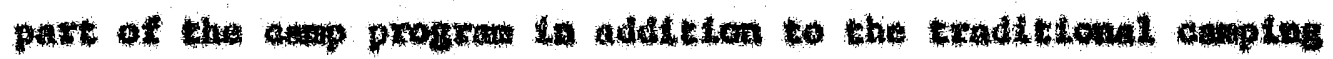

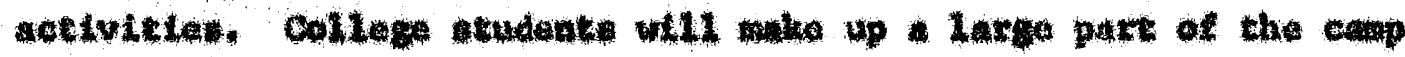

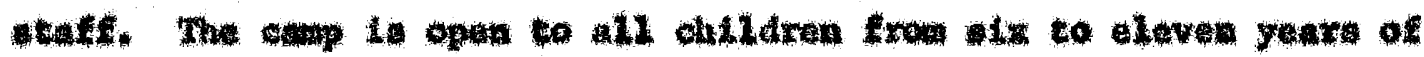
ason. 


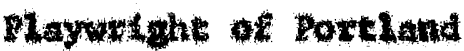

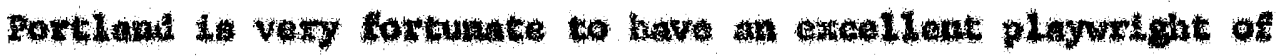

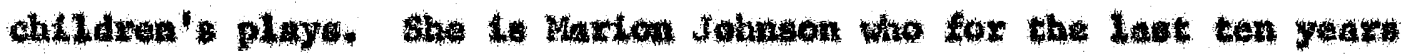

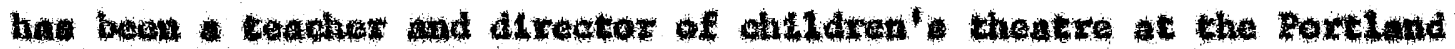

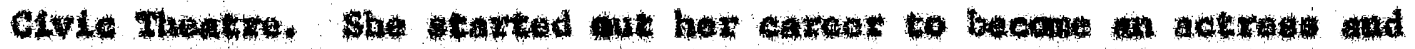

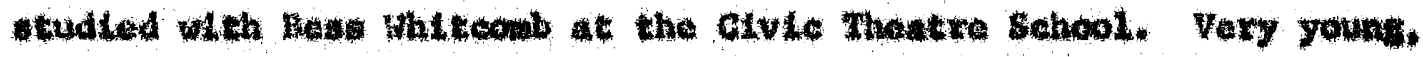

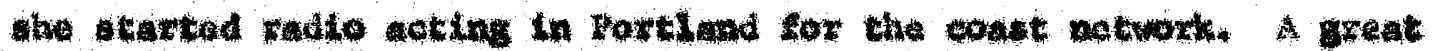
dad of ezedut ohs give to bex huband tor the background he gave her

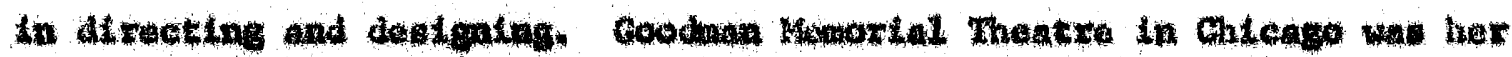

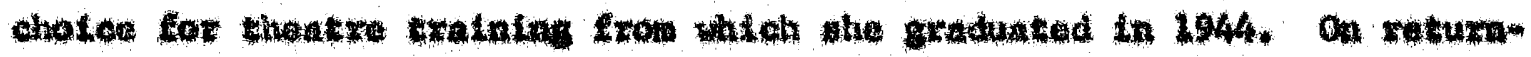

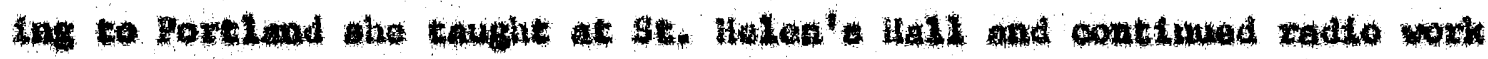

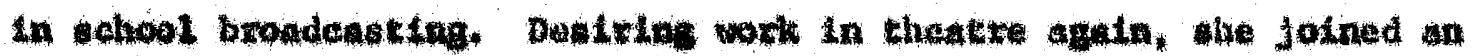

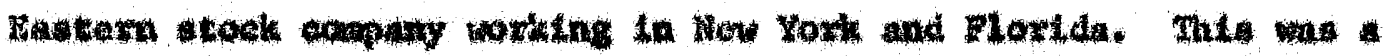

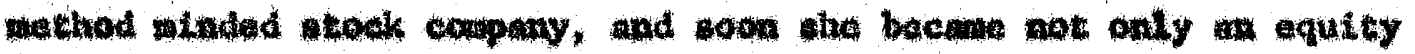

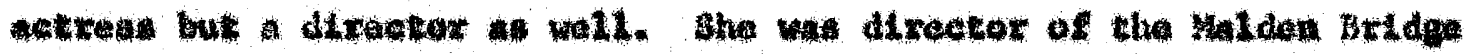

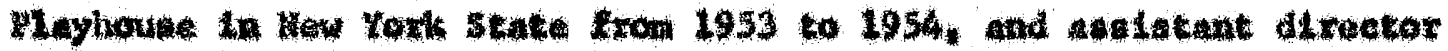

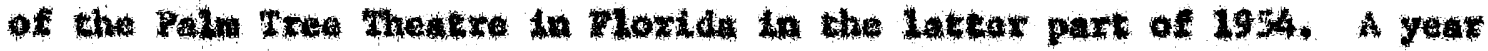

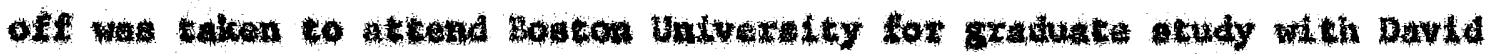

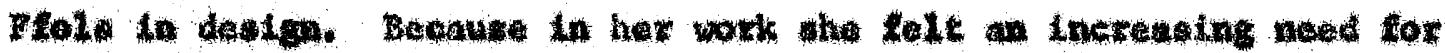

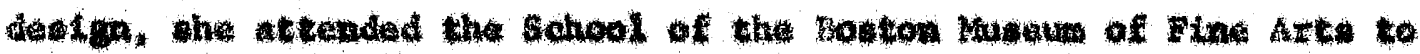
contrue hat andy. 


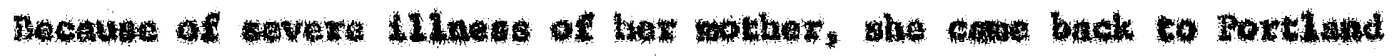

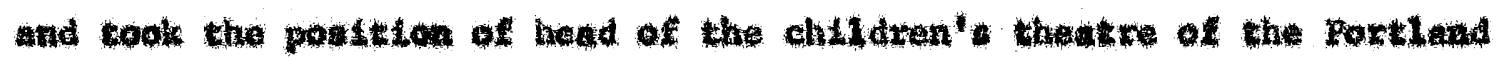

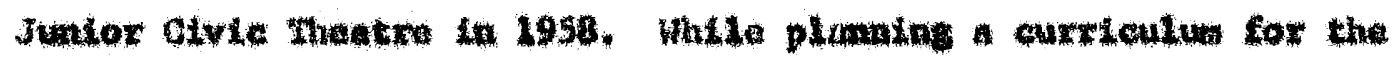

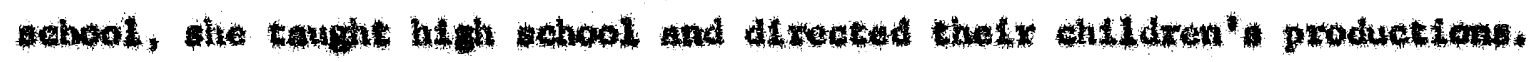

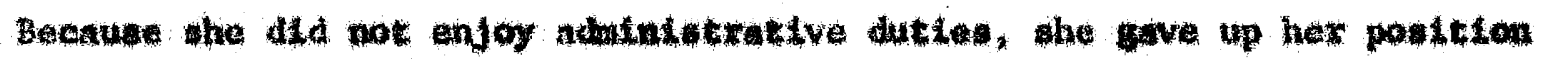
at dean of the schopl but continuted on an teachar and drector of playn.

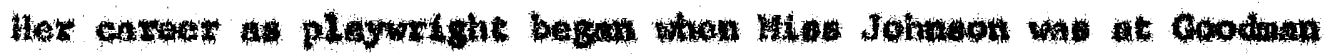

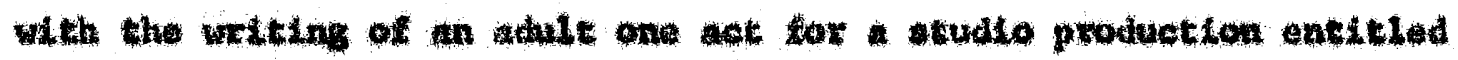

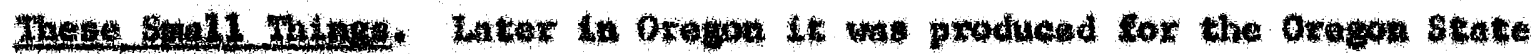

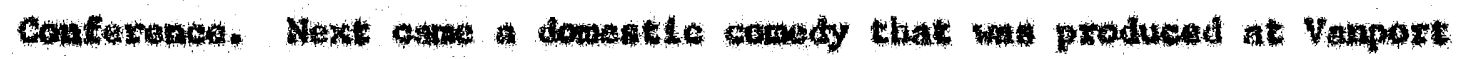

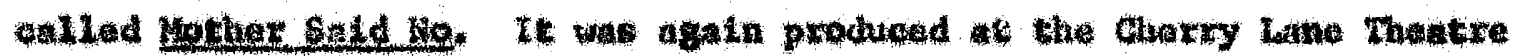

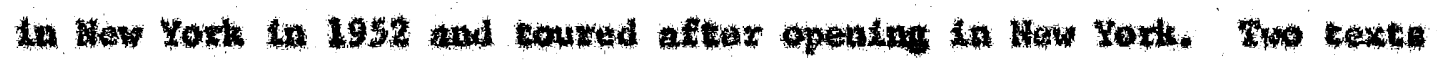

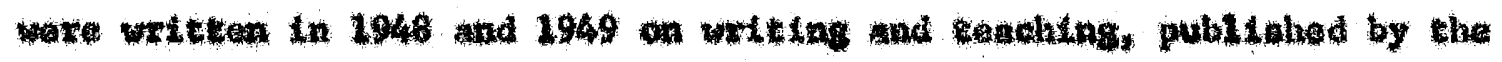

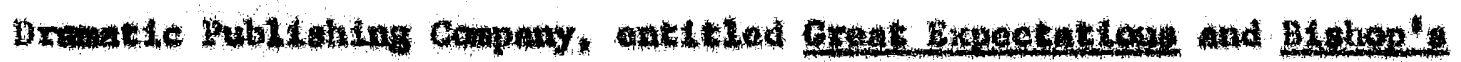
Mente.

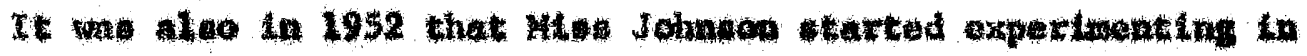

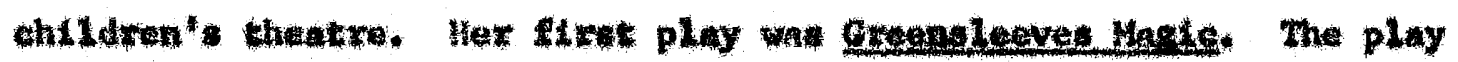

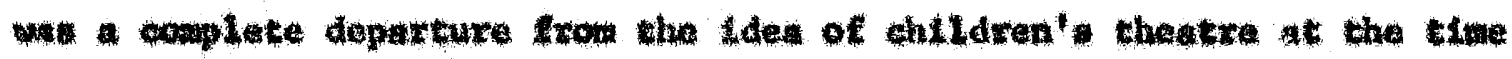

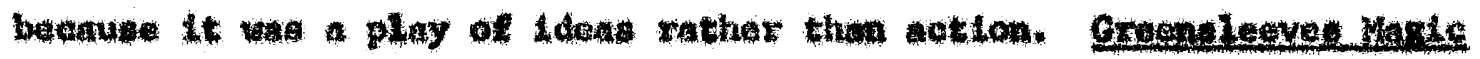

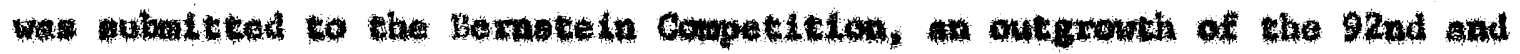

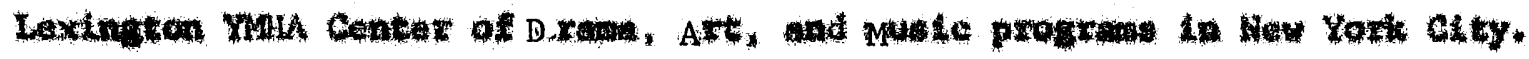

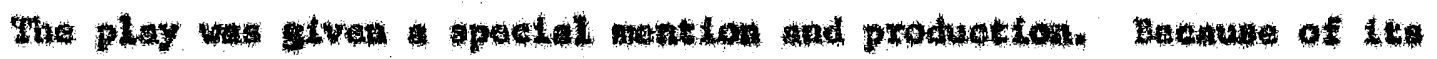

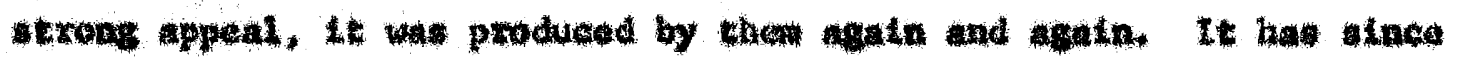

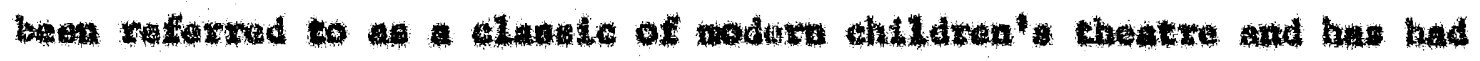

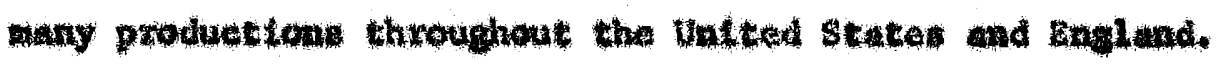




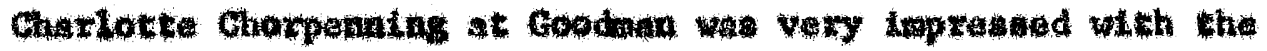

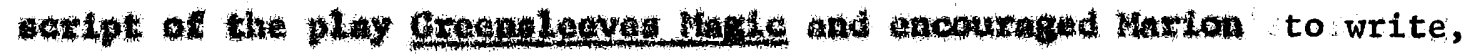

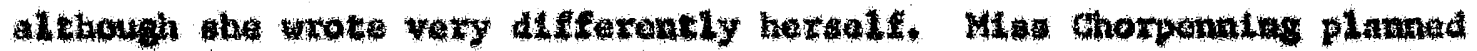

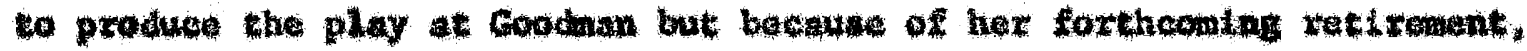

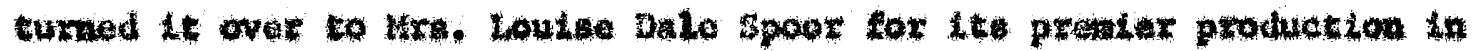

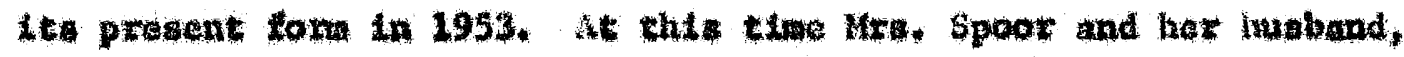

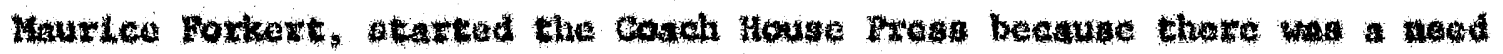

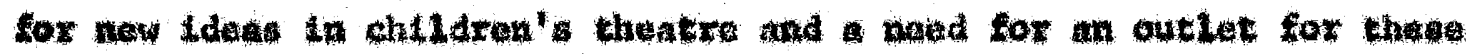

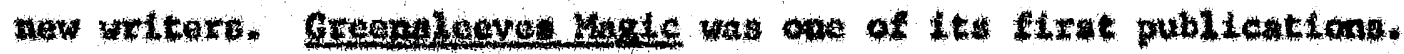
subsequatly, it wat producad around the country and dowe at the civie theatre in Portland in 1954.

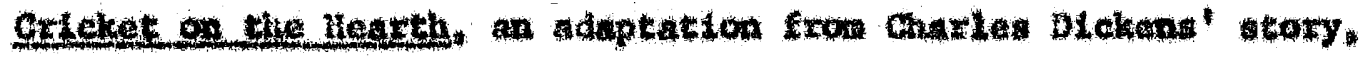

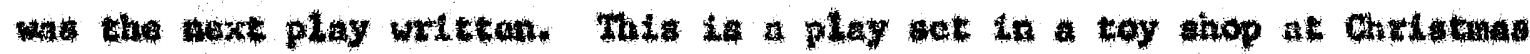

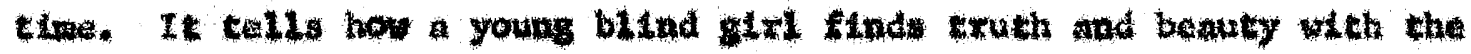

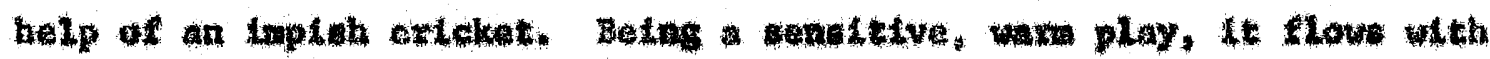

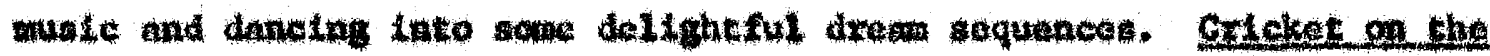
Hearth had fto preater production at Oberlis colloge in the Mil -

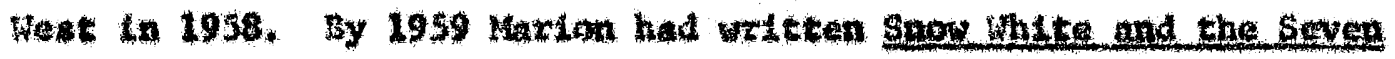

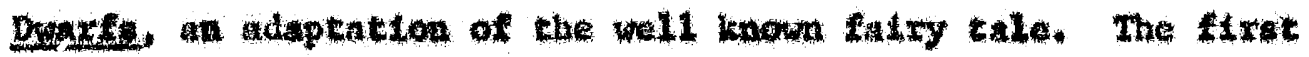

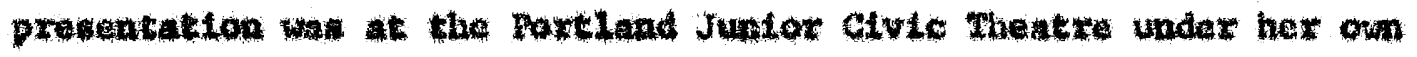

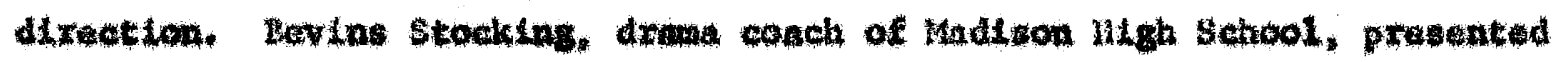

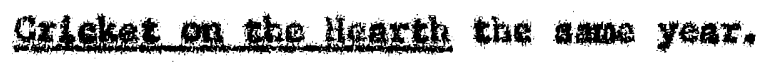

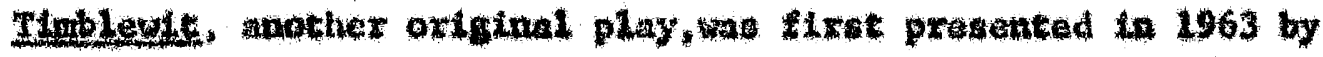

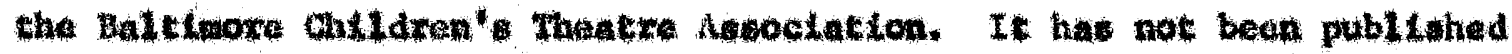

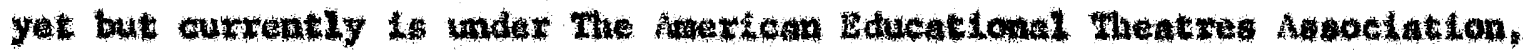
new playe department. 


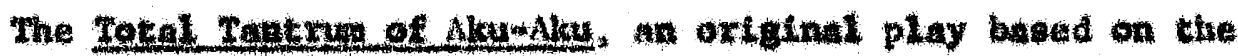

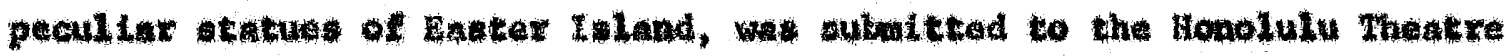

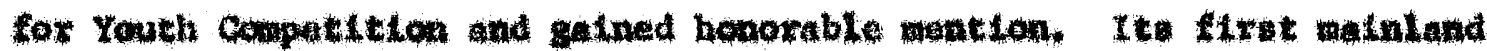

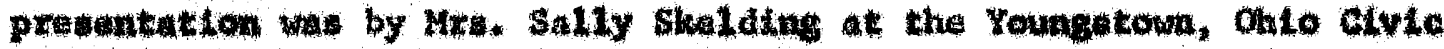
Juntor thencto in hovenber, 1956.

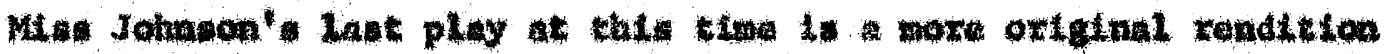

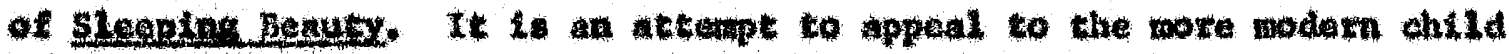

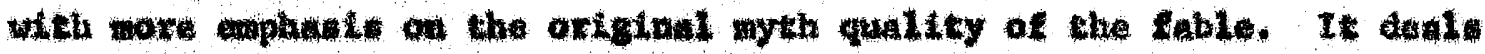

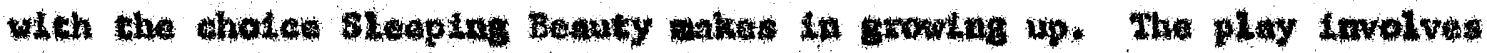

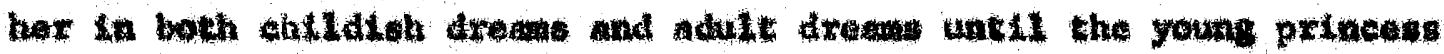

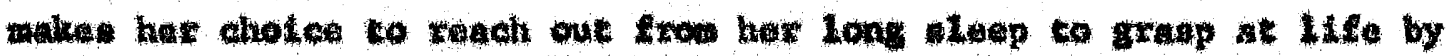

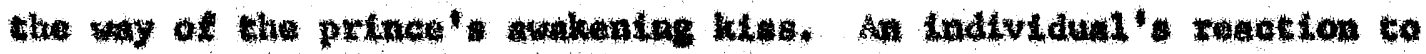

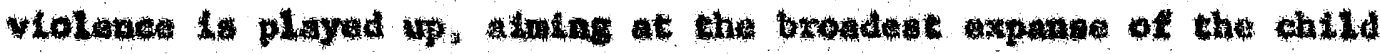

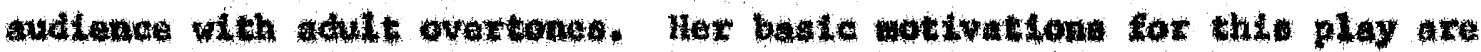

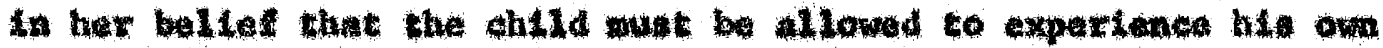

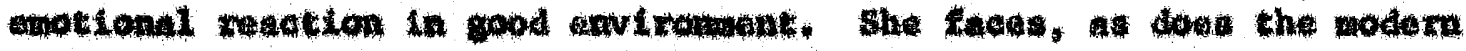

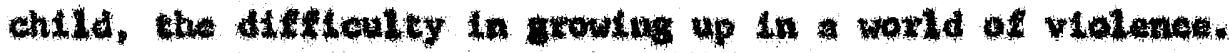

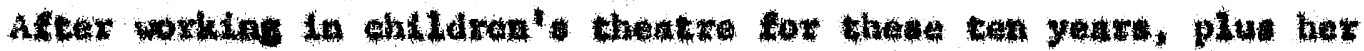

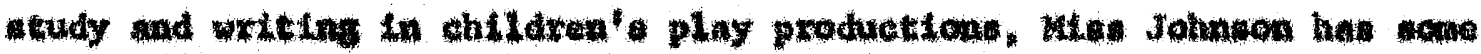

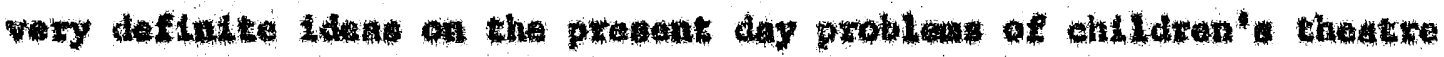

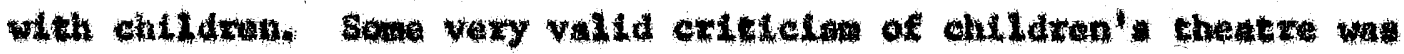

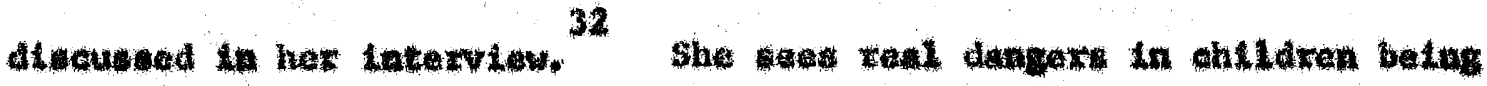

$$
32
$$
1967.

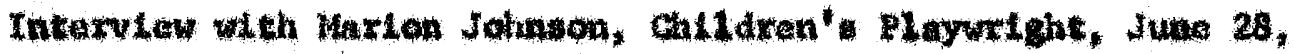




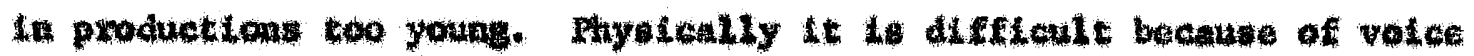
atrata plus atrain on tha nervous oystem of he youngeter boing forced betore the pullte too soon. A theter af chlldren' productions must not only ba responstale to the audience but rebponstble to the

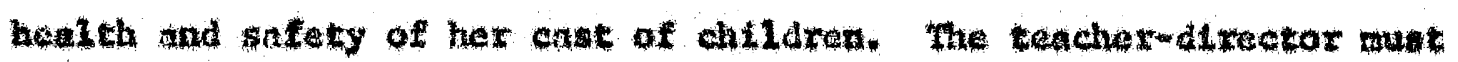

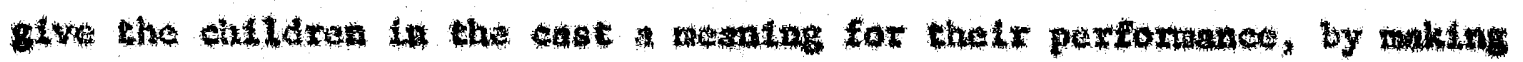

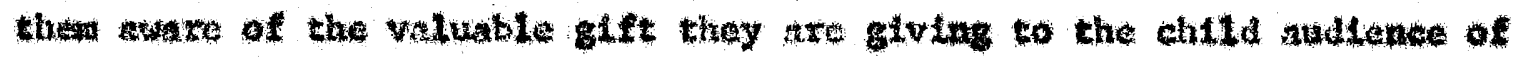
A Lve play in pexformace, Playe for chlidren mut not bust dilutod

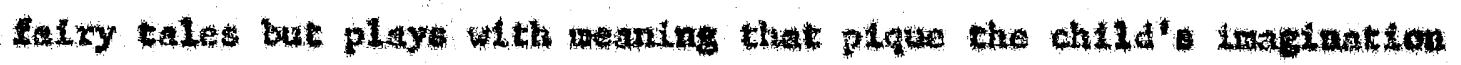

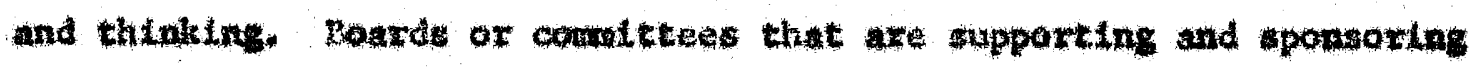

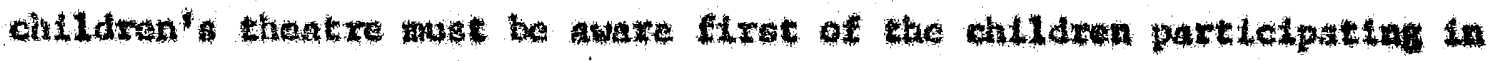

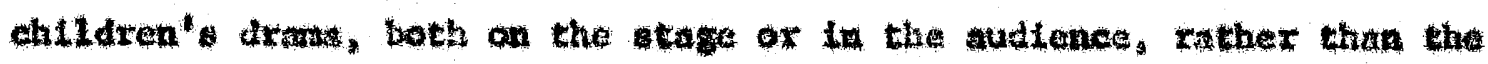

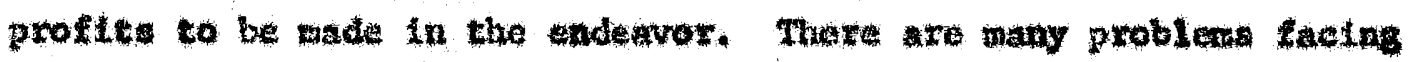

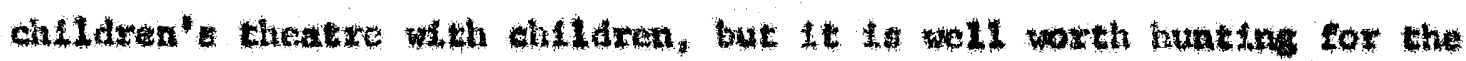
solut tone. 
BTHLIOGRATIY

Books

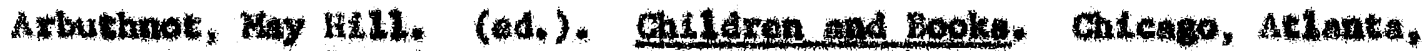

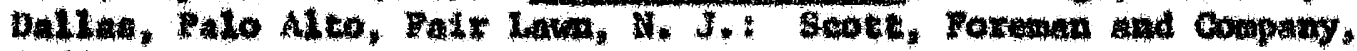
1965.

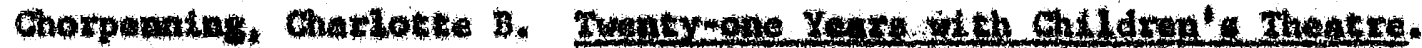

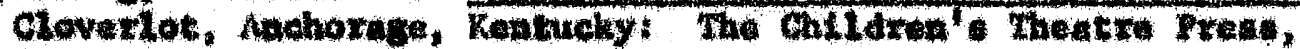
1954.

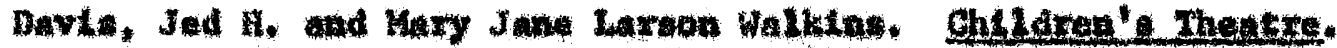

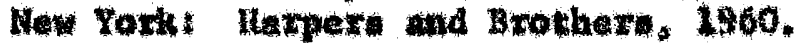

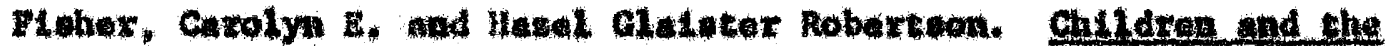

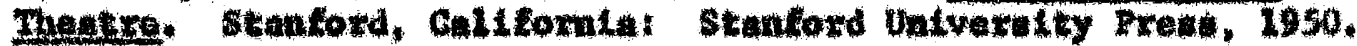

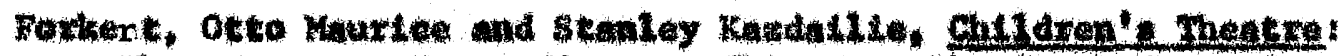

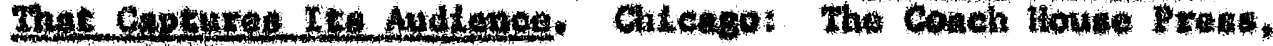
Ine., 1962.

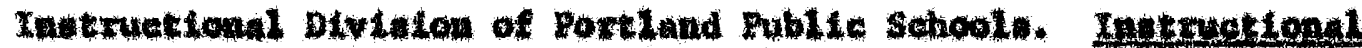
Qulda, Powtland, Oregon: 1967 .

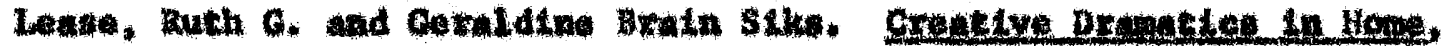

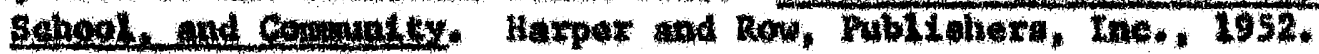

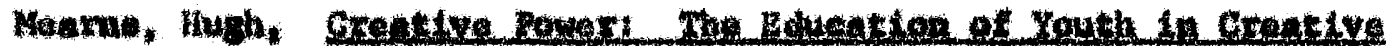

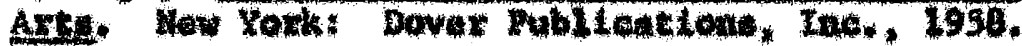

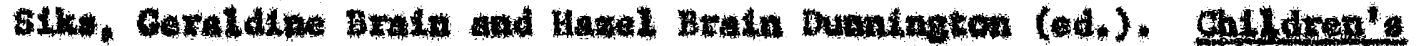

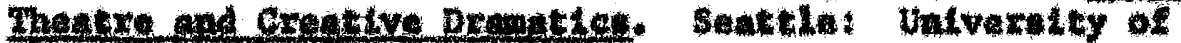
Wothlngten Preas, 1962 .

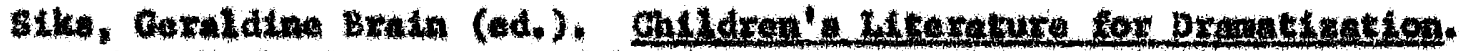

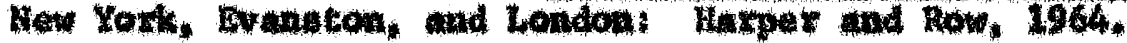

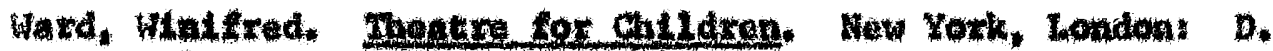
Applatonicantury 60., 1939.

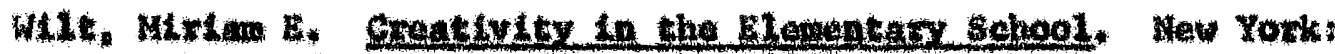
Appletoa-caneury trofte, Ine, 1959. 


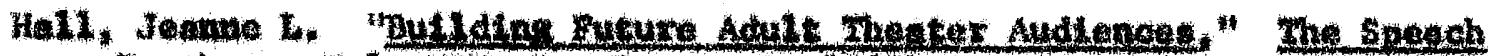
24aghes. Vol. XTV, Ho, 3, sapt. 1965).

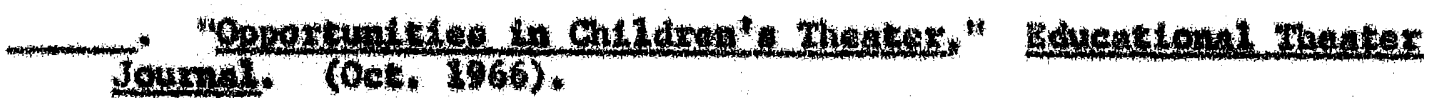

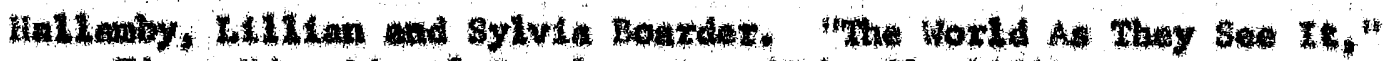

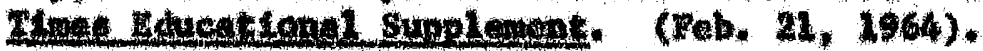

Oxencen rournal, 1967.

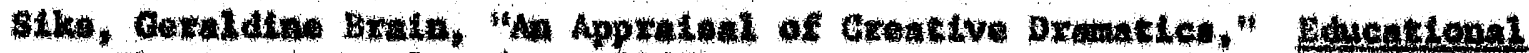

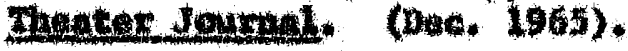

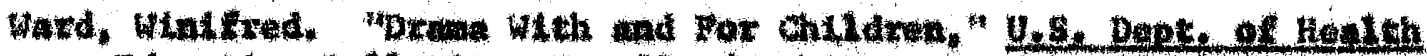

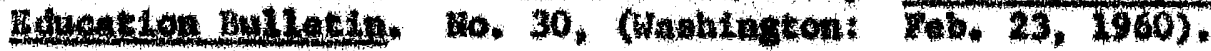

UWTULTSUED WATELAL

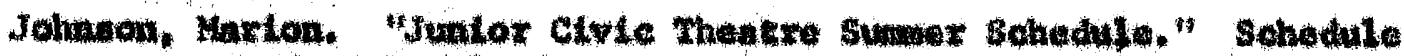

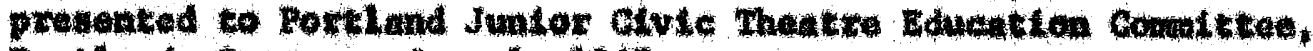
Fortlund, Oroson, June I, 1967.

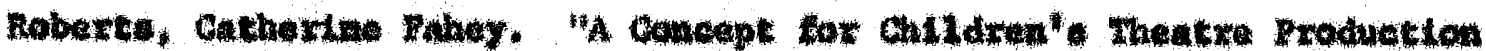

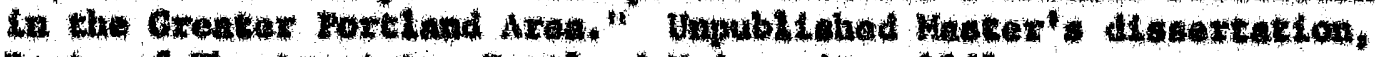

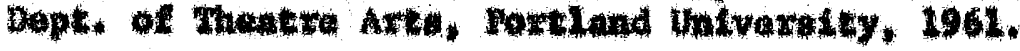

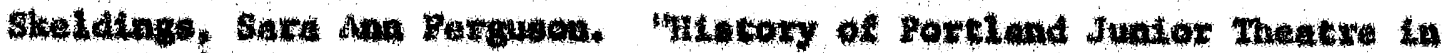

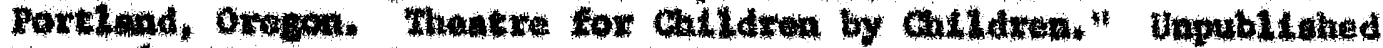

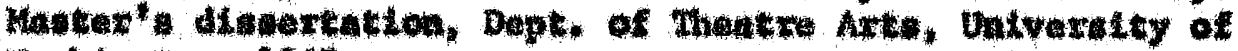
Woblangton, 1967. 
OTHER SOURCBS

Junior Clvic Thatre, Fersonal Interview wth Marion Johnson, Teacher, Director, Rottland, Oxegon. Jume, 1967.

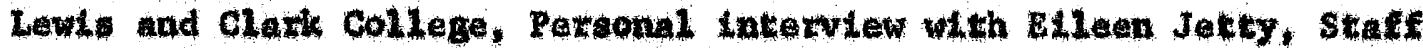
member, Theatre Arte, Rortland, Oregon. June 6, 1967.

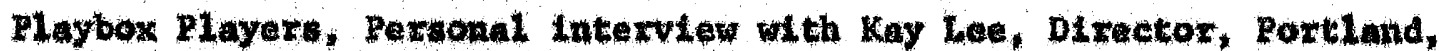
Oregon. May, 1967.

Portland Junlox League, Reroonal Intorview wh Mro, Lewis Scott, Hoard of Dtrectons, Portland, Oregon, June 19, 1967.

Portland Park Bureau, Permonal inkerview wh Drewa Dhrectore, Portland, Oregon. June, 1967.

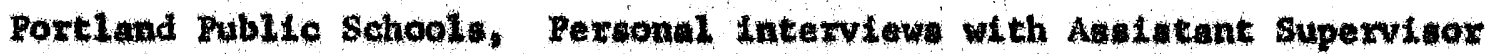
of Language Axto and grade gehool teachers. May, 1967 June, 1967.

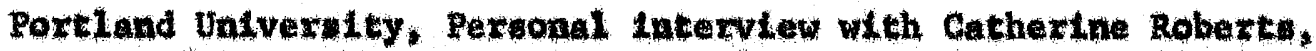
Professor, Theakre Arta. Fortland, Oregon. June 12, 1967. 
APPENDLX A 
CREATIVE DRAMATTCS AS A COLLZCE COURBE

In genewhl ereative dramatice is not a oubject in the Portiand Public school currtoulum as are mule and exeative art. In the achools it is laft to the individual tancher in the celfocontalned

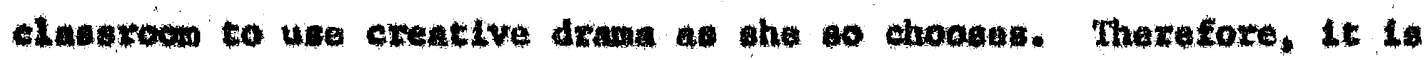
hoped that the tescher training course in the Oregon colleges and Untverattles might adopt required courae ta the teachere education

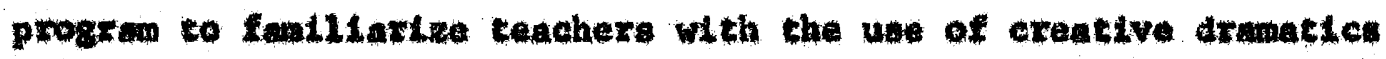
correlated with other aubject nattar bolng taught in the grader.

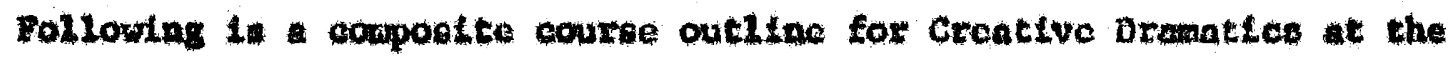
onllege level. It to a compontce doan by Richerd $\mathrm{G}$. Adoms tron various well establibhad college curricula and doveloped to for a compotte pleturia of the courae content.

Studente mojoring in creative dramatien abould be wall srounded iv theatre boekground, should be required to take courses in Introduotion to the theatre, drawatle 11terature, atory talling, and childw

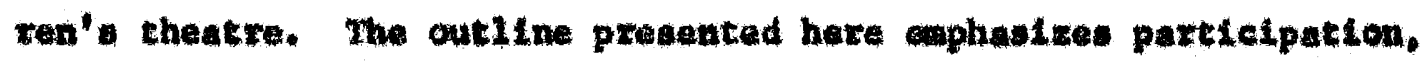
diecus ton and maluation.

1. Lecture: Ueually with participation by gtudente in creative drasatice and wh obwervation of children" elaspas.

II. Text: Veually required: athar one of coveral excellent atundard book on creative dramaties and asstgned articles or chapters from recent publications. 
IIf. Adufmoente: Uaually two of nore of the followtag:

A. Obeonvation of weakly demonetratlone wth chlldres by the inetructor or othex approved lader, watten and oral reports of observations lacluding malyefe of group, dramicie content of literature, and gutiance teelnitgues.

B. Ragular wokly asolgned reading in children' 14terature wh card-reporte of andyeis of dxematic content and ppol to ata-level.

C. Laborntory projact in gulding group of chlldren or nomer of clabe in beghning creative dramattes expertences.

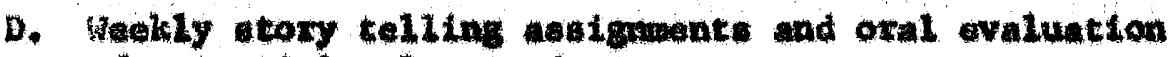
of potential values and uses.

B. Tem reports outaide raadinge, in the theld.

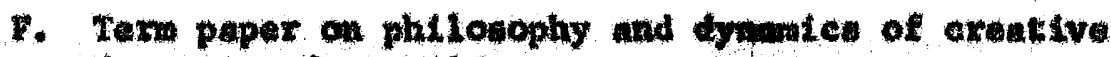
dranatle for ohlidren.

Rapresentative Outline of courae

I. Introduction to Creative Drentede

A. Datinition, nature, and philoegphy.

1. Hatory of theatre atth tophost on the relation of theatre with chlidren to tho maln atrowms of dramite art.

c. Dafintitos and interpretation of related tenas.

D. Objoctives and purpoes of cxedtive drematica.

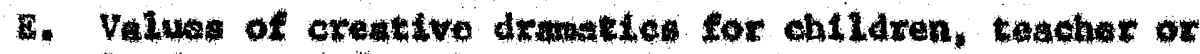
loador, and for the comanting and cowntry.

7. Application of educational princtples to creative drana.

G. Requiremont of creative dramales leader.

11. Drem an art:

A. In the achool arriculum (1anguage arts and 14terature, abeial studien, incegrated studlea, choral reading). 
1I. Introductlon to Babic Gutaned Techntque:

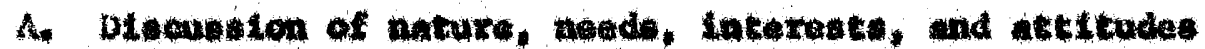

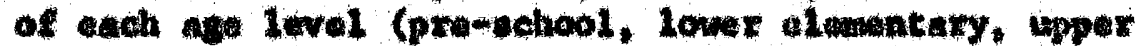
lenantary, juntor high ohool).

B. Dteoudeton and paxtielpation in druatie pley (aotivetion

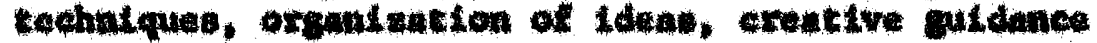
techandques).

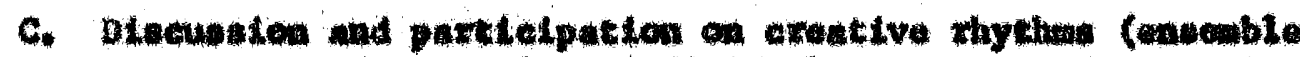

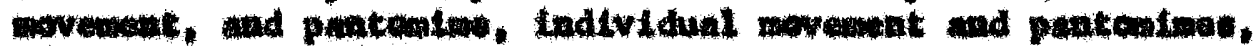
exploring mule mutartels).

IV. Introductien to crentive Culdance Teehalqute in story Brmatereten

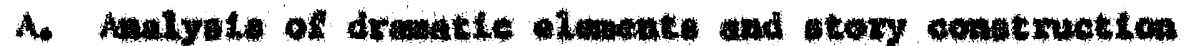

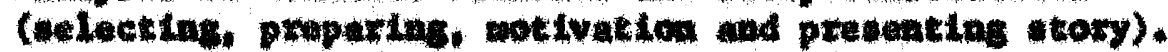

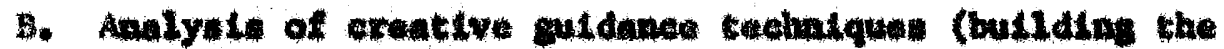

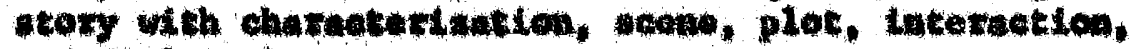
and alatogue).

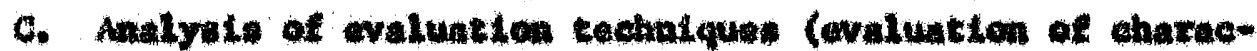

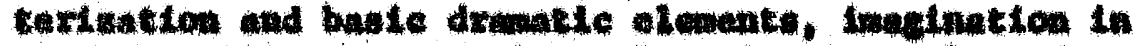

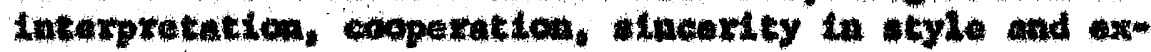
prasulati).

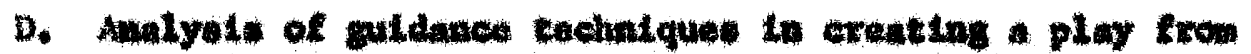
anche otory.

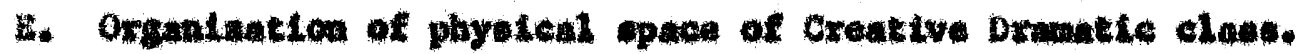

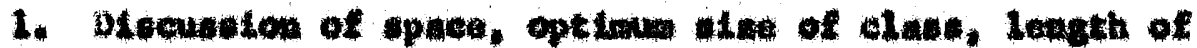

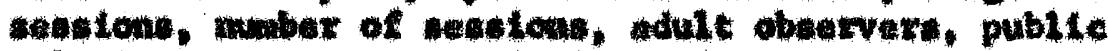
relations, and parent education. 
$y$

APPEADIX 
CREATIVE DRAMATICS IMECRATED TWTO THE PORTLAND

WURLIC LERMENARY SCHCOL CURRICULUM

Wh the help of the indruethonal guide preatated to the Portland Henentary and Ifgh Sehools by the Inatruettonal Diviston of the Portland fublic sehoolo, I have tried to correlate exeative drana into the coaching prograx set up by then. Included in this curriculum are Language Arte, Sctences, Soetal studter, Allied Axto (muale and arts and exafts) and lealth. $t$ have divided the learaing groups inco three

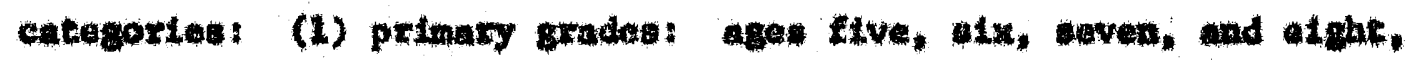
(2) widlla grades: ages nine, ton, end elevan, (3) the upper grudes: agev twalve and thirteen. At the and of each age level presentad I huve gtven briet liat of ragding atextal at that grade lavel adaptable for creative dranatics. Howewer, there is ap aluadance of material to be wed wthin the reading materials of the speciflo subject that adapt: Iteall to drematic play.

1. KLndargarten and Prtany grades :

A. Relating creacive drem to the Language Arte progran:

1. Speech: oral communiention

a. Sharing of poetry and atortev

b. Actins out nutsery thymen and atorien in groups

2. L1etaing:

a. Nojoylag stoxites read by the teacher

b. Clans diecusatng stontes by the clase

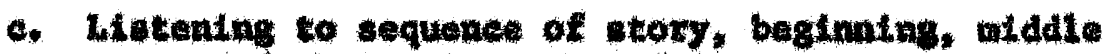
and ind (making plays that follow the ane sequance) 
3. Crative tritug:

a. Writing of play by teacher that children make up from on expertences

b. Wuting of plays by tacher from reading material

4. Meading:

a. Ohldren dranatimleg ow atorion in readex

b. Calldxen drematizing stortes read to thos

1. Watating croative dran to the soctal studte Progras:

1. Imadiate unvitoment: Kondargarten

a. Maying hoube characterication of mother, dad, brothere, and Ltatro

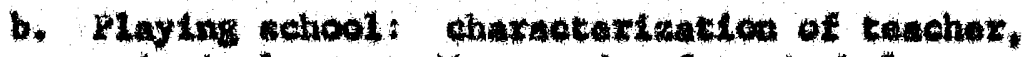
prtactpol. oustodian, and catoteria helpars

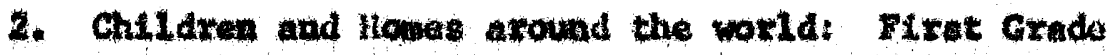

a. Making ap storles about howe 14fe

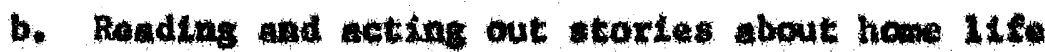

3. Nelghborhood and Gomunity: Second Crade

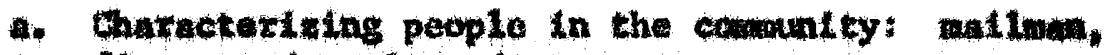
tireman, drugghet, doetor

b. Improvlsting stortas about people in eamuntty

4. Entrowental influences of communtoy life and grovth: Thind Grade

a. glay-aking and characterieation of poople in the atcy gowenuabet

b. Aoting out storien on how the elty grew and developed

C. Rolatins ereative drand in the setence Progren

1. Nathoraties:

a. Playing stowe, post office, achool 
b. Hakting une of practical applieation of wath princtples in play activities

2. Solance:

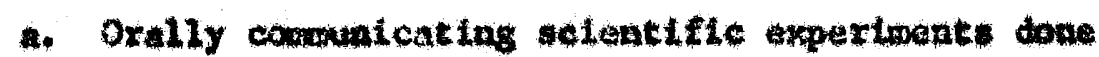
in olvis of at howe

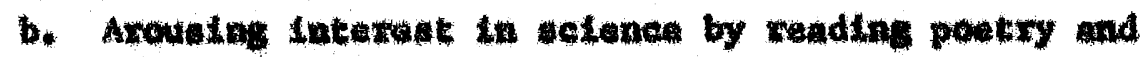
proes of natcure

c. Actins out tha wovenent of the lewents: ratn, anow/ and whd eorraliated with mute

D. Relating croutive drama in the Health and safoty Rogran:

1. Rersonal health:

a. Laaming about hath hables by actma out gattins ready for cehool, eting breakfast, golng to bed

b. Playmakins by groups on haslth habits

2. Communtty laulth:

a. Dlaymaking of going to the murat, dentiat, docter

b. Leaming how cowanit ty halpers woxk, charnetext zation of helperti

3. Salte Lutng:

a. Play-acting hone safety

b. May-anting school satety

4. Mental bealth:

4. Ploj-acting her to crat othere

b. Play-acting how to get alous wth other poople

2. Ralatug eroutive dran in the Melated Arte:

1. Mutie:

a. Listoning to muste and lettlug wownont and anod of wusic dictate movent in clases

b. Making up storlos to mute 
2. Arts and Crafts:

a. Making properties to help out on play activities

b. Making puppets to help tell a story or act in a play

F. Children's 11terature adaptable to dramatization in Kindergarten and Primary grades

1. Poetry:

a. "Sing a Song of Seasons," Alice E1lison

b. "At the Seaside," Robert Louls stevenson

c. "Marching Sorg" Robert Louis Stevenson

d. "Galoshes," Rhoda Bacmeister

e. The Little Plant," Kate Louise Brown

f. "Fog," Carl Sandburg

g. "Come Little Leaves," George Cooper

h. "The Potatoe Dance," Vachel Lindsay

2. Prose:
a. "Home for a Bunny," Margaret Wise Brown
b. "The Little Flower That Never Got a Bloom," Brian R. Hubbard
c. "The Wolf and the Kids," adapted by Geraldine Brain Siks from Grimn's Fairy Tales

3. Children's Favorites:
a. "Three Billy Goats Gruff"
b. "Thxee Bears"
c. "Bremen Town-Musicians"
d. "The sleeping Beauty"
e. "Hansel and Gretel" 
II. Mddle Grodes:

A. Relating creactve druma to the Language Arts Drogman:

1. Oral Cowasulcations:

a. Contributing to group planuing of crative play

b. Tollins gtaxies

c. Naking puppet shows

2. Listening:

a. Learaiag to listan atcentively othere parfom

b. Being critleal of how play was done, ballevabillty of character, plot, timing

c. Setng auste of toptovenent in own contribution as wall as others

3. Hrteing:

a. Writelns owa plays

b. Reading wat other playwighto have witten in chLldren' 8 druma

4. Reading:

a. Aoting out playn from clate rending or in reading group

b. Acting out plays with a group from outeide rading

c. Betng arure of how important character is to the play created

D. Relating creativa drama to the soctal studios prograw

1. Hen learn to adjut and adupt to thet $x$ reglonal enviromment: Fourth Grade

a. Lewning to work togethex in commity project by wole playias

b. Crenting plays of frentier wowement, donesticution of animils, conboys and Inditas 
2. Wen learn to grow in new natlons: Flfth Grade

a. Reading and play acting bout people wo hetped bulld our natlon.

b. Playing out roles in demodratic goverment: vee of offices in class, candetees

3. Men In Hestem homiaphere: SLxth Grade

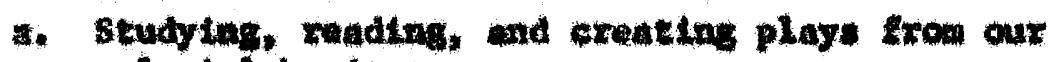
colonial horitage

b. Solving by role playing probleme of clase, comminity and nation

C. Relating creative dram to the Seiences:

1. Nathemattos using math principles in nole playing: banktng. business

2. Selence:

a. Jelng able to conmmicate orally scleathfle expertwent done for a sroup or by a group

b. Recopniating opportunitian of autdoor life to lnvetigate and bho in class activitles and play acting

D. Releting exwative druan to the Health and Satety progran:

1. Personal health: showing care of special senoos and appearance by denonstration and role playiug

2. Bawunity heelth: shoulag how individual acespt rosponatbility of commity health practiec by role playting aud creatlve play acting

3. Hental healte shoding belf-control, accapting

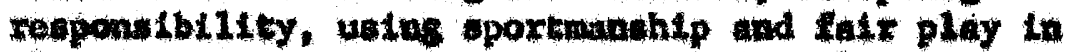
planning and organdzing group exative playe

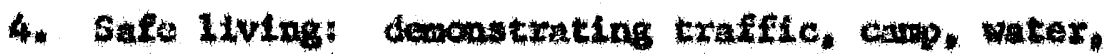
and how salety by drawatic play 
E. Relating orotetve drat in tho Rolatod Arts:

1. Muste:

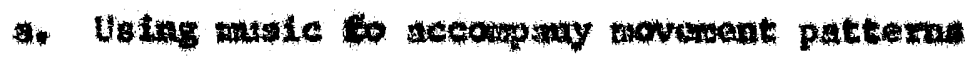

b. Walng taste to halp butla noods of plays and charadeaxtant Lou

2. Arto ad cratea:

a. Votng ant In exenctus nete to be nead in play rakting

b. UzLns art in puppetry

c. Vstng deston to crente inple costuming for play

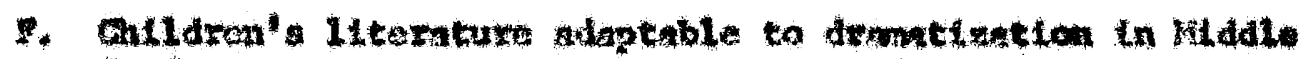
Eradea:

1. Ratixy:

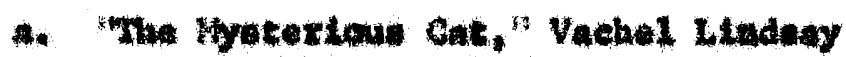

b. "Guonbound, John Graenleat mitcter

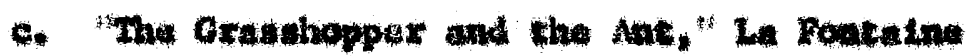

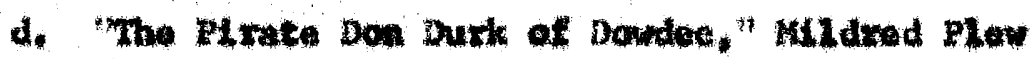
Nerryman

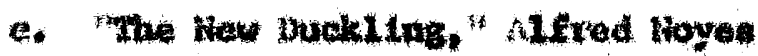

1. rumting for a Malloween Cat, vivim Mackoy

c. The king of Yallow kuttexflew, Vachal Lindany

2. Prode:

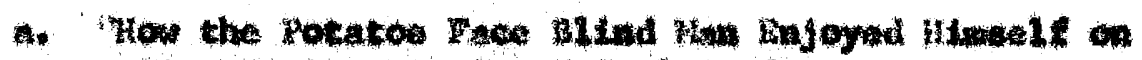
- Fine Sprins torming, Carl Sandburs

b. "Adventure in the Orchard, Itabel 5. Huxper

c. Whoo, Joul Mandlue Wareto

a. "swow thite mad Roge-Red, Maxgaret Hunt, trandation of orimo taluy tale 
- "Rapunzel," Orimmi Balry Talas

*. Ugly Duekling, "Hans Chriatien Andersen

g. "The Gxft of St. Noholac," true Halecumon

ITI. Uppor Grades:

A. Relating extative drems to the Language Art: prograw:

1. Orat cormunication:

a. Making opeoshes

b. Prepuring plays to be given to youngar ehtlaren

c. Reading poetry al ud and choral roadinge in group

2. Listening:

a. Listening and conotmuctively extcialatag othex performinces

b. Bvaluatling other performancea

c. Approchatung poetry and prose reat alond

d. Fartetpating in round table and panal Alacusatons

3. Iritingt writing thetr on creative poetry, prose, and plays

4. Reading: reading a varlety of matertals that ean bo uyed In group oral pexformances

B. Relating creativo drma to che Soclal studies progran

1. Le about the worla: Seventh Grade

a. Iuterpreting and reading plays of other countries

b. Rresenting Improvigations of different concepts in difforent countries

c. Seeing plays of other countries

2. Emargunce of a nation: Edghth Grade 
4. Solving and diecuseing atfferent natlonal problew in panols and round tubles

b. Radto and dovatoping charactontattoas

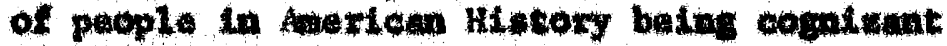
of their soparite alcuations

C. Relating creative drant the selence progran:

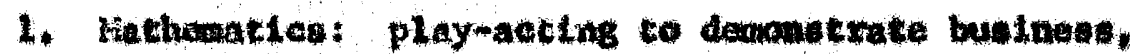

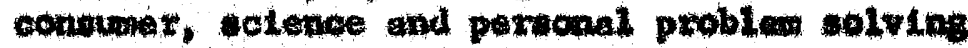

2. Setencet danongtrating salentifte invertigation orally

b. Kulating creative draw to the

1. Fergonal health: helping other through ocal proven tation of good health hablts (play, postry, stowles)

2. Gomunity halih: halptag yourger childwen by oral sominication to undetstand conmuntey health problew

3. Mantal hanlth: role playing in making frtandy, geteins along with family, doveloping ow belt-direotion

4. Safe 1iving: dowonstrating in dxanate play perwonel and mechrnioal safety, satety at school and mooldent prevantion

2. Ratating of creative drate to the Allied Arts:

1. Wuic: using wustc to onhance parfomaane of proventations

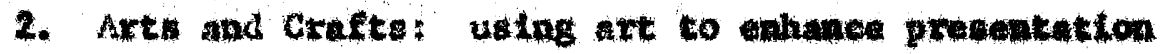

F. ChIdren's Itcerature venble in drewatidution in the Upper Crades:

1. Poetry:

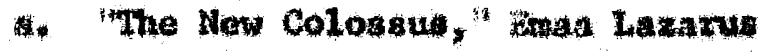

b. "Chargo of the Light Brigada," Alfred Tennyeen

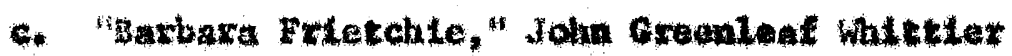


d. "Whe Croation," James weldon Johnson

e. "Sow Three Mitches," Walter do la Mare

4. "Stopplas by Woods on a Snowy Evontng," thobert rost

2. Exoset

a. The katphte of the stiver shield," Raymond Machonald Alden

b. "Jo meet Apollyn frow L4t52 domen," Loutos May Aloot

C. Prologua to the Hemx Adyenturas of pobin Hood. Howard pyle

d. Ren HLabeth Janet Gray

c. Lee and Grant at Boparatoz, Kantor Kackinley

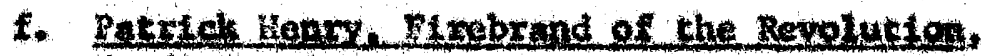
Mardi Cenpio 
SUMULX

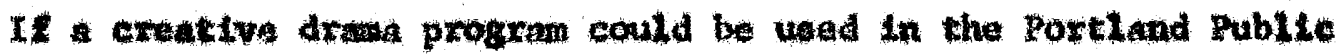
Sohools, cxeative drona should be weed exclustudy in the primary and

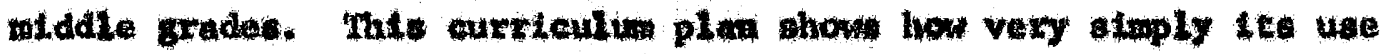
could be correlated with the regular progras wod in the gehools. Hony tenchere could expand the progran meh further by using thete ow cenchting mothods, tochntques, and matertal avallable to then. This currifulum plan how how very eacily subjects night be cwugh to wall the ehildren wh a more creative experience in thetr otudiat.

An Ideal eolution to the upper graded drame progrean would be the

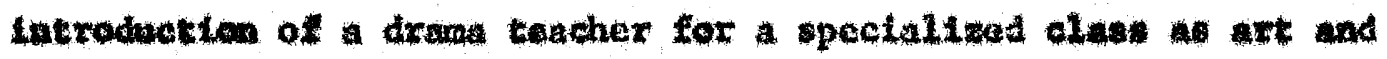
multe now bave in the buck to back progran in the Rortland public sehools. She conld dovote spectic time to more technionl theater training for her atudente whth presentation to the other chlldren in the ochool. In curriculum plan for the upper grades I have shown how

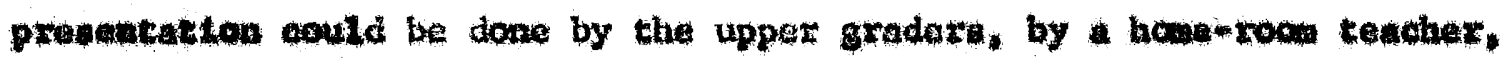
also. By this age tiey are able to handle panel discunstons, opeedas, playe fow presontation if they have had a good bakkground in creative dranutles in the Lower grades. 
Aeptonto $c$ 


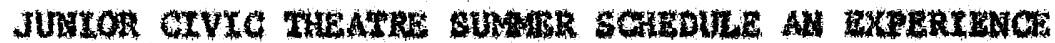 IN TOTAL THEATRE IWCLUDTW DRAMA-DANOE

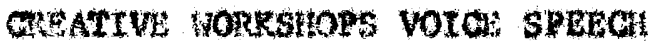

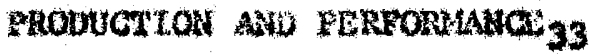

Workehope in drana-dnance for all age groups, stress to be on

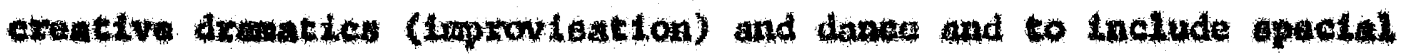
Instruction in volea-upeech cochiques. For grada one through otx

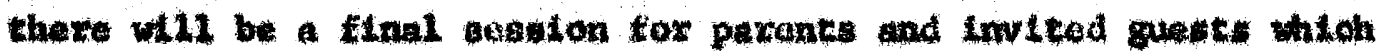
411 be alther demonatration of actual class wotk md/ar ocena or

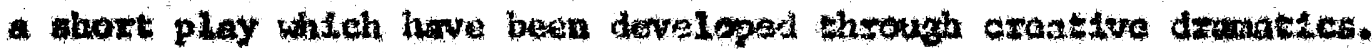

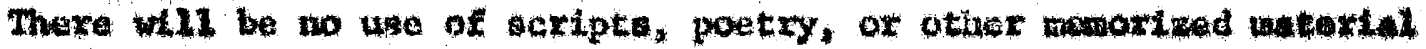

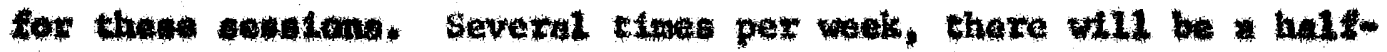
houx oeston lurting the acting period wth the volce-diction teacher and the regular clase tadeher w11 also be in atteadance wo that the work can boordinated.

A1 tudente in grades seven through high ohool and poentbly a fow wore expertensed (6th gradera) will be members of the Froduction Caupany.

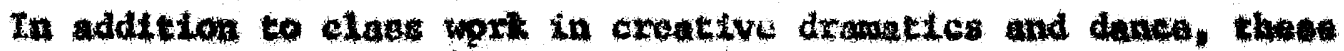
studente wil presut a full-beale production of a ch12dren" play on

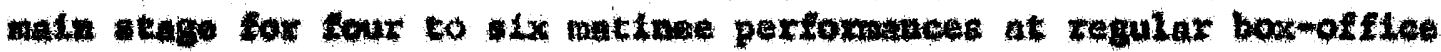
prices tor the chlldren' plays (comps to parents) and one ox mowe

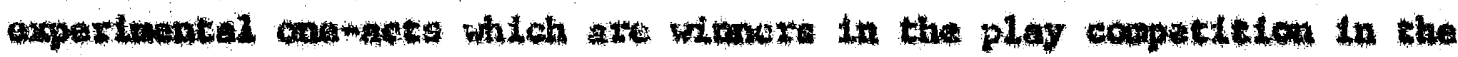

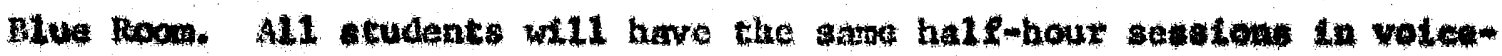

33

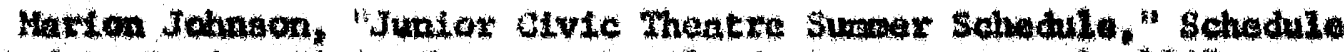
presunted to Juntor Civie Theacre, fortland, Oregon, June 1, 1967. 


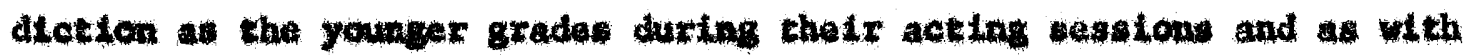
tha youngex, the regular clase seacher w11 also be presont. studentes 14 this group wil therafore be pehedulad for 45 minutas to one hour of dance (or production-fencing-optlon) one hour of acting (creative drama) and one to one and a hal hours of rehearsal. Dance for seventh and Igth grader ad hLo achool students will bo one class sinee this group will be aplit into danes and production for this houx, Actins for the praduct Lo tompary must be taught with an waraness of theatromasa-wole and to this and it will be naquired that tho duelgn and conture department bring sketchea, plans, atc, into clasis segatons for discasatom wh studente and difectors. This will also man that designe, ete. wat be planned and In the lands of the diructors by the baginning of aumex Mestion.

The class in production and fencins should be open an separate clasw to itudents wo way be interestad in this aspeot of theatre and not aeting.

comptitions flould be amounced as soon as posgible in the wool

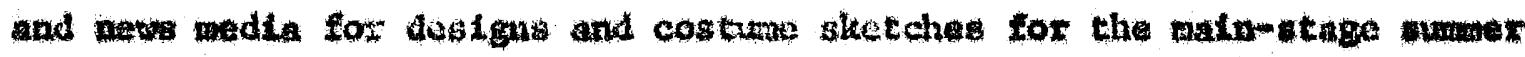
play. If cheopo a dranativation of all-knona falry tale or legend, this wil bo sioplo for then to get the story. 14 not the ocript, which

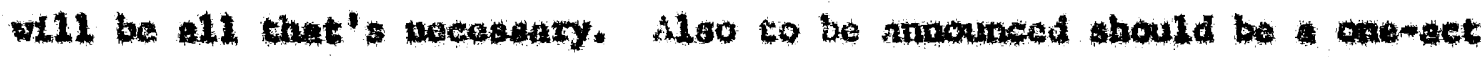
play comptitlon for high school atudonts, tho play to be ather tuen-age or adult In taterial. Pxizes emud be ten dollaro for costume and at deatgar and display th the theatro lobby and the execution of the desiga 14 posatble and $\$ 15.00$ for firot and $\$ 10.00$ for tocond prizes on the play 


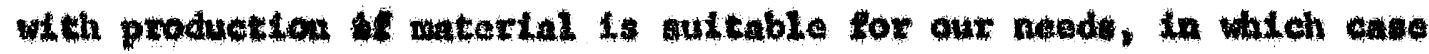
the wuthor to be preaent for rehentanls and have the opportuntey of worktny wh the diractor, geating how production worke, atc.

\section{Possible schedulting}

Thls wll wequite use of both atudios, the Blue Room and at ther, the mainstage.

\begin{tabular}{|c|c|c|c|}
\hline I24 & quss & CRos & STLSIO \\
\hline $9-10$ & $\sec \ln g$ & $1-2-3$ & 1 \\
\hline $9-10$ & Wancing & $4-5-6$ & 2 \\
\hline $10-11$ & acting & $7-8$ & Rlue Roow \\
\hline $10-11$ & $\operatorname{agctag}$ & Figh Sehool & Malnetage \\
\hline $10-12$ & neting & $4-5-6$ & 1 \\
\hline $10-11$ & baxcing & $1-2-3$ & 2 \\
\hline $11-12$ & Dancing & $7-a$ & 2 \\
\hline $11-12$ & Daneing & High School & 2 \\
\hline $11-12$ & $\begin{array}{l}\text { Production } \\
\text { Fonclng }\end{array}$ & $\begin{array}{c}7- \\
\text { HIgh Sehool }\end{array}$ & $1 \cdot 2$ \\
\hline
\end{tabular}

Volcomepeek to be on altomate days as Wonday half hour each in grade 4-6, 1-3, and 7-8 tueaday high school. 